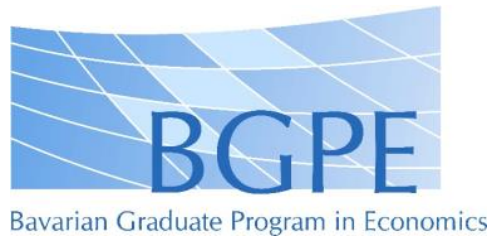

BGPE Discussion Paper

No. 172

\title{
The Unemployment Effect of Central Bank Transparency
}

\section{Christoph S. Weber}

\section{August 2017}

\section{ISSN 1863-5733}

Editor: Prof. Regina T. Riphahn, Ph.D.

Friedrich-Alexander-University Erlangen-Nuremberg (C) Christoph S. Weber 


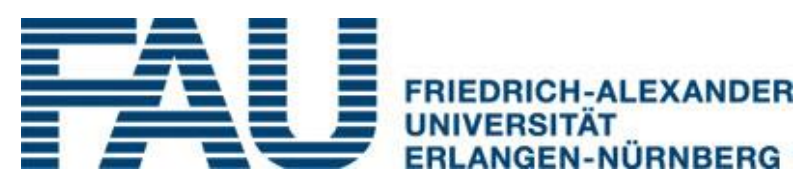

\title{
The Unemployment Effect of Central Bank Transparency
}

\author{
Christoph S. Weber*
}

\begin{abstract}
:
Most central banks around the world have increased their transparency in the recent past. The greater openness of central bankers manifests itself in the publication of the central banks' own macroeconomic forecasts or the disclosure of minutes and voting records of central bank committees. The intention of this policy is to build credibility and achieve better economic outcomes. The question is whether higher transparency comes at some cost, i.e. higher unemployment or higher unemployment variability. Firstly, the article shows in a theoretical model that opaqueness regarding the central bank's preferences does not necessarily lead to lower unemployment. Secondly, the paper analyses the main theoretical results of other authors, namely that transparency leads to higher wages, higher unemployment, and higher unemployment volatility. The results of the estimations show that there is no evidence that central bank transparency leads to higher wages. We can also reject the hypothesis that transparency induces higher unemployment. In fact, the analyses show that central bank transparency can reduce the detrimental effect that central bank independence has on employment. Furthermore, the estimations confirm that central bank transparency does not lead to higher unemployment volatility but can reduce it in most cases.
\end{abstract}

JEL: E24, E42, E58

Keywords: Central Bank Transparency, Unemployment, Determinants of Unemployment Rates

Address for correspondence:

Christoph Weber

Institute of Economics

University of Erlangen-Nuremberg

Kochstr. 4 (17)

D-91054 Erlangen

Phone: (+49) 91318522733

E-mail: Christoph.Weber@fau.de

\footnotetext{
* The author wishes to thank Jürgen Kähler, Hermann Gartner, Katrin Wölfel, and participants of the $22^{\text {nd }}$ BGPE Research Workshop, DIW Macroeconometric Workshop (2016), the $25^{\text {th }}$ International Rome Conference on Money, Banking, and Finance, and research seminars at FAU Erlangen-Nuremberg for very useful comments and suggestions. Financial support by the BGPE for acquiring a dataset is greatly appreciated.
} 


\section{Introduction}

The role of central bank transparency has largely increased in the last decades. Thereby, central bank transparency includes - inter alia - the publishing of economic models, data, and forecasts, the quantification of central bank targets, the publishing of the monetary policy strategy and the explanation of monetary policy decisions.

The main reasons for the increase in central bank frankness are that theoretical and empirical analyses showed that central bank transparency might be welfare enhancing and that central bank transparency is the flipside of central bank independence - at least in democratic systems. Central bank transparency is also an integral part of Inflation Targeting.

First and foremost, some studies show that central bank transparency might be helpful bringing down inflation. Theoretical analyses like the one of Eijffinger et al. (2000) and Geraats (2005) link higher central bank transparency to more stable prices. The empirical study by Fatás et al. (2007) finds that political transparency captured by a dummy variable for having an explicit goal leads to lower average inflation. This leads to the question of whether central bank transparency is a "free lunch", meaning that it comes at no cost, or whether lower central bank opaqueness is related to stricter monetary policy which results in higher unemployment rates. The relation between central bank transparency and unemployment has largely been ignored in the literature. Two theoretical studies stand out: Sørensen (1991) argues that uncertainty about the preferences of the central bank would lead unions to have lower wage claims which results in lower unemployment rates. Subsequently, Grüner (2002) also concludes that wages decline if uncertainty about the monetary policy reaction function rises. At the same time, there is a complete lack of studies analysing the connection between transparency and unemployment that takes into account all determinants of unemployment. This study fills this gap by conducting a panel data estimation of the impact of transparency on wages and unemployment while controlling for other unemployment causes. Thereby, the study employs different data sets that capture labour market institutions along with standard macroeconomic variables.

Initially, the theoretical considerations show that the presumption that opaqueness regarding the central bank's preferences leads to lower wages and lower unemployment is not necessarily true. The empirical estimations reveal that central bank transparency does not lead to higher wages and higher unemployment. Finally, the paper analyses the effect of central bank transparency on unemployment variability. Here the article rejects the presumption that central bank transparency induces higher unemployment fluctuations. Thus, the main result in contrast to the majority of the theoretical literature is that the pessimistic view on central bank transparency might be unfounded as there is no evidence that transparency leads to higher unemployment (volatility).

The paper is structured as follows: section 2 reviews the theoretical literature on the impact of central bank transparency and central bank independence on unemployment and unemployment variability. Section 3 summarises previous empirical studies on determinants of unemployment. Section 4 describes the data set and the estimation approach. Section 5 shows the estimation results. Section 6 concludes. 


\section{Theoretical Background}

\subsection{Central Bank Transparency and Unemployment}

\subsubsection{A Simple Game Theoretic Model}

The theoretical model by Sørensen (1991) was the first to analyse the relation between political uncertainty and macroeconomic outcomes. The main conclusion of this paper is that uncertainty regarding the central bank's reaction function can increase social welfare. The following theoretical consideration is based on Sørensen's model but it is extended in several ways. In the model, there are two actors: the labour union and the central bank. The labour union's utility function is

$$
V=-\left(w-\pi-\omega^{*}\right)^{2}
$$

The loss of the central bank depends both on deviations from the inflation target and the unemployment target $u^{*}$. For the sake of simplicity, it is assumed that the inflation target is zero.

$$
L=-(1-\alpha) \pi^{2}-(1+\alpha)\left(u-u^{*}\right)^{2}
$$

The parameter $\alpha \in[-1 ; 1]$ tells us how much emphasis the central bank puts on stabilising unemployment rates. The larger $\alpha$ is, the more the central bank cares about deviations in unemployment rates. Thus, maximum central bank conservativeness would mean that $\alpha=-1$ as in this case the central bank would not care at all about reducing unemployment. 1

In this model, $w$ is the log nominal wage, $\pi$ is the $\log$ price level ${ }^{2}$, and $\omega^{*}$ is the real wage goal of the trade union. The unemployment rate $u$ is given by

$$
u=a+w-\pi+\epsilon
$$

Thereby, the unemployment rate $u$ is determined by a constant, the real wage $(w-\pi)$ plus a shock term $\epsilon$. If the union reaches its wage goal, unemployment will be larger than $u^{*}$, i.e. $a+$

\footnotetext{
${ }^{1}$ This refers to the famous time-inconsistency problem mentioned by Kydland and Prescott (1977). Rogoff (1985) argued that monetary policy should be given in the hands of a conservative central banker. Conservativeness means that the central bank puts a stronger emphasis on price stability than government and society and that it does not care so much about output stabilisation.

${ }^{2}$ If we assume that price level of the previous period is 1 , then $\pi$ is not only the log price level of the current period, but at the same also approximately the inflation rate.
} 
$\omega^{*}>u^{*}$. Furthermore, central bank knows the actual value of the shock whereas the trade union only knows the expected value of the shock, $E(\epsilon)=0$, and its variance $\sigma_{\epsilon}^{2}$. $^{3}$

The model assumes that the trade union can set the nominal wage rate and the central bank can set inflation (either directly or by manipulating the money supply). The idea of the model is that the labour union moves first before the central bank takes its decision.

The transparency effect comes into play when thinking about the central bank objective function (2). Of course, the central bank knows its preferences and thus also the value of the parameter $\alpha$. For instance, the preferences of the central bank might change if a new governor takes office or if the government changes from right-wing to left-wing or vice versa. Still the model assumes that the expected value of parameter $\alpha$ is constant where the variance of the parameter is $\sigma_{\alpha}^{2}$. Although it might be reasonable to think of a relation between the shock to the unemployment rate $\epsilon$ and the weight on the unemployment goal $\alpha$, the model assumes that those two parameter are uncorrelated.

Before we derive the first order conditions, we first replace the unemployment rate $u$ in equation (2) by the definition of the unemployment rate stated in equation (3). That leads us to the following objective function of the central bank:

$$
L=-(1-\alpha) \pi^{2}-(1+\alpha)\left(a+w-\pi+\epsilon-u^{*}\right)^{2}
$$

The first derivative of this expression with respect to $\pi$ (the variable the central bank can control) is therefore:

$$
\frac{\partial L}{\partial \pi}=-2(1-\alpha) \pi+2(1+\alpha)\left(\alpha+w-\pi+\epsilon-u^{*}\right)
$$

After some further steps we end up with the condition for minimising the central bank's loss:

$$
\pi^{*}=\frac{1}{2}(1+\alpha)\left(a+w+\epsilon-u^{*}\right)
$$

The higher $\alpha$ is, the higher the inflation rate will be. As mentioned before, $\alpha$ is basically a measure for central bank conservativeness (in terms of targeting price stability). The lower $\alpha$ is, the more conservative the central bank is. Higher conservativeness would result in lower inflation rates.

Following the Barro-Gordon-model, there are three different scenarios depending on how trade unions build their inflation expectations and how the central bank sets the inflation rate. The trade union could either trust the central bank's announcement regarding future inflation or it could take the optimal inflation rate from the perspective of the central bank into account (i.e. rational expectations). The central bank can either commit to its pre-announced inflation target

\footnotetext{
${ }^{3}$ The expected value of $\epsilon^{2}$ can be derived from $E(\epsilon \cdot \epsilon)=E(\epsilon) \cdot E(\epsilon)+\operatorname{Cov}(\epsilon, \epsilon)=E(\epsilon) \cdot E(\epsilon)+\operatorname{Var}(\epsilon)=$ $\sigma_{\epsilon}^{2}$. Assuming that the shock term is correlated with itself, the expected value of the squared shock term is equal to the variance of the shock term $\left(\sigma_{\epsilon}^{2}\right)$.
} 
or it could fool the public and set the inflation rate equal to its optimal inflation rate (according to (6)).

Let us start with the first scenario in which inflation expectations are zero and the central bank commits to its inflation target.

$$
\pi^{e}=\pi=0
$$

The optimal decision of the trade union depends on its value function:

$$
V=-\left(w-\pi^{e}-\omega^{*}\right)^{2}
$$

In this case, $\pi^{e}$ would drop out as the union expects zero inflation reducing the value function to:

$$
V_{\pi^{e}=0}=-\left(w-\omega^{*}\right)^{2}
$$

Then the optimal decision of the trade union can be computed by taking the first derivate of the value function with respect to the wage:

$$
\frac{\partial V_{\pi^{e}=0}}{\partial w}=-2 w+2 \omega^{*}
$$

Setting this expression equal to zero gives the maximum and, thus, the optimal wage rate of the trade union when assuming zero inflation:

$$
W^{*}{ }^{e}=0=\omega^{*}
$$

Not surprisingly, the optimal decision of the trade union would just be to set the nominal wage equal to its real wage target $\omega^{*}$. Assuming that the central bank commits to its preannounced target, the actual inflation rate would be zero. In this situation, nominal and real wage would be identical. Then the unemployment rate would be:

$$
u_{\pi}^{e=\pi=0}=a+\omega^{*}+\epsilon
$$

Given the fact that $a+\omega^{*}$ is larger than $u^{*}$ (by assumption), the central bank would not meet its unemployment target under this scenario in the absence of a large positive $\operatorname{shock}^{4}$ (i.e. if $\epsilon \geq$ $\left.u^{*}-a-\omega^{*}\right)$.

Next we analyse the case of surprise inflation where inflation expectations are zero but the central bank chooses an inflation rate that is equal to its optimal inflation rate under these

\footnotetext{
${ }^{4}$ Here a positive shock is defined as a situation in which $\epsilon<0$ as this would be a shock that reduces unemployment and inflation.
} 
circumstances. In that scenario, the wage rate would again be $\omega^{*}$. However, in this case the central bank would include this wage in its reaction function:

$$
\pi^{*} w^{*}=\omega^{*}=\frac{1}{2}(1+\alpha)\left(a+\omega^{*}+\epsilon-u^{*}\right)
$$

If the central bank is not maximally conservative $(\alpha>-1)$, the inflation rate will be positive in the absence of a positive shock. Then the unemployment rate would be:

$$
u_{\pi^{e}=0}=a+\omega^{*}-\frac{1}{2}(1+\alpha)\left(a+\omega^{*}+\epsilon-u^{*}\right)+\epsilon
$$

After some algebra, we end up with the following solution for the unemployment rate:

$$
u_{\pi^{e}=0}=\frac{1}{2}(1-\alpha)\left[a+\omega^{*}+\epsilon\right]+\frac{1}{2}(1+\alpha) u^{*}
$$

It is helpful to rewrite this equation:

$$
u_{\pi^{e}=0}=\frac{1}{2}\left(a+\omega^{*}+u^{*}\right)-\frac{1}{2} \alpha\left(a+\omega^{*}-u^{*}\right)+\frac{1}{2}(1-\alpha) \epsilon
$$

First of all, we see that if the central bank is maximally conservative $(\alpha=-1)$, the inflation would be zero according to (13) and then the unemployment rate would be the same as in the case of rule-binding monetary policy (i.e. as in equation (12)). Next we see that higher levels of $\alpha$ lead to lower unemployment rates. As by definition $a+\omega^{*}-u^{*}>0$, increases in $\alpha$ would decrease the second term (including the negative sign) of equation (16).

The third possibility is, of course, the rational expectations solution where the trade union takes the optimal decision of the central bank into account. Here we have to assume that the trade union knows what the central bank's optimal decision looks like. We distinguish the two cases where the trade union knows or does not know the value of $\alpha$. Given that the trade union has to move first, it would simply replace the expected inflation rate in its value function by the optimal inflation decision from the perspective of the central bank:

$$
V=-\left(w-\pi^{e}-\omega^{*}\right)^{2}=-\left(w-\frac{1}{2}(1+\alpha)\left(a+w+\epsilon-u^{*}\right)-\omega^{*}\right)^{2}
$$

Then the first order condition with respect to the wage rate is derived:

$$
\frac{\partial V}{\partial w}=-2\left(w-\frac{1}{2}(1+\alpha)\left(a+w+\epsilon-u^{*}\right)-\omega^{*}\right)\left(1-\frac{1-\alpha}{2}\right)
$$

By setting this expression equal to zero, we can find the maximum of the value function and, thus, the optimal decision of the trade union:

$$
W_{P I}^{*}=\frac{\left(1-\alpha^{2}\right)\left(a+\epsilon-u^{*}\right)+2 \omega^{*}-2 \alpha \omega^{*}}{(1-\alpha)^{2}}
$$


Now we can analyse how the wage decision of the trade union depends on the parameter $\alpha$ by differentiating the optimal wage decision of the trade union with respect to $\alpha$ :

$$
\frac{\partial w_{P I}^{*}}{\partial \alpha}=-\frac{2\left[u^{*}-\left(a+\omega^{*}\right)-\epsilon\right]}{(\alpha-1)^{2}}
$$

To recap briefly, $a+\omega^{*}$ is assumed to be larger than $u^{*}$. Therefore, the term $u^{*}-\left(a+\omega^{*}\right)$ is negative. Furthermore, $\alpha$ has values from -1 to 1 which means that the denominator can have values from 4 to 0 . Thus, the whole expression in equation (20) is positive. That means that increases in $\alpha$ translate into higher wages. Knowing the optimal decision of the trade union, we can also determine the inflation rate and the unemployment rate in this scenario. When determining the optimal inflation rate, we can replace $w$ in equation (6) with the result from equation (19):

$$
\begin{gathered}
\pi_{P I}^{*}=\frac{1}{2}(1+\alpha)\left(a+w+\epsilon-u^{*}\right)= \\
=\frac{1}{2}(1+\alpha)\left(a+\frac{\left(1-\alpha^{2}\right)\left(a+\epsilon-u^{*}\right)+2 \omega^{*}-2 \alpha \omega^{*}}{(1-\alpha)^{2}}+\epsilon-u^{*}\right)=\frac{(1+\alpha)\left(a+\epsilon+\omega^{*}-u^{*}\right)}{1-\alpha}
\end{gathered}
$$

Knowing the wage rate and the inflation rate, we can then determine the unemployment rate based on equation (3):

$$
\begin{gathered}
u_{P I}=a+w-\pi+\epsilon= \\
=a+\frac{\left(1-\alpha^{2}\right)\left(a+\epsilon-u^{*}\right)+2 \omega^{*}-2 \alpha \omega^{*}}{(1-\alpha)^{2}}+\frac{(1+\alpha)\left(a+\epsilon+\omega^{*}-u^{*}\right)}{1-\alpha}+\epsilon=a+\omega^{*}+\epsilon
\end{gathered}
$$

As it turns out, the unemployment rate in this scenario will always be $\left(a+\omega^{*}+\epsilon\right)$ no matter what the value of the preference parameter $\alpha$ is. Higher values of $\alpha$ would lead the union to demand higher wages and, in turn, force the central bank to inflate away the wage increases. The unemployment rate would be the same as in equation (12) when inflation expectations are zero and the central bank commits to its preannounced target. The only difference would be that nominal wages and inflation would be different at different levels of $\alpha$ where the real wage would always be equal to $\omega^{*}$.

This would be the result for the situation where the trade union knows the exact value of the preference parameter of the central bank. However, the model by Sørensen (1991) assumes that the trade union does not know the actual preferences of the central bank. The labour union expects that $E(\alpha)=0$ and that $E\left(\alpha^{2}\right)=\sigma_{\alpha}^{2}$. Thus, the union would take the expected reaction of the central bank into consideration while replacing $\alpha$ and $\alpha^{2}$ with their expected values. Consequently, the optimal decision of the trade union - equation (20) - would slightly change to:

$$
w_{E(\alpha)=0 ; E\left(\alpha^{2}\right)=\sigma_{\alpha}^{2}}^{*}=\frac{\left[\left(1-\sigma_{\alpha}^{2}\right)\left(a+\epsilon-u^{*}\right)+2 \omega^{*}\right]}{1+\sigma_{\alpha}^{2}}
$$


In this expression, we can also delete $\epsilon$ as the trade union expects $\epsilon$ to be zero. The idea of Sørensen (1991) is to interpret $\sigma_{\alpha}^{2}$ as a measure for central bank transparency. Higher values of $\sigma_{\alpha}^{2}$ symbolise lower central bank transparency. Thus, it is useful to estimate the effect of an increase in political uncertainty to the wage rate by taking the derivate of (23) with respect to $\sigma_{\alpha}^{2}$ :

$$
\frac{\partial w_{E(\alpha)=0 ; E\left(\alpha^{2}\right)=\sigma_{\alpha}^{2}}^{*}}{\partial \sigma_{\alpha}^{2}}=\frac{-2\left(a+\omega^{*}-u^{*}\right)}{\left(1+\sigma_{\alpha}^{2}\right)^{2}}
$$

The formula says that an increase in political uncertainty (i.e. a decrease in transparency) leads to a decrease in wages. This is the main argument against transparency. The result comes from the assumption that the trade union dislikes deviations from their real wage target and that it dislikes uncertainty about the real wage (Sørensen, 1991). This is the result of the assumption that the trade union is risk averse regarding the real wage. As the trade union sets the nominal wage, there is only uncertainty regarding the price level. ${ }^{5}$

The inflation rate is given by expression (6). Here we can insert the trade union's decision about the nominal wage (23). This leads to

$$
\pi_{E(\alpha)=0 ; E\left(\alpha^{2}\right)=\sigma_{\alpha}^{2}}^{*}=\frac{1}{2}(1+\alpha)\left(a+w+\epsilon-u^{*}\right)=(1+\alpha) \frac{a+\omega^{*}-u^{*}+\epsilon}{1+\sigma_{\alpha}^{2}}
$$

Then the unemployment rate will be

$$
\begin{aligned}
u_{E(\alpha)=0 ; E\left(\alpha^{2}\right)=\sigma_{\alpha}^{2}} & =a+\frac{\left[\left(1-\sigma_{\alpha}^{2}\right)\left(a+\epsilon-u^{*}\right)+2 \omega^{*}\right]}{1+\sigma_{\alpha}^{2}}-(1+\alpha) \frac{a+\omega^{*}-u^{*}+\epsilon}{1+\sigma_{\alpha}^{2}}+\epsilon= \\
& =\frac{(1-\alpha)\left(a+\omega^{*}+\varepsilon\right)+\left(\alpha+\sigma_{\alpha}^{2}\right) u^{*}}{1+\sigma_{\alpha}^{2}}
\end{aligned}
$$

Now here comes Sørensen's story. What happens to inflation and wages when uncertainty regarding the central bank's preferences $\left(\sigma_{\alpha}^{2}\right)$ increases. We can assess this by taking the first derivatives of both inflation and unemployment with respect to $\sigma_{\alpha}^{2}$ to assess the impact of a decrease in transparency:

$$
\begin{aligned}
& \frac{\partial \pi_{E(\alpha)=0 ; E\left(\alpha^{2}\right)=\sigma_{\alpha}^{2}}^{*}}{\partial \sigma_{\alpha}^{2}}=-\frac{(1+\alpha)\left(a+\omega^{*}-u^{*}+\epsilon\right)}{\left(1+\sigma_{\alpha}^{2}\right)^{2}}<0 \\
& \frac{\partial u_{E(\alpha)=0 ; E\left(\alpha^{2}\right)=\sigma_{\alpha}^{2}}}{\partial \sigma_{\alpha}^{2}}=-\frac{(\alpha-1)\left(u^{*}-\left(a+\omega^{*}\right)-\epsilon\right)}{\left(1+\sigma_{\alpha}^{2}\right)^{2}}<0
\end{aligned}
$$

\footnotetext{
${ }^{5}$ It can easily be seen from the value function that the trade union is risk averse as the expected utility of a certain real wage $E(V(x))$ is lower than the utility of an expected real wage $V(E(x))$. To take a very simple numerical example, let us assume that with equal probabilities of 0.5 the deviation of the real wage from the target is -2.5 and 2.5 , respectively. Whilst the utility of the expected real wage deviation is 0 , the expected utility is $E(V)=0.5\left[-(-2.5)^{2}\right]+0.5\left[-(2.5)^{2}\right]=-6.25$. This confirms that the trade union is risk averse.
} 
Given that $a+\omega^{*}$ is larger than $u^{*},\left(a+\omega^{*}-u^{*}\right)$ will be positive and $\left(u^{*}-\left(a+\omega^{*}\right)\right)$ will be negative. Furthermore, we know that $\alpha$ can have values from -1 to 1 . Thus, $(1+\alpha)$ can have values from 0 to 2 and $(\alpha-1)$ can have values from -2 to 0 . Eventually, both expressions turn out to be negative. This is the main conclusion by Sørensen: uncertainty regarding the preferences leads both to lower inflation and lower unemployment rates.

The model also tells us that the central bank has two ways to influence macroeconomic outcomes. Firstly, it can manipulate the inflation rate. Secondly, it can influence the trade union's decision by changing the political transparency.

However, it is not necessarily the better option for the central bank to hide its preferences. From an analytical point of view, we can compare two scenarios: one in which the trade union knows the preference parameter $\alpha$ and one in which it does not know $\alpha$ but assumes that $E(\alpha)=0$ and that $E\left(\alpha^{2}\right)=\sigma_{\alpha}^{2}$. The unemployment rate in the scenario with perfect information was given in equation (22) while the unemployment rate in case of imperfect information was shown in equation (26). Now we can compare both results to analyse when unemployment will be higher under imperfect information:

$$
\begin{gathered}
u_{P I}<u_{E(\alpha)=0 ; E\left(\alpha^{2}\right)=\sigma_{\alpha}^{2}} \\
a+\omega^{*}+\epsilon<\frac{(1-\alpha)\left(a+\omega^{*}+\varepsilon\right)+\left(\alpha+\sigma_{\alpha}^{2}\right) u^{*}}{1+\sigma_{\alpha}^{2}} \\
\sigma_{\alpha}^{2}<-\alpha
\end{gathered}
$$

After some algebra, it turns out that the unemployment rate in the case of imperfect information is higher compared to the case of perfect information as long as $-\alpha>\sigma_{\alpha}^{2}$. This would mainly be true for situations with very conservative central banks (low values of $\alpha$ ).

To relax the assumption that $E(\alpha)=0$ we consider a scenario where the union assumes $E(\alpha)=\beta$. This value could be equivalent to the actual parameter but it could also be different as we assume that the trade union does not have perfect information regarding the central bank's reaction function. The optimal decision of the labour union in the case of imperfect information (II) would be:

$$
W^{*}{ }_{I I}=\frac{\left(1-\beta^{2}\right)\left(a+\epsilon-u^{*}\right)+2 \omega^{*}-2 \beta \omega^{*}}{(1-\beta)^{2}}
$$

Again, the central bank would derive its decision based on the wage rate requested by the trade union:

$$
\begin{gathered}
\pi^{*}{ }_{I I}=\frac{1}{2}(1+\alpha)\left(a+w+\epsilon-u^{*}\right)= \\
=\frac{1}{2}(1+\alpha)\left(a+\frac{\left(1-\beta^{2}\right)\left(a+\epsilon-u^{*}\right)+2 \omega^{*}-2 \beta \omega^{*}}{(1-\beta)^{2}}+\epsilon-u^{*}\right)=\frac{(1+\alpha)\left(a+\omega^{*}+\epsilon-u^{*}\right)}{1-\beta}
\end{gathered}
$$


The optimal decision of the central bank depends both on the actual preference parameter $\alpha$ and the assumed preference parameter by the central bank $(\beta)$. Of course, the result would be the same as in the case of perfect information if the assumed preference parameter matches the actual one. Finally, we can once again consider the unemployment rate:

$$
\begin{gathered}
u_{I I}=a+w-\pi+\epsilon= \\
=a+\frac{\left(1-\beta^{2}\right)\left(a+\epsilon-u^{*}\right)+2 \omega^{*}-2 \beta \omega^{*}}{(1-\beta)^{2}}+\frac{(1+\alpha)\left(a+\omega^{*}+\epsilon-u^{*}\right)}{1-\beta}+\epsilon= \\
=a+\frac{\left(\alpha \beta-\alpha+\beta-\beta^{2}\right)\left(a+\epsilon-u^{*}\right)+(\alpha \beta-\alpha-\beta+1) \omega^{*}}{(1-\beta)^{2}}+\epsilon
\end{gathered}
$$

Once again, transparency is beneficial if the unemployment rate in the scenario of perfect information is lower compared to a situation with imperfect information. This would be the case if the following inequality is satisfied:

$$
\begin{gathered}
u_{P I}<u_{I I} \\
a+\omega^{*}+\epsilon<a+\frac{\left(\alpha \beta-\alpha+\beta-\beta^{2}\right)\left(a+\epsilon-u^{*}\right)+(\alpha \beta-\alpha-\beta+1) \omega^{*}}{(1-\beta)^{2}}+\epsilon
\end{gathered}
$$

$$
\beta>\alpha
$$

After some simplifications of inequality (33b), it turns out that the condition is satisfied if $\beta>$ $\alpha$. That means that the unemployment rate in the case of imperfect information will be higher than in the case of perfect information if the trade union expects the central bank to be less conservative than it actually is. In reality, this should be more likely if the central bank is very conservative and puts a strong weight on price stability where trade unions think that the central bank would fight high unemployment rates.

Overall, we have seen that in contrast to Sørensen's (1991) prediction it is not always beneficial for the central bank to hide its actual preferences. In fact, under certain circumstances it is better to tell the public the truth about actual central bank intentions.

\subsubsection{Further Arguments against Central Bank Transparency}

There are some other models that also analyse the role of opaqueness from a theoretical point of view. A paper much in the fashion of Sørensen (1991) is Grüner (2002). Grüner also concludes that uncertainty with respect to central bank preferences reduces wages and unemployment.

Spyromitros and Zimmer (2009) follow the arguments by Sørensen and Grüner. It is assumed that labour unions do not have perfect information about the central bank's reaction function. The game-theoretic approach is Bertrand competition. The main results of this paper are that higher monetary policy uncertainty reduces unemployment rates. Furthermore, they find that a monetary policy rule with a larger weight on inflation increases unemployment if the central 
bank is expected to accommodate wage increases and the uncertainty regarding monetary policy is high. Again, monetary policy uncertainty is just related to the variance of the preference parameter. Transparency is then given by the fluctuation of the preference parameter. Thus, the main conclusion of this work is that a conservative central bank will probably lead to higher unemployment rates.

Grüner, Hayo, and Hefeker (2009) extend this by also analysing the role of monetary policy uncertainty. In a theoretical model, they show that uncertainty about the monetary policy stance reduces wage claims of trade unions. The result is lower unemployment rates. The model itself is also in the fashion of Sørensen (1991). The main differences of the model are that it establishes a labour demand equation and that it uses a multitude of trade unions. Transparency is again defined as uncertainty regarding the central bank's preferences. They also test this model empirically by using a VECM approach. Monetary policy uncertainty is proxied by the change of the conditional variance of the expected short-term interest rate. The study looks at five countries and finds that monetary policy uncertainty leads to lower nominal wage growth in France, Germany, and Japan while it has no impact on the wage growth of the UK and the US.

The paper by Hefeker and Neugart (2014) extends the previous models by introducing labour market institutions. The model itself is based on an earlier work by Calmfors (2001) in which the government is the Stackelberg leader. In this model, there are both a government and a central bank. The previous models did not distinguish between those two actors. Both players have a loss function where the loss positively depends on inflation and unemployment rates. The government faces further losses if it conducts labour market reforms given that they might be unpopular and might decrease their re-election chances in the short run. The main message of this model is that uncertainty regarding the central bank preferences leads the government and the union to be less aggressive assuming that both are averse to economic uncertainty. If the government knows that the central bank puts a high emphasis on reducing unemployment, then it is less inclined to conduct labour market reforms. Uncertainty regarding the central bank's reaction function also has the same effect namely to lead the government to reduce labour market regulation.

The problem of this model is clearly that it assumes that the government does not know what the central bank will do. This assumption is not realistic as governments do have a strong impact on the central bank's decisions. Governments can change central bank laws in order to force them to be more accommodative. They can also reduce central bank independence with the aim of increasing their influence on actual monetary policy decisions. Simply the awareness that political majorities can change the status of the central bank can lead to anticipatory obedience by the central bank. This explains why central banks that are relatively independent of direct government interventions still behave in a manner that the ruling political majority prefers. ${ }^{6}$ For instance, there is evidence that the behaviour of the Federal Reserve System is different between times of Republican or Democratic presidencies (Jones and Snyder, 2014). Froyen, Havrilesky,

\footnotetext{
${ }^{6}$ Of course, this does not imply that the government knows the actual preferences of the central bank. For instance, the central bank could report wrong information to the government so as to pretend to have preferences more in line with those of the government.
} 
and Waud (1997) emphasise the general influence of political pressure of monetary policy decisions in the US.

All the studies mentioned up to this point argue that central bank transparency is not desirable as it leads to higher unemployment rates. The study by Ciccarone, Marchetti, and di Bartolomeo (2007) delivers a result that is not clear cut. The model uses an AS-AD model with a government, a central bank, and a trade union as actors. The study concludes that central bank transparency leads to higher unemployment if the central bank puts a high weight on unemployment stabilisation. On the other hand, central bank transparency would reduce unemployment if the government cares greatly about inflation and if the government is willing to conduct expansionary fiscal policy to fight unemployment. However, central bank transparency would lead to higher unemployment if the government cares more about unemployment and if it is not capable of conducting fiscal policy due to funding shortfalls.

\subsubsection{Further Arguments in Favour of Central Bank Transparency}

Sánchez (2011) draws a much more positive picture of central bank transparency as they argue that it can decrease rather than increase unemployment. The model in Sánchez (2011) is a game between a monopoly union and a central bank where the central bank is the Stackelberg leader. Again both agents want to minimise their loss. In this approach, the union's loss also depends on the overall unemployment rate which is a reasonable assumption if there is only one union. Sánchez (2011) shows that lower central bank transparency with respect to the central bank's reaction function reduces nominal wages if the central bank is perceived as relatively liberal. If the reaction function of the central bank is uncertain, an increase in central bank transparency reduces expected inflation, real wages, and unemployment. The reason behind that is that trade unions are less aggressive when they are not fully aware of the central bank's preferences. If the preferences are well known, then a decrease in transparency increases inflation uncertainty. However, this would not have an effect on real wages and unemployment assuming that there is only one trade union. The effect on inflation uncertainty might still be relevant as we will see later on. Analysing a situation with atomistic unions (i.e. perfect competition), central bank transparency has a dampening effect on inflation volatility both when the preferences are well known and when they are relatively uncertain.

Laskar (2010) argues that most models use reduced form models. In such a scenario, it is always better if the private sector does not know the central bank's forecast of the shock in the Phillips curve equation. The model of Laskar (2010) includes a loss function for trade unions where the trade union sets the wage and the central bank sets the inflation rate. In this model, the shock is lower if the central bank is transparent about the shock. The result is that transparency about the shock is better if the relative weight that unions put on overall employment is higher than the relative weight that central bank puts on employment and vice versa. If this is the case, then the trade unions' behaviour leads to better employment stabilisation compared to a situation where the central bank does not publish its forecasts error and can use surprise inflation to stimulate employment. If the central bank is fully transparent, it cannot create surprise inflation. However, trade unions can still set nominal wages so that the economy can cope with shocks. 


\subsection{Central Bank Independence and Unemployment}

The models presented so far mainly focus on the impact of central bank transparency for unemployment. However, it is also useful to consider the impact of central bank autonomy on unemployment.

Bleaney (1996) develops a model to analyse the effect of central bank independence. The proposition of this model is that central bank independence does not have an effect on unemployment rates but only on inflation rates. On the other hand, the model predicts that the wage bargaining structure influences the equilibrium unemployment rate. The wage-bargaining structure is proxied by the number of trade unions. The relation between the number of unions (centralisation of wage bargaining) and unemployment is hump-shaped just like in the model of Calmfors and Driffill (1988).

Cukierman and Lippi (1999) take on this idea and develop it further. The theoretical model predicts that higher central bank independence leads to higher unemployment rates if either the trade unions are inflation averse or if there are several unions and workers of these unions are at least partly interchangeable. Given atomistic unions, this effect almost disappears. According to the model, an ultra-liberal central bank (i.e. a central bank does not target inflation but only unemployment) leads to the optimal outcome if it is confronted with a monopoly trade union. Cukierman and Lippi argue that it is still better to have a central bank that is more liberal than what the social optimum is although the effect vanishes the more unions there are.

Guzzo and Velasco (1999) employ a general equilibrium model including unions that are inflation averse. The model hypothesises that an ultra-liberal central bank is optimal if there is a fixed number of unions. According to the model, central bank conservativeness leads to higher unemployment because the trade unions would demand higher wages knowing that the effect of higher wages on inflation is lower if the central bank is more conservative. ${ }^{7}$ Lippi (2002) criticises Guzzo and Velasco (1999) as they assume that trade unions take the real wages of other unions as given. Under this assumption, a maximally liberal central bank is optimal. If the Guzzo and Velasco (1999) is replicated with the assumption that each trade union takes the nominal wages of other trade unions as given, then a populist central bank is only optimal if there is only one trade union. If, however, there is more than one trade union, then the optimal degree of central bank conservativeness depends on how inflation averse workers are.

Furthermore, several articles emphasise the interplay between central bank independence and centralisation of wage bargaining. It all started with a debate over organised market economies, i.e. economies in which both employers and employees are organised in associations or unions that negotiate wages and other work related issues. Iversen's (1998b) argument is that there are two combinations that are stable: either wage bargaining is centralised and monetary policy is accommodating or wage bargaining is decentralised and monetary policy is nonaccommodating. Non-accommodating monetary policy means that the central bank reacts to price increases with strict contractionary monetary policy to squeeze out inflation. Here accommodation means that the central bank accepts price increases if it helps to keep

\footnotetext{
${ }^{7}$ In this paper, central bank independence and central bank conservativeness are assumed to be substitutes. Broadly speaking, central bank independence means that the central bank can take its decision without direct influence from the government. Conservativeness means that the central bank puts a stronger emphasis on price stability than government and society. Following Berlemann and Hielscher (2013), CBI is necessary but not sufficient to solve the time-inconsistency problem.
} 
employment at the full employment level. The first system, namely centralised accommodation, works because in this system macroeconomic policy and the actions by employers' associations and trade unions are coordinated. In a decentralised system with a non-accommodating central bank, the unions anticipate the behaviour of the central bank. Having a system with decentralised wage bargaining and an accommodating central bank is problematic. If the negotiating partners of wages know that the central bank will eventually conduct expansionary monetary policy in the case of real wage increases in order to prevent unemployment increases, workers and employers might root for higher wages as they would at least benefit from lower import prices resulting from the looser monetary policy. However, the central bank must be credible in threatening the other agents about wage increases in a system of decentralised nonaccommodation. To signal the public its willingness to be strict in times of wage increases, the government could grant the central bank independence as autonomous central banks are very often perceived as more conservative.

Summarising Iversen (1998b), the effect of central bank independence on unemployment depends on whether wage bargaining is centralised or decentralised at the sector or industry level. While the arguments in Iversen (1998b) are purely verbal, Iversen (1998a) presents a formal game-theoretical model to support his argument. As he elaborates, the model by Calmfors and Driffill (1988) does not include central banks and assumes that prices only depend on wages. In Barro's and Gordon's (1983) model, the central bank sets the price level while wages have no effect on inflation. A third strand in the literature is the so called "distributive politics approach" which combines wage bargaining and monetary policy. The model by Iversen predicts that non-accommodating monetary policy leads to higher unemployment in highly centralised systems, to better outcomes in intermediately centralised systems, and to no effects in decentralised systems.

Also Hall and Franzese (1998) argue that central bank independence might increase unemployment. This would especially be the case if coordination of wage bargaining is low. The idea is that unions demand higher nominal wages if they are concerned about central banks exploiting the Philipps curve trade-off leading to higher inflation and, thus, to lower real wages. Central bank independence can work as a signal that the central bank is not likely to use surprise inflation. However, if this signal is not perceived as credible or if employers and unions do not coordinate their behaviour, then tight monetary policy leads to higher unemployment.

The model of Skott (1997) introduces the government as another actor in a set-up with Stackelberg competition. The trade union is assumed to be the Stackelberg leader. In this setting, a maximally liberal central bank is optimal when there is only one trade union. Also in the case of decentralised wage bargaining, it is optimal if the central bank does not care about inflation. However, the output target should be different from the output target of the government. In the case of hysteresis (where the employment target of the trade union depends on the amount of employment in the last period), it is always optimal if the central bank does not care about inflation as in this set up inflation in the long-run will be zero. This is the case because the unemployment target of the trade unions will converge to the unemployment target of the central bank.

Another addition is made by Lawler (2000) who includes stochastic productivity shocks in the model. The model includes a single trade union with employment target below equilibrium employment. Furthermore, there are firms that produce a homogenous good using labour. In 
the model, it is optimal to select a maximally liberal central banker in the case of no stochastic shocks. In the case of stochastic shocks, it is optimal if the central bank puts a lower weight on inflation than society does but not a weight of zero.

In contrast to the previous studies, some other articles find central bank conservativeness to be negatively related to unemployment. Soskice and Iversen (2000) present a model with firms acting under monopolistic competition producing one good. In this model, output is higher in the case where the central bank is not completely liberal if there is a fixed number of unions. This is the case because the producers realise that inflation will be higher if they charge higher prices for their products. If inflation is higher, real money supply will be lower. In another variant of the model with several sectors, one trade union per sector, and no mobility of workers between the sectors, the result is the same. Bratsiotis and Martin (1999) also assume monopolistic competition among firms. Here the trade unions set wages and then the firms set employment and prices. Finally, the central bank decides about money supply. In this model, lower central bank conservativeness decreases wage elasticity of labour demand. It also reduces elasticity of goods demand. The result is higher unemployment. Another extension is made by Cukierman and Dalmazzo (2006) who include a government that can raise a social security tax and income tax and can pay unemployment benefits. Under these assumptions, higher central bank conservativeness leads to lower real wages and, thus, to lower unemployment in the case where fiscal policy is exogenous. In the case of endogenous fiscal policy, higher central bank conservativeness leads to higher taxes and unemployment benefits if the unemployment rate is below $50 \%$.

Cukierman (2008) and Coricelli, Cukierman, and Dalmazzo (2006) summarise that models assuming that unions dislike inflation and that central banks can directly control inflation come to the conclusion that central bank independence leads to higher real wage demands and, thus, higher unemployment. In these models, the supply side effect dominates. On the other hand, models assuming that central banks can manipulate the money supply, and thus aggregated demand, but who cannot directly influence inflation, conclude that central bank independence lowers unemployment. In these models, higher wage demands lead to lower money growth. Thus, trade unions will reduce their wage claims if the central bank is very conservative. Coricelli, Cukierman, and Dalmazzo (2006) combine both approaches. In the model, the relationship between central bank conservativeness and unemployment is non-linear. An increase in central bank conservativeness leads to higher unemployment if the central bank is relatively liberal but it decreases unemployment if the central bank is very conservative. If the trade unions have a stronger focus on employment goals in comparison to low inflation, then a maximally liberal central bank leads to lower unemployment. The rationale behind this is that, on the one hand, central bank conservativeness increases wage claims of trade unions as they know that the central bank will make sure that inflation will not be very high. On the other hand, central bank conservativeness reduces wage claims of trade unions as they expect the central bank to care less about employment. Thus, higher wage claims would translate into higher unemployment among their members. In the set-up of the model, the latter effect is dominated by the first effect.

According to Jordahl and Laséen (2005), central bank independence can have an indirect effect on unemployment as it increases the demand for labour market regulation. Thereby, the relation between independence and labour market regulation is hump-shaped with labour market 
regulation being the highest at a medium level of central bank conservativeness. And this increased labour market regulation (e.g. higher unemployment benefits) might then lead the central bank to focus even less on unemployment as they know that the costs of unemployment are lower if the social security system is more generous (Di Tella and MacCulloch, 2004).

\subsection{Central Bank Transparency and Unemployment Volatility}

Apart from the discussion on whether central bank transparency and independence affect unemployment, there is also a debate about whether both lead to higher unemployment volatility. In his seminal paper, Rogoff (1985) argues that assigning monetary policy to a conservative central banker can help to reduce the time-inconsistency problem, but it comes at the cost of higher employment fluctuation in the case of supply side shocks. This raises the question of whether higher unemployment volatility could also be a problem of central bank transparency. In order to answer this question, we will use the theoretical background from section 2.1.1.

When inflation expectations are zero and the central bank commits to its inflation target, the expected unemployment rate will be - based on equation (12):

$$
E\left(u_{\pi^{e}=\pi=0}\right)=a+\omega^{*}
$$

As mentioned in section 2.1.1, $E(\epsilon)=0$ and $E\left(\epsilon^{2}\right)=\sigma_{\epsilon}^{2}$. This leads to an expected variance of the unemployment rate of:

$$
\operatorname{Var}\left(u_{\pi^{e}=\pi=0}\right)=\left[u_{\pi^{e}=\pi=0}-E\left(u_{\pi^{e}=\pi=0}\right)\right]^{2}
$$

Thus, the variance of the unemployment rate is:

$$
\operatorname{Var}\left(u_{\pi^{e}=\pi=0}\right)=\left[\left(a+\omega^{*}+\epsilon\right)-\left(a+\omega^{*}\right)\right]^{2}=\sigma_{\epsilon}^{2}
$$

In this case, fluctuations of the unemployment rate only depend on the variance of the shock. If inflation expectations are zero but the central bank exploits the trade-off, the expected unemployment rate will be - following equation (16):

$$
E\left(u_{\pi^{e}=0}\right)=\frac{1}{2}\left(a+\omega^{*}+u^{*}\right)
$$

Thus, the variance of the unemployment rate in this scenario will be:

$$
\begin{gathered}
\operatorname{Var}\left(u_{\pi^{e}=0}\right)=\left[u_{\pi^{e}=0}-E\left(u_{\pi^{e}=0}\right)\right]^{2} \\
\operatorname{Var}\left(u_{\pi^{e}=0}\right)=\left[\frac{1}{2}\left(a+\omega^{*}+u^{*}\right)-\frac{1}{2} \alpha\left(a+\omega^{*}-u^{*}\right)+\frac{1}{2}(1-\alpha) \epsilon-\frac{1}{2}\left(a+\omega^{*}+u^{*}\right)\right]^{2}(37 \mathrm{~b}) \\
\operatorname{Var}\left(u_{\pi^{e}=0}\right)=\frac{1}{4} \sigma_{\alpha}^{2}\left(a+\omega^{*}-u^{*}\right)-\frac{1}{2} \alpha\left(a+\omega^{*}-u^{*}\right)(1+\alpha) \epsilon+\frac{1}{4}\left(1+\sigma_{\alpha}^{2}\right) \sigma_{\epsilon}^{2}(37 \mathrm{c})
\end{gathered}
$$

Then if we take the expected value of this variance, the second term including $\epsilon$ drops out: 


$$
E\left[\operatorname{Var}\left(u_{\pi^{e}=0}\right)\right]=\frac{1}{4} \sigma_{\alpha}^{2}\left(a+\omega^{*}-u^{*}\right)+\frac{1}{4}\left(1+\sigma_{\alpha}^{2}\right) \sigma_{\epsilon}^{2}
$$

In this case, unemployment volatility positively depends on the variance of $\alpha\left(\sigma_{\alpha}^{2}\right)$. An increase of $\sigma_{\alpha}^{2}$ increases both the first and the second term of equation (38).

The third case considered in section 2.1.1 was the case of perfect information about the central bank preferences. Following equation (22), the expected unemployment rate in this scenario would be:

$$
E\left(u_{P I}\right)=a+\omega^{*}
$$

Thus, the variance will be the same as in equation (35):

$$
\operatorname{Var}\left(u_{P I}\right)=\left[u_{P I}-E\left(u_{P I}\right)\right]^{2}=\left[\left(a+\omega^{*}+\epsilon\right)-\left(a+\omega^{*}\right)\right]^{2}=\sigma_{\epsilon}^{2}
$$

This means that in the case of perfect information (maximum transparency about central bank preferences), the variability of the unemployment rate only depends on fluctuations of the real economy.

On the other hand, the main argument of Sørensen (1991) is based on a situation with imperfect information about central bank preferences but rational trade unions. In this scenario, the expected unemployment rate would be:

$$
E\left(u_{E(\alpha)=0 ; E\left(\alpha^{2}\right)=\sigma_{\alpha}^{2}}\right)=\frac{a+\omega^{*}+\sigma_{\alpha}^{2} u^{*}}{1+\sigma_{\alpha}^{2}}
$$

Then, the variance is equal to:

$$
\begin{aligned}
& \operatorname{Var}\left(u_{E(\alpha)=0 ; E\left(\alpha^{2}\right)=\sigma_{\alpha}^{2}}\right)=\left[u_{E(\alpha)=0 ; E\left(\alpha^{2}\right)=\sigma_{\alpha}^{2}}-E\left(u_{\left.E(\alpha)=0 ; E\left(\alpha^{2}\right)=\sigma_{\alpha}^{2}\right)}\right]^{2}\right. \\
& \operatorname{Var}\left(u_{E(\alpha)=0 ; E\left(\alpha^{2}\right)=\sigma_{\alpha}^{2}}\right)=\left[\frac{(1-\alpha)\left(a+\omega^{*}+\epsilon\right)+\left(\alpha+\sigma_{\alpha}^{2}\right) u^{*}}{1+\sigma_{\alpha}^{2}}-\frac{a+\omega^{*}+\sigma_{\alpha}^{2} u^{*}}{1+\sigma_{\alpha}^{2}}\right]^{2} \\
& \operatorname{Var}\left(u_{E(\alpha)=0 ; E\left(\alpha^{2}\right)=\sigma_{\alpha}^{2}}\right)=\frac{(1-\alpha)^{2} \epsilon^{2}-2(1-\alpha) \epsilon \alpha\left(a+\omega^{*}-u^{*}\right)+\alpha^{2}\left(a+\omega^{*}-u^{*}\right)^{2}}{\left(1+\sigma_{\alpha}^{2}\right)^{2}}
\end{aligned}
$$

Thus, the expected variance is:

$$
E\left[\operatorname{Var}\left(u_{E(\alpha)=0 ; E\left(\alpha^{2}\right)=\sigma_{\alpha}^{2}}\right)\right]=\frac{\left(1+\sigma_{\alpha}^{2}\right) \sigma_{\epsilon}^{2}+\sigma_{\alpha}^{2}\left(a+\omega^{*}-u^{*}\right)^{2}}{\left(1+\sigma_{\alpha}^{2}\right)^{2}}
$$

In this case, the effect of central bank opaqueness on unemployment volatility cannot easily be seen. We first have to take the derivate of (43) with respect to $\sigma_{\alpha}^{2}$ :

$$
\frac{\partial E\left[\operatorname{Var}\left(u_{E(\alpha)=0 ; E\left(\alpha^{2}\right)=\sigma_{\alpha}^{2}}\right)\right]}{\partial \sigma_{\alpha}^{2}}=\frac{\left(1+\sigma_{\alpha}^{2}\right)^{2}\left[\left(a+\omega^{*}-u^{*}\right)+\sigma_{\epsilon}^{2}\right]+2\left(\sigma_{\alpha}^{2}+1\right)\left[\sigma_{\epsilon}^{2}\left(\sigma_{\alpha}^{2}+1\right)+\left(a+\omega^{*}-u^{*}\right)^{2} \sigma_{\alpha}^{2}\right]}{\left(1+\sigma_{\alpha}^{2}\right)^{4}}
$$


It is rather helpful to simplify this expression a little:

$$
\frac{\partial E\left[\operatorname { V a r } \left(u_{\left.\left.E(\alpha)=0 ; E\left(\alpha^{2}\right)=\sigma_{\alpha}^{2}\right)\right]}\right.\right.}{\partial \sigma_{\alpha}^{2}}=\frac{\left(1-\sigma_{\alpha}^{2}\right)\left(a+\omega^{*}-u^{*}\right)^{2}-\left(1+\sigma_{\alpha}^{2}\right) \sigma_{\epsilon}^{2}}{\left(1+\sigma_{\alpha}^{2}\right)^{3}}
$$

Depending on whether the first part or the second part of the nominator is larger, an increase in $\sigma_{\alpha}^{2}$ leads to higher or lower unemployment variability. Therefore, the overall result is that central bank transparency does not always lead to higher unemployment volatility but under certain circumstances unemployment variability is lower if the central bank reduces the uncertainty regarding its preferences.

Apart from that, other have discussed the effect of transparency on unemployment volatility of GDP variability. In his paper, Sánchez (2012) shows that higher transparency in either inflation or unemployment targets decreases the variance of unemployment rates. At the same time, transparency increases the welfare of trade unions. In the model, maximum transparency minimises unemployment uncertainty and maximises the welfare of trade unions. Hoeberichts et al. (2008) analyse the effect of central bank transparency in a forward-looking New Keynesian model with asymmetric information. The authors show that output stabilisation is easier to achieve if the central bank communicates its forecast error on output. However, they also argue that this comes at the cost of more volatile inflation rates.

There are also some studies discussing the effect of central bank independence on unemployment variability. In the theoretical model of Bratsiotis and Martin (1999), the variance of the unemployment rate is positively related to the central bank's preferences for employment stability and is in most cases negatively related to the central bank's preferences for price stability. That means that central bank conservativeness would lead to lower unemployment fluctuations. In contrast, the model of Lawler (2000) suggests that in the scenario with productivity shocks, a fully conservative central bank would lead to high unemployment volatility.

Some other studies analyse the impact of central bank transparency and independence on output fluctuations. In the theoretical model by Eijffinger et al. (2000), uncertainty regarding the central bank's preferences leads to lower output volatility if supply side shocks tend to be large and if the output target of the central bank is not very ambitious. Westelius (2009) uses a NewKeynesian forward-looking framework to answer the question of how transparency in timevarying preferences of the central bank regarding output stabilisation affects the economy under discretionary monetary policy. In the model, central banks can influence inflation by addressing the output gap or by affecting inflation expectations. The output gap target is time-varying with a permanent and transitory shock. If the central bank is opaque and does not publish its output gap target, the public can guess what the output gap target is but it does not know whether part of this output gap target is due to a transitory shock. A permanent shock to the output gap target has a stronger impact on inflation expectations and, thus, on inflation. Therefore, it is unambiguously better for the central bank not to publish the output gap target if the public thinks that a large part of the change in preference is transitory. If the public assumes that a larger part of the output gap target change is more permanent than in reality, it might be useful for the central bank to be transparent as this would decrease inflation expectations. However, 
in this case an expansionary monetary policy surprise leads to a higher increase in inflation which makes it less attractive. Thus, the overall result of the paper is that central bank transparency regarding the output gap target is negative as it increases inflation and output volatility.

Muto (2013) elaborates further on this and analyses the effect of transparency regarding productivity growth on the economy. He assumes that productivity growth has a persistent and permanent component. Both the central bank and the private sector have to build expectations about productivity growth. The paper shows that transparency about the central bank's forecast is only desirable if the public assumes that the central bank's estimate about permanent productivity growth is different from their own. If the private sector initially thinks that the central bank has the same forecast as the private sector but then learn - after the central bank published its forecast - that the central bank has a different, or in their minds, "wrong" forecast, they expect the central bank to adjust monetary policy in the future after the central bank realises that its forecast is wrong. That will lead them to assume that the central bank will also make forecast errors in the future which affects their expectations about future inflation and output. Thus, transparency in terms of publishing forecasts can lead to higher inflation and output volatility depending on whether the public thinks that the central bank has the same productivity forecast as they have.

In a citizen-candidate model, Herrendorf and Neumann (2003) show that if the government can decide upon labour market and central bank independence, then it would decide for strong labour market regulation and central bank independence if supply shocks are rare and their effect is small. In such an equilibrium, central bank independence can either lead to less or more employment fluctuations so the result is inconclusive. Demertzis (2004) analyses the effect of central bank independence on output volatility in a theoretical model applying numerical simulations. The result is that central bank independence that is combined with a strong focus on price stability (conservativeness) is associated with higher output volatility.

\section{Literature Review: Empirical Evidence}

It is instructive to look at empirical studies of causes of unemployment. The theoretical models presented above only shed some light on three possible determinants of unemployment: central bank transparency, central bank independence, and centralisation of wage bargaining. We will begin with studies covering those three variables.

\subsection{Central Bank Transparency}

To the best of our knowledge, the study by Hefeker and Neugart (2014) is the only one to analyse the effect of central bank transparency on unemployment directly. The study by Grüner, Hayo, and Hefeker (2009) analyses the role of monetary policy uncertainty rather than central bank transparency. They find that monetary policy uncertainty proxied with the change of the conditional variance of the expected short-term interest rate leads to lower nominal wage growth in France, Germany, and Japan while it has no effect in the UK and the US. 
The theoretical model by Hefeker and Neugart (2014) focuses on transparency and prophesises that central bank transparency leads to higher labour market regulation and, thus, to higher unemployment rates. Using a panel data set including the years 1998 to 2006, they find that higher transparency is significantly related to higher labour market regulation. Furthermore, they find that transparency is also related to higher unemployment rates. However, the study does not control for any other factor than transparency and country and time fixed effects and may suffer from an omitted variable bias. Thus, the effect of transparency could be confounded with effects of other explanatory variables. One such variable could be central bank independence or rather central bank conservativeness. It might just be the case that more transparent central banks are also more conservative or more independent which leads to higher unemployment rates. Of course, tighter monetary policy is expected to have short-term effects on unemployment rates. ${ }^{8}$ For the case of central bank independence, this is highly relevant as several studies argue that central bank independence leads to higher unemployment. It is also well known that central bank independence and transparency are likely to be related as larger autonomy requires greater information provision in democratic systems. Therefore, a reexamination of the effect of transparency including further explanatory variables is necessary in order to isolate the effect of central bank opaqueness. We will now elaborate on which other variables might be relevant.

\subsection{Central Bank Independence}

We tackled the role of central bank independence previously. There are numerous studies analysing the relationship empirically. Bleaney (1996) analyses average unemployment rates over the periods 1973 - 1982 and 1983 - 1989 within a simple OLS framework. He does not find a significant impact of central bank autonomy on unemployment in either of those two periods. On the other hand, labour market variables, like the corporatism index, are of importance.

Surprisingly enough, Kilponen (1999) finds a negative correlation between political independence and unemployment. However, the estimation also includes a dummy variable for central banks with an explicit inflation target which may serve as a proxy for the conservatism of the central bank. This dummy variable is positively related to unemployment which is in line with the argument that more conservative central banks produce higher unemployment rates.

On the other hand, Hall and Franzese (1998) present evidence for a positive impact of central bank independence on unemployment. Using OECD data for the years 1955 to 1990, they find this positive relation for the sample period average, for mean decade values, and for annual data. Their theoretical argument points towards the combination of central bank independence and coordination of wage bargaining. In line with this argument, they find strong evidence that an interaction term between those two variables has a decreasing effect on unemployment. Accordingly, central bank independence taken separately increases unemployment whereas it decreases unemployment if it is combined with a system of coordinated wage bargaining.

\footnotetext{
${ }^{8}$ Ball (1999) argues that monetary policy also has an effect on long-term unemployment. Of course, this is in sharp contrast to the idea of a long-run Philipps curve where the unemployment rate is equal to the NAIRU. In his article, Ball (1999) finds that maximum monetary policy easing (measured by the maximum cumulative decrease in the real interest rate in the very first year of a recession) significantly decreases the NAIRU.
} 
Iversen (1998b) also emphasises the combination of independence and centralisation of wage bargaining. In his study, he uses two measures for the conservativeness of monetary policy: a hard currency index and central bank independence. He also uses an index of commodification arguing that it is not just monetary policy but also public policies that might be in favour of trade unions. The hard currency index is basically a measure for growth differences in the nominal effective exchange rate. The index of commodification is the mean value of the benefit replacement ratios and of the total public sector employment. In a dynamic OLS model, he finds that monetary non-accommodation (high value of the hard currency index) decreases unemployment but the interaction term between the hard currency index and centralisation of wage bargaining is positive. In his theoretical arguments, he elaborates that two systems are stable: centralised accommodation and de-centralised non-accommodation. The results are in line with this theory. If wage bargaining is decentralised, monetary non-accommodation leads to lower unemployment. However, monetary non-accommodation leads to higher unemployment if wage bargaining is centralised. The results are basically the same when central bank independence or the index of commodification are used instead of the hard currency index. Iversen's (1998b) study focuses on ten OECD countries classified as "organised market economies"9 over the period 1973 to 1993. In his other study, Iversen (1998a) uses data on 15 OECD countries including the period 1973 to 1993. However, he uses four-year averages instead of annual data in this study. In an estimation replicating the original Calmfors and Driffill (1988) model which includes centralisation and squared centralisation along with the hard currency index, only the hard money index is significantly related to unemployment. Surprisingly enough, the coefficient on the hard currency index is negative. When interaction terms between centralisation and non-accommodation are included, only the interaction terms between centralisation and the hard currency index are relevant but not the hard money index itself. Thus, the estimation shows that tight monetary policy is irrelevant at low levels of centralisation but it increases employment at intermediate levels of centralisation. At high levels of centralisation, non-accommodative monetary policy is related to unemployment increases. This alone tells us that it depends very much on the circumstances of whether institutions are effective and successful or not.

Analysing a data set of 18 OECD countries from 1960 to 1980, Baccaro and Rei (2007) provide ample empirical evidence that central bank independence induces higher unemployment rates. Using various panel data techniques for annual and five-year averaged data they confirm the negative effect of independence on employment. In sharp contrast to the studies mentioned above, Feldmann (2011a) finds central bank independence to be negatively related to unemployment rates and positively related to employment rates. This holds for data set of 20 industrial countries for the years 1960 to 1998. Even when controlling for factors like wage bargaining centralisation, wage bargaining coordination, tax wedge, unemployment benefits, or output gap, the estimations for both annual and five year averaged data indicate that central bank independence leads to lower unemployment. In an earlier study, Garrett and Way (1999)

${ }^{9}$ These countries are Austria, Belgium, Denmark, Finland, Germany, Japan, Netherlands, Norway, Sweden, and Switzerland. 
also find central bank independence to be negatively related to unemployment using a dynamic panel data estimation for five-year averaged data for 13 countries. ${ }^{10}$

\subsection{Coordination / Centralisation of Wage Bargaining}

The third variable of major relevance in the theoretical literature is centralisation of wage bargaining. Several studies try to analyse the effect of centralisation / coordination of wage bargaining. Iversen (1998a) and Hall and Franzese (1998) show that centralisation of wage bargaining decreases unemployment. Also Bassanini and Duval (2006) find a negative relation between centralisation and unemployment. In their paper, they use a variable that takes values from 1 to 3 where 1 stands for decentralised wage bargaining and 3 stands for centralised wage bargaining to capture centralisation.

Numerous studies include variables for coordination of wage bargaining. These studies are Nickell, Nunziata, and Ochel (2005), Griffith, Harrison, and Macartney (2007), Baker et al. (2005), and Palley (2004). Focusing on different time frames but entirely on OECD countries, they find that coordination of wage bargaining is negatively related to unemployment rates. The first three papers mentioned above use the same index of coordination with values 1 (low), 2 (intermediate), and 3 (high coordination). Palley (2004) uses an index with values from 2 (low) to 6 (high). Felbermayr, Prat, and Schmerer (2011) use a dummy variable for countries with high corporatism and find that it decreases unemployment for OECD countries.

Union density might also be related to the concept of centralisation of wage bargaining. It is reasonable to assume that union power increases with the percentage of workers being members of unions. ${ }^{11}$ More members means higher membership fees which increases the bargaining power of the union basically because they can finance strikes more easily. ${ }^{12}$ However, union density does not tell us much about whether coordination between unions and policy makers is more likely. It could well be the case that union density is high but there are many trade unions so every union only cares about their utility and does not take into account the overall effect on the economy. As Golden (1993) plausibly argues, coordination between unions is more likely if the number of unions is low. Cukierman and Lippi (1999) argue that there is a competition effect and a strategic effect regarding the number of trade unions. The competition effect means that the market power of each union decreases should the number of unions decline. At the time, there is also a strategic effect as trade unions incorporate the effect of their decisions on the economy. If the number of trade unions decreases, the unions care less about the effect of their actions. Thus, the strategic effect works in the opposite direction compared to the

\footnotetext{
${ }^{10}$ According to Feldmann (2011a), an explanation for this result might be that inflation reduces lower labour supply. Cooley and Hansen (1989) present a real business cycle model with a cash-in-advance constraint where inflation leads to lower employment in the long-run. They also show that for a number of 23 countries average inflation and employment over the period 1976 to 1985 were negatively correlated.

${ }^{11}$ According to Botero et al. (2004), union density might not just increase the power of unions in the wage bargaining process but also their influence on political decisions. When they estimate the determinants of labour market regulation, their result is that union density is positively correlated with employment protection, collective relations laws, and social security laws.

12 In a general equilibrium model, Layard, Nickell, and Jackman (2005) show that equilibrium unemployment is higher, the larger the power of the trade union. This comes from the fact that the equilibrium wage also positively depends on union power.
} 
competition effect. If the number of unions goes to infinity, we basically end up with perfect competition. Therefore, the effect of union density is not unambiguous from a theoretical point of view. Empirical studies find either no effect of union density (Iversen, 1998a) or they find that union density increases unemployment (e.g. Nickel, 1997; Blanchard and Wolfers, 2000). Dutt, Mitra, and Ranjan (2009) employ the union power measure by Botero et al. (2004). This variable is the mean of seven dummy variables that try to capture the influence of unions in the wage bargaining process. Dutt, Mitra, and Ranjan (2009) show that union power leads to higher unemployment rates.

Kilponen (1999) emphasises that union density and union coverage might differ substantially. Accordingly, union coverage is a better measure for the market power of unions as it measures how many workers are affected by decisions of trade unions. Union coverage is directly included in the study of Palley (2004) which concludes that union coverage increases unemployment. In Kilponen's (1999) estimations, neither union density nor union coverage have an effect on unemployment. Instead he uses the difference between coverage and density to capture the free rider problem that arises from the fact that some workers benefit from union's decisions even though they are non-members. The coverage-density-differential is positively related to unemployment.

\subsection{Labour Market Regulation}

There is an ongoing discussion about the role of labour market institutions. Following Freeman (1992), there are two schools: institutionalism and distortionism. Where the first school argues that institutions can counter market imperfections, the latter views institutions as efficiency decreasing. We already tackled the role of the wage bargaining process and that of unions. However, there are some other factors that might also be relevant. Labour market regulation is seen as one of the driving forces of unemployment. On the one hand, legislation like employment protection might hinder employers to lay off workers. On the other hand, such regulation might reduce the employers' willingness to hire new workers as it may be difficult to fire them later. This might make employers cautious with respect to hiring new staff. Minimum wages could also play a role. Clearly, a national minimum wage would not be effective if it is lower than the equilibrium wage. In this case, the minimum wage should not have an effect on employment. If the minimum wage is at least as high as the current wage rate, then it depends on the market type whether it increases or decreases employment. In a monopsony, i.e. in a market where there is a limited amount of employers that have direct influence on wages, a minimum wage might actually be employment increasing. However, an effective minimum wage would reduce employment and create involuntary unemployment given perfect competition. The monopsony might be the appropriate model for local labour markets.

Using the labour market regulation index of the Fraser Institute, Felbermayr, Prat, and Schmerer (2011) present direct empirical evidence that labour market regulation increases unemployment. Several studies capture the effect of employment protection by including the respective OECD variable. For instance, Bassanini and Duval (2006) and Blanchard and Wolfers (2000) show that employment protection increases unemployment in OECD countries. 
Di Tella and MacCulloch (2005) use an indicator for labour market flexibility based on a survey that is strongly correlated with the OECD employment protection measure. According to their estimations, higher labour market flexibility leads to lower short-term and long-term unemployment. On the other hand, some studies find that employment protection does not affect unemployment (e.g. Nickell et al., 2005) but rather reduces unemployment (e.g. Garibaldi and Violante, 2005).

Bassanini and Duval (2006) also assess the role of minimum wages and find that both minimum wages and an interaction term between minimum wages and the tax wage increase unemployment.

Apart from that, social security regulation plays a role. Unemployment benefits increase nonlabour income and thus reduce opportunity costs of leisure. There is a great deal of empirical evidence that unemployment benefits increase reservation wages (e.g. Brown and Taylor, 2013). In addition, benefit duration might be influential. The longer someone receives unemployment benefit, the longer he or she can search for a new job. Therefore, we would expect that both the amount of unemployment benefits and its duration might increase unemployment as both decrease the pressure to accept any given job offer. Belot and van Ours (2004) are among the authors that find that higher average replacement rates induce higher unemployment rates. Nickell, Nunziata, and Ochel (2005) confirm that benefit duration, too, increases unemployment rates.

The idea of a Beveridge curve delivers an argument for active labour market policies (e.g. trainings for workers). ${ }^{13}$ Accordingly, such policies might improve the matching efficiency by reducing skill mismatches and increasing job stability. Nickel (1997) and Blanchard and Wolfers (2000) confirm these considerations empirically showing that active labour market policies decrease unemployment rates.

\subsection{Government Taxes}

Governments can affect employment not only through labour market regulation but also through tax regulation. Textbook economics tells us that labour taxes decrease employment no matter whether employers or employees have to pay the tax. To put it quite simply, wagedependent levies decrease the opportunity costs of leisure. Consumption taxes might have a similar effect as they decrease the purchasing power of the take home pay. They might dampen aggregated demand and, thus, labour demand. Daveri and Tabellini (2000) present empirical evidence for the hypothesis that the total employment tax rate reduces employment. Nickell, Nunziata, and Ochel (2005) use the labour tax rate and come to the same conclusion that labour taxes increase unemployment. The tax wedge includes both employers' and employees' contributions. Thus, it is basically the difference between labour costs and the net salary of employees. Belot and van Ours (2001) are among the papers which show that the tax wedge is positively correlated to unemployment rates. Bassanini and Duval (2006) show that the consumption tax rate has the same effect as labour taxes.

\footnotetext{
${ }^{13}$ This model might also explain why the owner occupation rate is positively correlated with unemployment (Nickel, 1997). A high owner occupation rate might reduce labour mobility within a country and, thus, increase regional mismatches.
} 


\subsection{Other Government Policies}

Two other important areas where governments might also have something to say are product market regulation and trade policy. The effect of product market regulation is straight forward. ${ }^{14}$ Market regulation (e.g. entry barriers) increase the market power of incumbent firms. Take for instance a monopoly: in such a market the price is higher and the output is lower compared to perfect competition. Lower output also means that fewer workers are needed. Griffith, Harrison, and Macartney (2007) proxy product market regulation with mean firm profitability in the respective economy. Their result is that higher profitability (i.e. lower product market competition) is related to higher unemployment. Felbermayr, Prat, and Schmerer (2011) take the Fraser Institute measure of product market regulation and find that higher regulation raises unemployment rates.

Dutt, Mitra, and Ranjan (2009) explore the trade-unemployment relation both theoretically and empirically. According to them, Ricardian advantage would unanimously decrease unemployment while the Heckscher-Ohlin model predicts that trade would raise employment only in the labour-abundant country. Empirically they find that a country's unweighted tariff, its overall trade restrictiveness, its trade barriers according to the Global Competitiveness Report, and its import duty are all positively related to unemployment. Thus, there is overwhelming evidence for the Ricardian hypothesis. Felbermayr, Prat, and Schmerer (2011) explore the impact of trade openness. They find strong evidence that overall trade openness reduces unemployment. It is important to note that they use five year averaged data to get rid of short-term cyclical effects. On the other hand, Iversen (1998a) argues that the effect of openness is unclear. Openness could decrease unemployment as it disciplines agents due to the negative effects of losing price competitiveness. However, openness might increase competition and could increase unemployment of low-skilled workers. ${ }^{15}$ Using annual data, he finds that trade openness increases unemployment. Also Hall and Franzese (1998) come to the same conclusion when using annual data. At the same time, trade openness might also increase the need for labour market regulation. Showing some scatterplots, Agell (1999) confirms that for European countries trade openness and labour market regulation are positively related.

So far we have seen that less regulation of product markets, labour markets, and trade might be helpful in reducing unemployment. However, Dutt, Mitra, and Ranjan (2009) point out that civil liberties might also be relevant. When including the Fraser Institute measure of civil liberties, they find that higher civil liberties are related to lower unemployment rates.

Finally, governments might increase employment in the short-run by simply hiring people to the public service. As Griffith, Harrison, and Macartney (2007) show, the public sector employment rate is negatively related to unemployment rates.

\footnotetext{
${ }^{14}$ Blanchard and Giavazzi (2003) derive a theoretical model that shows that product market regulation increases unemployment.

${ }^{15}$ In the original source, Wood (1995) explains that the reduction of labour demand of low-skilled workers only leads to higher unemployment among these people if there are some downward (relative) wage rigidities.
} 


\subsection{Macroeconomic Effects}

When looking at short-term unemployment rates, macroeconomic effects play a role. We can derive from a simple AS-AD or Philipps curve model that fluctuations in the aggregated demand lead to output and unemployment changes assuming that prices and wages are to some extent sticky. Therefore, monetary or fiscal policy variables might be related to unemployment. In the long-run, shifts of only the long-run AS curve can affect output and employment.

The negative effect of the output gap ${ }^{16}$ on unemployment rates is confirmed by several studies, e.g. by Griffith, Harrison, and Macartney (2007). Palley (2004) uses GDP growth and comes to the same conclusion that GDP growth leads to higher employment. Following the short-term Philipps curve, an increase in inflation should be related to declining unemployment. ${ }^{17}$ Palley (2004) and Baker et al. (2005) include the change in inflation in their estimations and confirm this presupposition. On the other hand, restrictive monetary policy should decrease inflation and output in the short-term. Bassanini and Duval (2006) include a variable covering real interest rate shocks where this variable is defined as the difference between yields on 10 year nominal government bonds and annual inflation. They further elaborate that real interest rate shocks might force companies to reduce their capital stock which results in lower labour productivity and employment. Empirically, they can underpin this hypothesis. Nickell, Nunziata, and Ochel (2005) as well as Palley (2004) include real interest rates in their estimations. The result is that higher real interest rates enlarge unemployment rates. Turning to the labour market: here it is mainly labour demand that drives employment in the short-run. Both Nickell, Nunziata, and Ochel (2005) and Bassanini and Duval (2006) confirm the role of labour demand shocks. Although it is central to the question of unemployment, the role of wages is somewhat unclear. We would expect a negative impact of wage increase on employment only if unit labour costs increase. If real wages increase as a result of labour productivity or labour demand surges, unemployment is not expected to increase. Kilponen (1999) analyses the impact of real wage growth. In his study, real wage growth is related to unemployment decreases. This indicates that real wage growth might indeed capture business cycle effects.

Apart from that, external effects could also affect short-term output and unemployment. Lower export demand decreases aggregated demand and, thus, output. Iversen (1998a) uses the average OECD unemployment rate to capture a world-wide effect. This variable is positively correlated with domestic unemployment. In his other study, Iversen (1998b) uses the yearly growth in the export market. Higher GDP growth in the most relevant export markets decreases domestic unemployment as those foreign countries import more if their income increases. An increase in the terms of trade is expected to induce a decline in unemployment. Textbook economics argues that an increase in terms of trade is equivalent to an increase in welfare. Kose (2002) employs a dynamic stochastic business cycle model to analyse the role of price shocks. According to him, almost $90 \%$ of output fluctuations in developing countries can be explained by world price shocks. Hall and Franzese (1998) include terms of trade in their estimations

\footnotetext{
${ }^{16}$ In this case, the output gap is defined as difference between actual output and potential output.

17 The total inflation rate might be related to higher unemployment. Several studies show that high inflation is detrimental for GDP growth. For instance, Kremer, Bick, and Nautz, (2013) find a negative impact of inflation on GDP growth if inflation rates are higher than $2.5 \%$ in industrialised countries and $17 \%$ in developing countries.
} 
where terms of trade are computed as the quotient of an export price index and an import price index. The result is that deteriorating terms of trade increase unemployment but the product of openness and terms of trade decrease unemployment. Thus, the effect of terms of trade is contingent on trade openness. Bassanini and Duval (2006) use a variable capturing terms of trade shocks where this variable is defined as the product of the logarithm of import price changes divided by domestic inflation multiplied with the amount of nominal imports as a percentage of nominal GDP. The result is that terms of trade shocks lead to higher unemployment. Griffith, Harrison, and Macartney (2007) find that an appreciation of the real exchange rate tends to lower unemployment rates.

We argued before that increases in productivity should increase output and diminish unemployment. Nickell, Nunziata, and Ochel (2005) point to the role of TFP shocks. Accordingly, TFP shocks induce employment upsurges. In an empirical study, the International Monetary Fund (2003) confirms that labour productivity growth decreases unemployment.

Overall, domestic market size of an economy might be another relevant factor. Felbermayr, Prat, and Schmerer (2011) use the logarithm of population to account for market size. Accordingly, a larger domestic market (larger population) is related to lower unemployment rates. When analysing Latin American unemployment rates, Ball, De Roux, and Hofstetter (2013) find that GDP per capita is positively correlated and rural population is negatively correlated with unemployment. Of course, both variables are strongly correlated themselves. The story behind that is that, in general, rural areas tend to have lower official unemployment rates.

\subsection{Volatility of Inflation and Exchange Rates}

There are two other macroeconomic variables that might be of utmost importance for the research question of this article. These are inflation volatility and exchange rate volatility. The hypothesis that inflation variability leads to higher unemployment was initially put forth by Friedman (1977) in his Nobel Prize Lecture. His main arguments are that inflation variability affects the optimal length of contracts and it distorts the information function of (relative) prices. In the same manner, Reagan and Stulz (1993) argue that inflation volatility increases contracting costs and, thus, reduces output. Other arguments would be that inflation uncertainty makes agents more cautious as they are concerned about potential redistribution effects if their inflation projections were wrong. Therefore, as Seyfried and Ewing (2001) argue, agents might spend a lot of time gathering and processing price information which hampers economic activity. Seyfried and Ewing (2001) also analyse the hypothesis empirically. They look at G7 countries using quarterly data. Inflation variability is defined as the eight quarter standard deviation of inflation. In estimating Engle-Granger tests for cointegration, they find that inflation variability Granger causes unemployment in four out of seven countries. Feldmann (2012) elaborates further on this issue. He analyses the effect of inflation volatility on 20 industrial countries. In his study, inflation variability is defined as the five year standard deviation of percentage changes in the annual GDP deflator. Controlling for a multitude of variables, he finds that inflation volatility both in the range of one to five years ago as well as six to ten years ago leads to higher unemployment rates. Cunningham et al. (1997) deliver both 
a literature review on other studies confirming the positive relation between inflation uncertainty and unemployment as well as some of their own empirical evidence for the detrimental effect of inflation volatility on unemployment in the case of the United States.

When contemplating the role of exchange rate volatility, an initial thought might be that exchange rate volatility is detrimental to trade. There is strong evidence that having a common currency or forming a currency union is beneficial for trade (Yeyati, 2003). Belke and Setzer (2003) present a theoretical model that hypothesises that exchange rate variability makes firms reluctant to hire workers. Instead they wait until they hire new workers. The result is higher unemployment. For instance, Belke and Gros (2002a) present empirical evidence that variability of the Euro-Dollar exchange rate significantly increases unemployment in the US and the Eurozone. Belke and Gros (2002b) look at Brazil and Argentina. Their finding is that variability of the domestic exchange rate with respect to the US Dollar and the Euro are significantly related to higher unemployment rates in Brazil and Argentina. Analysing a panel data set of 17 industrial countries, Feldmann (2011b) confirms that real effective exchange rate volatility (measured on the basis of a $\operatorname{GARCH}(1,1)$ model) is positively linked to unemployment rates.

Inflation variability and exchange rate variability might be highly relevant as central bank transparency could have an influence on those two variables. There is at least some evidence that central bank transparency might reduce inflation volatility (Demertzis and Hallett, 2007). Therefore, it is reasonable to assume that these are two relevant channels through which central bank transparency can affect unemployment rates.

\subsection{Determinants of Unemployment Volatility}

The literature on unemployment volatility is relatively scarce. To the best of our knowledge, there is only one study analysing the effect of monetary policy uncertainty on unemployment fluctuations. Using a VAR model with ARCH shocks, Herro and Murray (20113) show that output growth and unemployment are more volatile if the stance of monetary policy is more uncertain. Revisiting Rogoff's (1993) argument that central bank independence increases unemployment fluctuations, Alesina and Summers (1993) consider the impact of independence on the variance of unemployment rates for a sample of 16 countries. According to their estimation, the relationship between central bank independence and the variance of unemployment rates is weak. Apart from that, the majority of studies focuses on the effects of labour market regulation on unemployment variability. Sala et al. (2012) find that employment protection of permanent contracts in OECD countries is negatively related to unemployment volatility in the period $1970-1990$ but it is positively correlated in the period $1991-2006$. Employment protection of temporary contracts is weakly positively related to unemployment volatility in the first period while it is strongly negatively correlated in the latter period. Abbritti and Weber (2010) confirm that employment protection reduces unemployment volatility for a data set of 19 OECD countries (1970-1999). Furthermore, unemployment benefits, the benefit replacement rate, benefit duration, the tax wedge, and decentralised wage setting are positively related to unemployment fluctuations. Faccini and Rosazza Bondibene (2012) deliver slightly different results. According to them, employment protection of permanent contracts reduces 
unemployment volatility relative to GDP per capita volatility. They also find that benefit duration and the tax wedge reduce unemployment fluctuations. In addition, they show that union density has a decreasing effect on unemployment variability while union coverage tends to increase volatility. Lochner (2014) finds a non-linear effect of employment protection on unemployment volatility relative to GDP per capita volatility. Furthermore, his analysis provides evidence that coordination of wage bargaining, union density, the replacement rate, the real interest rate, and government size all decrease unemployment fluctuations. In contrast to these findings, de Serres and Murtin (2013) argue that benefit duration, employment protection, and product market regulation are associated with larger unemployment volatility.

To the best of my knowledge, the effect of central bank transparency on unemployment volatility has not yet been analysed so far. There are only a few studies discussing the effect of transparency on output volatility. Dincer Eichengreen (2007) show that central bank transparency reduces output volatility. Fatás and Mihov (2007) find that transparency about the central bank goals has either no significant effect on output volatility or it decreases output volatility. On the other hand, Demertzis and Hallett (2007) find that the effect of transparency on output volatility is ambiguous with the tendency for transparency to raise output fluctuations.

\section{Data and Methodology}

\subsection{Data}

Our data on central bank transparency (CBT) and independence comes from Dincer and Eichengreen (2014). There are several ways of measuring those two variables. The most commonly used index for CBT is the Eijffinger-Geraats-Index (Eijffinger and Geraats, 2006). This index has five dimensions: political transparency, economic transparency, policy transparency, operational transparency, and procedural transparency. Each of these dimensions has three categories. In each category, a $\mathrm{CB}$ can reach a maximum value of one. Thus, the maximum value per dimension is three and the range of the index is $[0,15]$. The measure for central bank independence (CBI) is Cukierman's unweighted index of de jure central bank autonomy (for detailed information see Cukierman, 1992). The index has four dimensions focussing on the selection of personnel, the right to conduct monetary policy, the objectives of the $\mathrm{CB}$, and rules on government financing. The range of the index is zero to one where one means maximum autonomy.

In general, we use two approaches to measure the effect of CBT on unemployment. Firstly, we analyse the direct effect of CBT on unemployment where unemployment is measured by the number of unemployed people as a percentage of the total labour force (ILO definition). We use the modelled ILO estimate. Secondly, we are interested in the impact of CBT on wages as most theoretical models argue that the effect of CBT on unemployment goes through wages. Here we use two data sets: ILO data and the occupational wages around the world (OWW) database (Oostendorp, 2012). The latter is a data collection based on the October Inquiry of the ILO which standardises the data. Here we do not distinguish between different industries nor 
between various occupations but use either the mean or the median wage over all industries per year. Thirdly, we consider the impact of CBT on unemployment volatility. For this purpose, we use a combination of data from the International Monetary Fund and national bureaus of statistics. This allows us to analyse the effect for a maximum of 94 countries while most studies use OECD data that provides statistics for only 37 countries. Unemployment volatility is defined as the standard deviation of the quarterly unemployment rate within a given year.

Apart from that, we use macroeconomic data from the World Development Indicators and International Financial Statistics. Political variables are captured by the Worldwide Governance Indicators data base, Freedom House, and the Polity IV data set. The most critical points are indicators of labour market institutions and regulations. Most studies rely on OECD and ILO data. However, this would shrink the number of countries substantially. Therefore, we employ some other data sets, too. The Fraser Institute publishes an annual report on economic freedom of the world (Gwartney, Lawson, and Hall, 2014). This data is available on an annual basis from 2000 to 2010 and includes variables on credit, product, and labour market regulation but also on tariffs and trade barriers. Visser (2015) provides a data base including various measures of labour market features. Among these are characteristics of wage setting, minimum wages, union density, and many others. This data set delivers observations for a maximum time span from 1960 to 2011. However, it only includes 48 countries. Aleksynska and Schindler (2011) offer an intriguing data base including a maximum of 91 countries for the time period of 1980 to 2005. Given that the data on central bank transparency and inflation is only available from 1998 to 2010, this reduces the maximum amount of observations. If we employ data by the Fraser Institute, the estimation period is 2000 to 2010. If we use Visser's data (2015), we can look at the entire 1998 - 2010 sample but only regarding a reduced number of countries. When we want to use the IMF data by Aleksynska and Schindler (2011), we can only analyse the years 1998 to 2005 . Thus, we cannot easily compare different estimations as the time periods and countries under study differ when applying different data sets. Summary statistics of the most important variables are presented in the appendix (Table A.7).

\subsection{Empirical Strategy}

With annual panel data, there are two main techniques that we can apply: fixed effects and random effects.

$$
\begin{aligned}
& w_{i t}=\vartheta_{i}+\tau_{t}+\beta_{0}+\sum_{k=1}^{m} \beta_{k} Q_{k i t}+\varepsilon_{i t} \\
& U_{i t}=\vartheta_{i}+\tau_{t}+\beta_{0}+\sum_{k=1}^{m} \beta_{k} X_{k i t}+\varepsilon_{i t}
\end{aligned}
$$

In our case, the dependent variables are the wage $w_{i t}$ and the unemployment rate $U_{i t}$ in country $i$ at time $t . \vartheta_{i}$ are country fixed effects and $\tau_{t}$ are time fixed effects. $Q_{k i t}$ and $X_{k i t}$ are the explanatory variables. When it comes to deciding between random and fixed effects, the critical question is whether there are time-invariant factors that might be endogenous which, however, are not observable. In the case of wages, productivity is the main factor explaining differences 
in payments between countries. We capture labour productivity by including GDP per capita (as a measure for the overall development of a country) and also manufacturing value added. However, this is certainly not enough to soak up the entire effect. Thus, we stick with fixed effects estimations as there is some concern that production technology might also affect variables like GDP growth which would distort our results. In the case of unemployment, Yang and Lester (2000) emphasise that culture can affect unemployment. Culture could also influence decisions about changes in labour market regulation. Assuming that culture does not change substantially with decades, including country fixed effects should be enough to capture timeinvariant determinants of unemployment. However, we also compute random effects models and compare the suitability of the two approaches with Hausman tests. We include yearly dummies to control for worldwide macroeconomic effects like the recent financial crisis.

In order to avoid potential endogeneity problems, we include central bank transparency and independence only as lagged variables in the estimations of the determinants of unemployment. An economic justification is that increases in central bank transparency and independence might not directly affect decisions by agents as many contracts are not re-negotiated annually or investment decisions might stick for some time. Thus, we essentially estimate the following equation.

$$
U_{i t}=\vartheta_{i}+\tau_{t}+\beta_{0}+\beta_{1} C B T_{i, t-1}+\beta_{2} C B T_{i, t-1}^{2}+\beta_{3} C B I_{i, t-1}+\sum_{k=4}^{m} \beta_{k} X_{k i t}+\varepsilon_{i t}
$$

$C B T$ is the central bank transparency index value. $C B I$ is the central bank independence index. We allow that the effect of central bank transparency on unemployment is non-linear by also including CBT as squared value. When estimating non-linear effects, it is useful to consider the turning point from which on the slope with respect to the respective explanatory variable changes. In this case, the turning point is basically $\left|\frac{\widehat{\beta}_{1}}{2 \cdot \widehat{\beta}_{2}}\right|$ where $\hat{\beta}_{1}$ and $\hat{\beta}_{2}$ are the estimated coefficients of the regression. This turning point shows the value at which the maximum (minimum) is reached. If $C B T$ reaches a value of $\left|\frac{\widehat{\beta}_{1}}{\widehat{\beta}_{2}}\right|$, the net effect of $C B T$ would be zero. Only for cases in which $C B T>\left|\widehat{\beta}_{1}\right|$ would the overall effect of transparency become negative.

There is good reason to believe that unemployment is persistent. Bean (1994) points to demand and supply side reasons. Demand side explanations for persistence in unemployment are that hiring workers for a short period of time might be unattractive due to high hiring and firing costs and that capital endowment is inflexible in the short-term. Supply side effects arise from insider-outsider theory. Insiders (i.e. current workers) have a stronger influence on wage bargaining. Furthermore, unemployed people might get detached from the labour market because employers do not want to hire long-term unemployed people or because the willingness to search for jobs goes down with time as workers get frustrated by constant rejections. Of course, the usual assumption is that workers lose human capital the longer they are unemployed. This would call for a dynamic panel data model of the following form:

$$
U_{i t}=\vartheta_{i}+\tau_{t}+\beta_{0} U_{i, t-1}+\beta_{1} C B T_{i, t-1}+\beta_{2} C B T_{i, t-1}^{2}+\beta_{3} C B I_{i, t-1}+\sum_{k=4}^{m} \beta_{k} X_{k i t}+\varepsilon_{i t}
$$


An estimation of this model with fixed effects would lead to the well-known dynamic panel bias. A readily available solution to the problem is to use GMM. Here we use difference GMM where we instrument the lagged unemployment rate with the unemployment rate from two years ago. The main assumption of this approach is that there is no second or higher order correlation in first differences of the error term.

$$
E\left(U_{i, t-s} \Delta \varepsilon_{i, t}\right)=0 \quad \forall i, t \text { and } s=2, \ldots, T
$$

We can test this assumption empirically with the Arellano and Bond (1991) test for serial correlation. Furthermore, it is possible to test the exogeneity of the employed instrumental variables with Hansen's j-statistic.

The previously described estimation techniques estimate the effect of CBT on wages and unemployment separately. However, it would make sense to consider both variables at the same time. Theoretical considerations suggested that the channel through which CBT works is the wage channel. We also try to test this hypothesis empirically. The logic is straightforward: transparency affects wages which should in turn lead to higher or lower unemployment. This calls for a simultaneous equation model. Equations 39 and 40 summarise the theoretical considerations:

$$
\begin{aligned}
& w_{i, t-1}=\vartheta_{i}+\tau_{t-1}+\beta_{0}+\beta_{1} C B T_{i, t-1}+\sum_{k=2}^{m} \beta_{k} Q_{k, i, t-1}+\varepsilon_{i, t-1} \\
& U_{i, t}=\vartheta_{i}+\tau_{t}+\beta_{0}+\beta_{1} w_{i, t-1}+\beta_{2} C B T_{i, t}+\sum_{k=3}^{m} \beta_{k} X_{k, i, t}+\varepsilon_{i, t}
\end{aligned}
$$

In our case, the focus is on average wages of the previous period $\left(w_{i, t-1}\right)$. The reason behind that is that there is some concern that unemployment has an effect on wages. Thus, we only include wages as lagged variables. This should eliminate the problem as unemployment rates of the current period should not have a direct impact on wages of the previous period. All explanatory variables of the first stage including transparency $\left(C B T_{i, t-1}\right)$ are also lagged. In addition to transparency, some other factors $Q_{k, i, t-1}$ might influence inflation expectations. The wages themselves affect the unemployment rate of the current period $\left(U_{i, t}\right)$. Standard neoclassical economics would suggest that ceteris paribus an increase in wages is followed by a decrease of employment. An appropriate econometric approach to estimate such a mechanism is a simultaneous equation model. Here we use two stages least squares (TSLS) estimations.

\section{Estimation Results}

After discussing theory, empirical evidence and the data set we use, we can now turn to the empirical part of the article. Firstly, it will be shown what the effect of CBT on wages is. Secondly, the relationship between CBT and unemployment is examined. Finally, we combine both approaches to find the mechanism through which CBT influences unemployment. 


\subsection{Transparency and Wages}

The theoretical literature that argues against higher CBT (see section 2.1.1 and 2.1.2) justifies its reasoning with the result that $\mathrm{CBT}$ would lead to higher wages which results in higher unemployment. Thus, it is useful to assess whether this assumption holds true. In the analysis we use various wage measures out of two data sets to estimate the effect. The results of the estimations are presented in Table 1. Additional estimations are presented in the Appendix (Table A.1).

Table 1: Determinants of Annual Wages

\begin{tabular}{|c|c|c|c|c|c|c|c|c|c|}
\hline Variable & wa1 & wa2 & wa3 & wa4 & wa5 & wa6 & wa7 & wa8 & wa9 \\
\hline Dep. Var. & real_mthly_earnings & real_mthly_earnings_gr & hw2wuus ${ }^{1}$ & hw3wuus ${ }^{1}$ & hw3wuus $^{1}$ & hw4wuus ${ }^{1}$ & hw2wlus ${ }^{1}$ & hw3wlus ${ }^{1}$ & hw4wlus $^{1}$ \\
\hline$\overline{\mathrm{CBT}}$ & $-12996.02 * *$ & $-1.73^{*}$ & $-1.59^{* * *}$ & $-0.22^{*}$ & $-1.21 * * *$ & $-1.22 * * *$ & $-1.58 * * *$ & * $\quad-1.20 * * *$ & * $\quad-1.22 * * *$ \\
\hline $\mathrm{CBT}^{2}$ & & & $0.11^{* * *}$ & & $0.08^{* * * *}$ & $0.08 * * *$ & $0.10^{* * * *}$ & $0.08 * * *$ & $0.08 * * *$ \\
\hline $\mathrm{CBI}$ & -98969.54 & $41.44 * *$ & $7.62 * * *$ & $7.01 * * *$ & $7.64^{* * *} *$ & $9.76^{* * *}$ & $7.71 * * *$ & $7.74 * * *$ & $9.87 * * *$ \\
\hline GDP per capita & $0.05 * * *$ & 0.00 & $0.00 *$ & $0.00^{* *}$ & $0.00 * *$ & $0.00 *$ & $0.00 *$ & $0.00 *$ & $0.00 *$ \\
\hline GDP Growth & $-2593.43^{* *}$ & $0.59 * * *$ & -0.01 & $-0.08 * *$ & -0.03 & -0.03 & -0.01 & -0.03 & -0.03 \\
\hline $\begin{array}{l}\text { Growth in Manufacturing } \\
\text { Value Added }\end{array}$ & -62.37 & & 0.02 & & 0.00 & 0.00 & 0.02 & 0.00 & 0.00 \\
\hline Constant & $112284.74 * *$ & 0.00 & $5.25 * * *$ & $2.23 * * *$ & $4.47 * * *$ & $3.63 * * *$ & $5.20 * * *$ & $4.42 * * *$ & $3.60 * * *$ \\
\hline $\mathrm{N}$ & 191 & 248 & 170 & 278 & 243 & 243 & 170 & 243 & 243 \\
\hline Groups & 19 & 53 & 28 & 44 & 39 & 39 & 28 & 39 & 39 \\
\hline $\mathrm{F}$ & 12.06 & 5.26 & 9.87 & 17.72 & 13.86 & 13.1 & 9.74 & 13.75 & 13.06 \\
\hline $\mathrm{R}^{2}$ & 0.57 & 0.22 & 0.56 & 0.53 & 0.54 & 0.53 & 0.55 & 0.54 & 0.53 \\
\hline
\end{tabular}

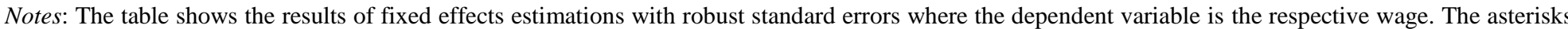
indicate whether a coefficient is significantly different from zero $10 \%$ (one asterisk), $5 \%$ (two asterisks) or $1 \%$ (three asterisks) significance level.

All estimations use fixed effects estimations where the dependent variable is the respective wage measure. ${ }^{18}$ In the basic setting, the explanatory variables are CBT, CBI, GDP growth, and GDP per capita. Rodrik (1999) uses a similar setting. He argues that GDP per capita should be included in addition to the country dummies to capture different developments of production technologies. In fact, we find that GDP per capita is significantly and positively related to wages in most estimations. Apart from that, we include GDP growth which should have a positive impact on wages. In a simple neoclassical model an increase in production due to higher aggregated demand leads to an increase of labour demand. The result is higher employment and higher wages. However, in some estimations the coefficient of GDP growth ${ }^{19}$ is negative which is astonishing. A plausible explanation for this phenomenon is the composition effect. In a recession, low paid workers are usually the first to be laid off. Looking at average wages the proportion of high paid workers increases which leads to an increase in the average wage paid in a particular country. On the other hand, the proportion of low paid employees increases in an economic upswing which might lead to a decrease in average wages in the short term (ILO, 2014). Productivity changes are captured by the growth in manufacturing value added. While we also tried other measures like growth in service value added, only manufacturing value added mattered. This variable seems to have a positive impact on wages which is in line with theoretical assumptions that say that workers should be compensated for labour productivity increases.

\footnotetext{
${ }^{18}$ The definitions of the different wage measures are available in the Appendix.

${ }^{19}$ Concerns that it is not necessary to include GDP growth in addition to GDP per capita are groundless with respect to the effect of central bank transparency. With only one exception the exclusion of GDP growth from the regressions does not affect the significance of the coefficient of central bank transparency.
} 
The main variables of interest are CBT and CBI. These are either included as current or lagged values. The overall picture is that CBT either has no impact on wages or it decreases wages. In some cases the effect seems to be non-linear as indicated by the inclusion of squared CBT. On the other hand, CBI tends to be positively correlated with wages. This comes as no surprise as this result is in line with the theoretical assumptions. Central bank conservativeness leads to higher wages while CBT can reduce the negative effect of CBI. The sole problem is that many theoretical articles do not distinguish between central bank independence and transparency.

Therefore, the first intermediate result is that the presumption that CBT leads to higher wages is not supported by the empirical estimations. In fact, many estimations would rather suggest that CBT is related to lower wages. This leads to the question of what effect CBT has on unemployment.

\subsection{Transparency and Unemployment}

Before we turn to the panel estimations, it is instructive to have a look at some descriptive statistics and sample averages. The data set includes a maximum of 108 countries.

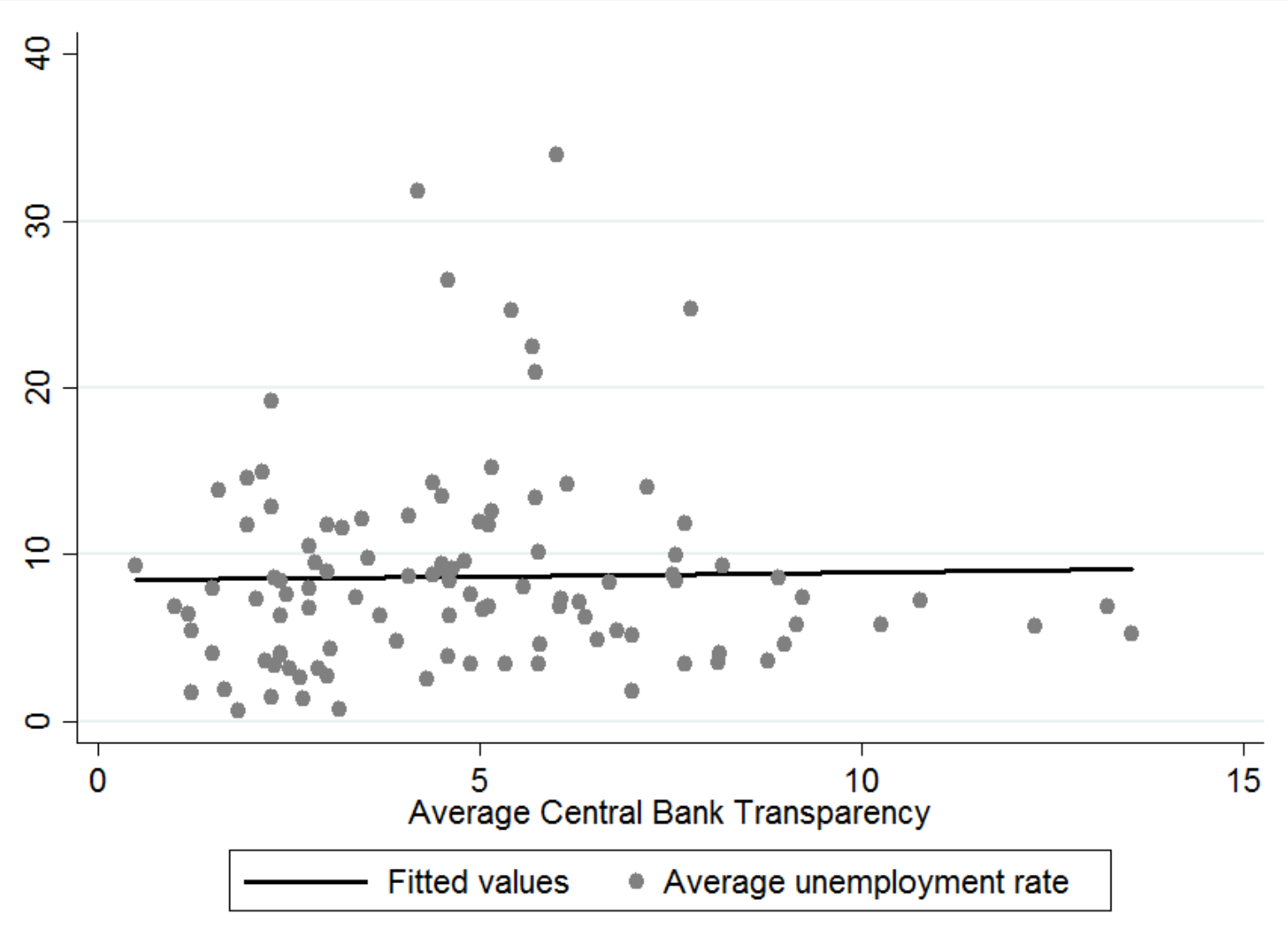

Figure 1: Central Bank Transparency and Unemployment (1998-2010 means)

Figure 1 shows a scatter plot of average transparency and unemployment rates over the period 1998 to 2010. There is only a weak positive relation between transparency and unemployment. However, correlation does not control for other factors affecting unemployment. The results of 
multivariate regressions using country averages are presented in Table A.2 in the Appendix. Even after checking for several other factors central bank transparency still has a positive effect on unemployment in most estimations. Here we control for macroeconomic effects (money growth, GDP growth, inflation, terms of trade, exchange rate growth), for overall development (GDP per capita), domestic market size (population) and for several variables capturing labour market regulation. In these estimations, there are hardly any variables with significant impact on unemployment. GDP growth and GDP per capita are among the variables with some explanatory power. Surprisingly, broad money growth is positively related to unemployment. However, this could also be the result of reverse causality resulting from the fact that countries with high unemployment rates might be tempted to conduct expansionary monetary policy in order to stimulate the economy.

One of the problems of this simple estimation is that we cannot control for unobservable timeinvariant factors affecting unemployment. This is something we can do in a panel data estimation with fixed effects. Thus, we will now turn to the panel data estimations presented. The main results are presented in Table 2. Additional robustness checks including further explanatory variables are shown in the Appendix in Table A.3.

\section{Table 2: Determinants of Unemployment}

\begin{tabular}{|c|c|c|c|c|c|c|c|c|}
\hline Variable & fe1 & fe2 & fe3 & fe4 & fe5 & fe6 & fe7 & fe8 \\
\hline$\overline{\text { CBT }}$ & $-0.77 * * *$ & $k_{-0.66 * *}$ & $-0.7 * * *$ & $*_{-1.39 * * *}$ & $-1.25 * * *$ & $*_{-} 1.35 * * *$ & $-1.25 * * *$ & $*-1.14 * * *$ \\
\hline $\mathrm{CBT}^{2}$ & $0.05 * * *$ & $0.05 * * *$ & $* 0.05 * * *$ & $* 0.09 * * *$ & $0.08 * * *$ & $* 0.08 * * *$ & $=0.08 * * *$ & $* 0.07 * * *$ \\
\hline CBI & $3.42 * *$ & $4.43 * *$ & $4.47 * *$ & $11.2 * * *$ & $12.2 * * *$ & * $14.7 * * *$ & $10.3 * * *$ & * $11.8 * * *$ \\
\hline Inflation & -0.01 & -0.05 & -0.04 & $-0.04-$ & $-0.09 * *$ & -0.04 & -0.05 & $-0.1 * *$ \\
\hline Terms of Trade & 0.00 & 0.00 & 0.00 & 0.01 & 0.01 & 0.01 & $0.02 *$ & $0.02 *$ \\
\hline Real Interest Rate & -0.01 & -0.01 & 0.00 & 0.00 & 0.00 & 0.01 & 0.00 & 0.00 \\
\hline GDP Growth & $0.03 *$ & -0.02 & -0.02 & -0.03 & -0.01 & -0.03 & -0.01 & 0.00 \\
\hline$(\mathrm{t}-1)$ & $-0.1 * * *$ & $-0.12 * * *$ & $-0.11 * * *$ & ${ }^{*}-0.13 * * *_{-}$ & $-0.11 * * *$ & $*-0.09 * *$ & $-0.1 * * *$ & $*_{-} 0.11 * * *$ \\
\hline GDP per Capita & $0.00 * * *$ & $0.00 * * *$ & $0.00 * * *$ & $0.00 * * *$ & $0.00 * * *$ & $* 0.00 * * *$ & $0.00 * * *$ & $* 0.00 * * *$ \\
\hline Centralised Collective Bargaining & & -0.07 & & -0.45 & & & & \\
\hline Labour Market Regulations & & & $-0.37 *$ & & & & & \\
\hline Taxes on Goods and Services & & & & $-0.12 * * *$ & $-0.11 * * *$ & $*_{-}-0.13 * * *$ & $-0.11 * * *$ & $*-0.12 * * *$ \\
\hline Taxes on Products & & & & $0.00 * *$ & $0.00 * * *$ & $* 0.00 * *$ & $0.00 * *$ & $0.00 * *$ \\
\hline Openness & & $0.03 * * *$ & $0.03 * * *$ & $0.05 * * *$ & $0.05 * * *$ & $* 0.05 * * *$ & $0.05 * * *$ & $* 0.06 * * *$ \\
\hline Credit Market Regulations & & & & -0.03 & & & & \\
\hline Banking Crisis & & & & $1.42 * *$ & $1.38 * *$ & 0.4 & $1.02 *$ & $1.3 * *$ \\
\hline SD M2 Growth (monthly) & & & & & & 0.13 & & \\
\hline SD Inflation (monthly) & & & & & $1.10 * *$ & & & $1.09 * *$ \\
\hline SD ER Growth (monthly) & & & & & & & $0.26 * *$ & 0.24 \\
\hline Constant & $13 * * *$ & $11 * * *$ & $12.5 * * *$ & * $22.2 * * *$ & $17 * * *$ & * $18.3 * * *$ & $15.6 * * *$ & * $14.6 * * *$ \\
\hline $\mathbf{N}$ & 711 & 544 & 582 & 352 & 338 & 300 & 357 & 310 \\
\hline Groups & 72 & 62 & 66 & 46 & 47 & 43 & 49 & 43 \\
\hline $\mathbf{F}$ & 6.1 & 5.31 & 5.58 & 4.77 & 5.48 & 4.45 & 5.28 & 4.92 \\
\hline $\mathbf{R}^{2}$ & 0.16 & 0.2 & 0.19 & 0.31 & 0.33 & 0.31 & 0.31 & 0.34 \\
\hline
\end{tabular}


The panel data estimations in the basic setting include the following variables: CBT and squared CBT, CBI, inflation ${ }^{20}$, terms of trade, real interest rate, GDP growth, lagged GDP growth, and GDP per capita. The variables of main interest are central bank transparency and independence. In most estimations, there is evidence for the theoretical conclusion that central bank independence leads to higher unemployment rates. Central bank independence can be interpreted as a proxy for central bank conservativeness as more autonomous central banks usually care less about business cycles but focus more on price stability. On the other hand, there were contradictory results in the theoretical literature regarding the effect of central bank transparency. The panel estimations clearly show that transparency does not lead to higher unemployment. In fact, there is some evidence that central bank transparency can reduce the negative effect of independence. Thereby, the relation between central bank transparency and unemployment rates seems, in most estimations, to be non-linear. Accordingly, central bank transparency can reduce unemployment rates but only up to a certain value.

Apart from that, the estimations also confirm most of the theories regarding the control variables. The variables capturing business cycle effects - inflation and GDP growth - are in most estimations negatively related to unemployment rates. This confirms that short-term effects induced by aggregated demand that result in GDP growth and inflation lead to lower unemployment. We see that lagged GDP growth is much more relevant than current GDP growth. This is reasonable given the fact that labour markets do not immediately react to business cycle changes but only with some delay. An economic explanation for this phenomenon is that in most countries there is some degree of employment protection. Therefore, employers can lay off workers only after some time. Real interest rates are not of great importance. In some estimations, real interest rates are significantly positively correlated with unemployment. However, sometimes the variable has the wrong sign showing that higher real interest rates lead to lower unemployment. Surprisingly, trade openness is, on the whole, positively related to unemployment. Iversen (1998a), too, finds that openness and unemployment are positively correlated when using annual data. The robustness checks in the Appendix show that the freedom to trade internationally (fe16/re16 and fe22/re22) leads to lower unemployment rates. This confirms the main result by Felbermayr, Prat, and Schmerer (2011) that trade might be beneficial for employment.

In order to confirm the result that central bank transparency is not harmful in terms of higher unemployment rates, we do a multitude of robustness checks. The main strategy is to test for effects of other explanatory variables that have been found to be relevant for unemployment (section 3.1 to 3.8). We argued before that centralisation of wage bargaining might be relevant. We include several variables to cover this effect (see estimations fe4 to fe10 in Table A.3): centralised collective bargaining, right of association (market sector), uncoordinated bargaining, state imposed/ sponsored bargaining, and two measures for union density. The results show that collective wage bargaining might in fact help to reduce unemployment rates although not all variables are significantly different from zero. On the other hand, union density is related to higher unemployment rates. Following the theoretical considerations above, it might be reasonable to test whether interaction terms play a role. The interaction term between

\footnotetext{
${ }^{20}$ There might be concern that inflation and unemployment are determined simultaneously which might blur the results presented in Table 3. However, the results are virtually the same when we exclude inflation.
} 
central bank independence and union density is positive. That means that the adverse effect of central bank independence on employment is higher in countries where union density is higher. On the other hand, the interaction between transparency and union density shows that the nonlinear relation between transparency and unemployment is stronger in countries with higher union density. This is a plausible result: central bank communication might be especially helpful in countries where unions have more to say as unions then can incorporate central bank information in the wage bargaining process. In an alternative system with individual wage bargaining (perfect competition), each worker has a low bargaining power and wages will be equal to the perfect competition equilibrium wage. In such a scenario, information about future monetary policy is less relevant for workers as they know that their wage decision has no impact on the monetary policy by the central bank.

Furthermore, we control for several labour market variables. Among these are advance notice, the Fraser Institute's labour market regulation index. Surprisingly, the labour market regulation index does not play a role. Other government regulations do not seem to matter much. Neither government effectiveness nor credit market or business regulation are of major relevance.

Furthermore, we control for tax effects by including taxes on goods and services and taxes on products. Net taxes on products are positively related to unemployment while taxes on goods and services are surprisingly negatively correlated with unemployment rates.

As an additional variable we include a dummy variable indicating whether a country was in a banking crisis. Our data sources are Caprio et al. (2005), Demirgüç-Kunt and Detragiache (2005), and Laeven and Valencia (2012). The coefficient of the dummy variable is positive and significantly different from zero in most estimations. This tells us that banking crises have an extra effect on unemployment in addition to its effect on GDP growth. However, the diminishing effect of central bank transparency on unemployment still exists in most estimations when we include other determinants of unemployment. This puts more trust in our results.

Finally, we check the restricted data set (1998 - 2005) which allows us to use the data of Aleksynska and Schindler (2011). The results of these estimations are available as a robustness check in the Appendix in Table A.4. The main result in these estimations is that central bank transparency does not lead to higher unemployment rates but, in most estimations, has rather no effect on unemployment. This can most likely be explained by the fact that the number of observations is much lower in the restricted data set. However, there is no evidence whatsoever for the hypothesis that transparency raises unemployment - also in the restricted data set.

The focus of this paper lies in the question of what effect central bank transparency and independence have on unemployment. When looking at the estimation results, we see that in most cases central transparency is non-linearly related to unemployment while central bank independence increases unemployment rates. The average effect is in most cases unemployment reducing. The turning point (i.e. $\left|\frac{\widehat{\beta}_{1}}{2 \cdot \widehat{\beta}_{2}}\right|$ ) in the estimated models lies between 6.5 and 8.5 in most estimations. This is clearly higher than the mean of CBT which is 4.7. In fact, 6.5 is the value of the 75 percentile of the observed values of CBT, where 8.0 would be the value of the 80 percentile of the respective variable. Thus, for the vast majority of cases we find that an increase in transparency results in a decrease in unemployment. 
Still the question is where this effect comes from. In estimation fe6 in Table 2, we include the standard deviation of M2 growth to control for fluctuations in money growth. It might be the case that more transparent central banks simply conduct more consistent and less volatile monetary policy. As it turns out central bank transparency still has a negative effect on employment when we control for volatility of money growth. Then we include the standard deviation of inflation because the study by Feldmann (2012) argues that inflation volatility increases unemployment. If we include this variable, central bank transparency is still significant (model fe5). Then we add the standard deviation of exchange rate growth (fe7). Exchange rate volatility, too, leads to higher unemployment. This is another channel through which central bank transparency might affect unemployment. Interestingly enough, central bank transparency and independence are again significant determinants of unemployment when we include both the standard deviations of inflation and exchange rate growth rates (models fe8). This is an intriguing result. It seems that central bank transparency can reduce the adverse effect of central bank independence. In order to test this presumption we replicate the regressions by including an interaction between $\mathrm{CBI}, \mathrm{CBT}$, and $\mathrm{CBT}^{2}{ }^{21}{ }^{21}$ The results confirm the idea that central bank transparency helps to reduce the detrimental effect of central bank independence. What we find is that if central bank transparency reduces unemployment rates, then this effect is contingent on the level of central bank independence. At the same time, the coefficients of CBI are much higher in these estimations. However, in some of the estimations CBT turns out not to be significantly different from zero. This can most probably be attributed to the fact that significance gets lost if $\mathrm{CBT}$ and $\mathrm{CBT}^{2}$ are included both as plain values and as interacted variables with CBI.

As we mentioned before in section 4.1, the Eijffinger-Geraats-Index (Eijffinger and Geraats, 2006) has five dimensions: political transparency, economic transparency, policy transparency, operational transparency, and procedural transparency. It is instructive to estimate the effect of each of those categories on unemployment to see where the overall effect comes from. Each of these sub-indexes can have values from zero to three. The standard deviation of each sub-index varies from 0.70 to 0.84 . Table 3 shows the results of fixed effects estimations where in each case one of the five sub-indexes is included. ${ }^{22}$ As it turns out, it is the first (political), second (economic), third (policy), and fifth (procedural) sub-index that matter most. Operational transparency (CBT_4) is of no relevance. This result is not due to lower variation over time in this sub-index as the standard deviation of this sub-index is even higher than that of CBT_1, CBT_3, and CBT_5. However, the stunning result is that political transparency, operational transparency, and procedural transparency lead to lower unemployment while economic transparency is related to higher unemployment rates. The result is also intriguing from a different angle. According to sections 2.1.1 and 2.1.2, most theoretical models that argued against central bank transparency only referred to the publication of preferences of the central bank. This is captured by the first sub-index (political transparency). The sub-index contains three questions: Are the primary goals of the central bank explicitly mentioned (including a clear order when a central bank has multiple goals)? Does the central bank quantify its goals? Does the central bank have full instrument independence? Thus, this sub-index essentially

\footnotetext{
${ }^{21}$ The results of these estimations are available upon request.

${ }^{22}$ In the case of the sub-indices, there is no evidence for a non-linear relationship.
} 
covers the central bank's reaction function and its decision-making independence. As it turns out this sub-index is negatively related to unemployment rates. This is the opposite of what authors like Sørensen (1991) and Grüner (2002) have proclaimed in their theoretical models and confirms the theoretical considerations of the present article whereby under certain circumstances, higher political transparency leads to lower unemployment rates.

\section{Table 3: Effect of Sub-Indexes of Central Bank Transparency}

\begin{tabular}{|c|c|c|c|c|c|c|c|c|c|c|}
\hline Variable & sub1 & & sub2 & & sub3 & & sub4 & & sub5 & \\
\hline Inflation & -0.0001 & & 0.0029 & & -0.0012 & & 0.0021 & & 0.0035 & \\
\hline Terms of Trade & 0.0023 & & 0.0038 & & 0.0010 & & 0.0014 & & 0.0042 & \\
\hline Real interest rate & -0.0090 & & -0.0064 & & -0.0074 & & -0.0070 & & -0.0063 & \\
\hline GDP growth & 0.0334 & & 0.0404 & $*$ & 0.0357 & & 0.0338 & & 0.0302 & \\
\hline$(\mathrm{t}-1)$ & -0.1159 & $* * *$ & -0.1158 & $* * *$ & -0.1190 & $* * *$ & -0.1203 & $* * *$ & -0.1231 & $* * *$ \\
\hline GDP per capita & -0.0003 & $* * *$ & -0.0003 & $* * *$ & -0.0003 & $* * *$ & -0.0002 & $* * *$ & -0.0003 & $* * *$ \\
\hline CBT_1 (t-1) & -0.9817 & $* * *$ & & & & & & & & \\
\hline CBT_2 (t-1) & & & 0.6540 & $* *$ & & & & & & \\
\hline CBT_3 (t-1) & & & & & -0.7445 & $* *$ & & & & \\
\hline CBT_4 (t-1) & & & & & & & -0.3226 & & & \\
\hline CBT_5 (t-1) & & & & & & & & & -1.1649 & $* * *$ \\
\hline CBI & 4.2604 & $* *$ & 3.0823 & & 3.0781 & & 3.1136 & & 3.3024 & $*$ \\
\hline Constant & 11.7817 & $* * *$ & 9.8524 & $* * *$ & 11.0725 & $* * *$ & 10.4499 & $* * *$ & 11.2268 & $* * *$ \\
\hline $\mathbf{N}$ & 625 & & 625 & & 625 & & 625 & & 625 & \\
\hline Groups & 62 & & 62 & & 62 & & 62 & & 62 & \\
\hline $\mathbf{F}$ & 5.834 & & 5.635 & & 5.647 & & 5.453 & & 6.225 & \\
\hline $\mathbf{R}^{2}$ & 0.162 & & 0.157 & & 0.157 & & 0.153 & & 0.171 & \\
\hline AIC & 2624.7 & & 2628.1 & & 2627.9 & & 2631.3 & & 2618.0 & \\
\hline BIC & 2709.0 & & 2712.4 & & 2712.2 & & 2715.6 & & 2702.3 & \\
\hline Country FE & Yes & & Yes & & Yes & & Yes & & Yes & \\
\hline Time FE & Yes & & Yes & & Yes & & Yes & & Yes & \\
\hline
\end{tabular}

One might argue that the effect of transparency comes through wrong inflation expectations by individuals. Following the Philipps curve with rational expectations, an increase in inflation should only lead to a decrease in unemployment if the surge in prices was not anticipated. That means that only surprise inflation should move unemployment rates. Thus, we also analyse this hypothesis. As it turns out, central bank transparency tends to increase surprise inflation (actual inflation minus expected inflation). However, separate estimations show that surprise inflation neither affects wages nor unemployment. Therefore, there is no evidence that this is the mechanism through which central bank transparency influences wages and unemployment. ${ }^{23}$

Up to this point, we have only used static models. However, there might be persistence in unemployment rates. As argued above, we apply GMM to estimate a dynamic panel model with fixed effects. Here we use difference GMM where the lagged unemployment rate and (squared) central bank transparency are treated as endogenous variables. We instrument those variables with their lagged values. The results of these estimations are shown in Table 4.

\footnotetext{
${ }^{23}$ These estimation results are available upon request.
} 
Table 4: Dynamic Panel Data Estimations

\begin{tabular}{|c|c|c|c|c|c|c|c|c|c|c|c|c|c|}
\hline Variable & ab1 & ab2 & ab3 & ab4 & ab5 & ab6 & ab7 & ab8 & ab9 & ab10 & ab11 & ab12 & ab13 \\
\hline Unemployment (t-1) & $0.7456 * * *$ & $0.5787 * * *$ & $0.8018 * * *$ & $0.7965 * * *$ & $0.7889 * * *$ & $0.8898 * * *$ & $0.6457 * * *$ & $0.6056^{* * *}$ & $0.7848 * * *$ & $0.8430 * * *$ & * $0.7917 * * *$ & $0.5514 * * *$ & $0.6470 * * *$ \\
\hline CBT & & & & & & & & & $-1.2377 * *$ & $-1.2489 * *$ & $-1.3231 * *$ & $-1.4191^{*}$ & $-1.3579 * *$ \\
\hline $\mathrm{CBT}^{2}$ & & & & & & & & & $0.0575^{*}$ & $0.0554 *$ & 0.0388 & $0.0735^{*}$ & $0.0766^{* *}$ \\
\hline CBI & & & & & & & & & -4.5696 & -4.9052 & -5.8565 & 18.8679 & 2.8265 \\
\hline CBT $(t-1)$ & $-1.8110 * * *$ & $k-1.7818 * *$ & -1.0058 & -0.8688 & $-1.5836^{* *}$ & -0.9765 & $-1.8060 * * *$ & $k-1.8110 * * *$ & & & & & \\
\hline $\mathrm{CBT}^{2}(\mathrm{t}-1)$ & $0.0640 *$ & $0.0980 * *$ & 0.0364 & 0.0061 & 0.0579 & 0.0084 & $0.0611^{*}$ & $0.0899 * *$ & & & & & \\
\hline CBI (t-1) & -11.5562 & $16.5077^{*}$ & -5.1489 & -6.1052 & -3.8616 & -9.8535 & -7.4122 & 2.0416 & & & & & \\
\hline Inflation & -0.0079 & -0.0109 & -0.0462 & -0.0408 & -0.0424 & -0.0229 & -0.0143 & $-0.1077 *$ & -0.0073 & -0.0078 & -0.0093 & -0.0115 & $-0.0214 *$ \\
\hline Terms of trade & -0.0023 & -0.0020 & 0.0016 & -0.0011 & 0.0011 & 0.0025 & -0.0013 & 0.0131 & 0.0035 & 0.0041 & 0.0037 & -0.0018 & 0.0081 \\
\hline Real interest rate & -0.0107 & 0.0063 & -0.0078 & -0.0117 & -0.0118 & 0.0005 & $-0.0157 *$ & 0.0069 & -0.0022 & 0.0002 & 0.0024 & 0.0097 & -0.0079 \\
\hline GDP growth & $-0.0784 * *$ & -0.0627 & $-0.1090 * *$ & $-0.1058 * *$ & $-0.1155^{* *}$ & $-0.1366 * *$ & $-0.0842 * *$ & -0.0825 & -0.0573 & $-0.1014 * *$ & $-0.1174 * *$ & -0.0673 & -0.0677 \\
\hline$(\mathrm{t}-1)$ & $-0.0842 * * *$ & $-0.0755^{*} * *$ & $-0.0703 *$ & $-0.0654 * *$ & $-0.0637 * *$ & $-0.0658 * *$ & $-0.0914 * * *$ & ${ }^{k}-0.0527$ & $-0.0985^{* * *}$ & $-0.0680 * *$ & $-0.0737 * *$ & $-0.0906 * * *$ & $k_{-0} 0.1068 * * *$ \\
\hline GDP per capita & $-0.0003^{*}$ & $-0.0005 * *$ & -0.0002 & -0.0002 & -0.0001 & $-0.0001-$ & $-0.0003^{*}$ & $-0.0008 * *$ & $-0.0003 * *$ & $-0.0003 * *$ & $-0.0003 * *$ & $-0.0005 * * *$ & $-0.0003 * *$ \\
\hline Taxes on goods and services & & -0.1772 & & & & & & -0.0377 & & & & -0.2006 & \\
\hline Openness & & & 0.0263 & 0.0209 & 0.0324 & 0.0193 & 0.0534 & $0.0721 * *$ & & & & & $0.0763 * * *$ \\
\hline Legal system \& property rights & & & -0.5887 & & & & & & & & & & \\
\hline Freedom to trade internationally & & & & -1.3522 & & & & & & & & & \\
\hline Credit market regulations & & & & & 0.4646 & & & & & & & & \\
\hline Centralised collective bargaining & & & & & & -0.1030 & & & & & & & \\
\hline Right of association (market sector) & & & & & & & 8.1146 & & & & & & \\
\hline Banking Crisis & & & & & & & & 0.9559 & & & & & \\
\hline SD ER growth (monthly) & & & & & & & & 0.3394 & & & 0.0303 & & \\
\hline SD Inflation (monthly) & & & & & & & & & & -0.0060 & -0.0009 & & \\
\hline $\mathbf{N}$ & 726 & 518 & 609 & 608 & 609 & 537 & 719 & 343 & 689 & 603 & 528 & 481 & 683 \\
\hline Groups & 72 & 66 & 65 & 65 & 65 & 61 & 72 & 49 & 71 & 63 & 55 & 64 & 71 \\
\hline Hansen statistics & 42.926 & 39.794 & 40.355 & 39.512 & 41.216 & 42.406 & 38.267 & 29.095 & 50.068 & 43.138 & 37.379 & 42.184 & 44.795 \\
\hline p-value & 0.389 & 0.479 & 0.367 & 0.402 & 0.332 & 0.287 & 0.503 & 0.820 & 0.157 & 0.380 & 0.632 & 0.377 & 0.278 \\
\hline $\mathbf{A R}(\mathbf{1})$ & -2.137 & -1.719 & -2.022 & -2.024 & -2.039 & -1.676 & -1.940 & -1.700 & -2.091 & -2.188 & -2.163 & -1.654 & -1.987 \\
\hline p-value & 0.033 & 0.086 & 0.043 & 0.043 & 0.041 & 0.094 & 0.052 & 0.089 & 0.037 & 0.029 & 0.031 & 0.098 & 0.047 \\
\hline $\mathbf{A R}(2)$ & -0.566 & -2.138 & -0.529 & -0.892 & -0.574 & -0.664 & -0.535 & -0.040 & -0.009 & 0.512 & 0.454 & -1.151 & -0.066 \\
\hline p-value & 0.572 & 0.032 & 0.597 & 0.373 & 0.566 & 0.506 & 0.593 & 0.968 & 0.993 & 0.609 & 0.650 & 0.250 & 0.947 \\
\hline
\end{tabular}

Notes: The table shows the results of difference GMM estimations with robust standard errors where the dependent variable is the unemployment rate. Lagged unemployment, TI, and TI ${ }^{2}$ are treated as endogenous variables. The instruments being used are the lagged endogenous variables plus the lagged nominal interest rate and the lagged population growth. The asterisks indicate whether a coefficient is significantly different from zero at the $10 \%$ (one asterisk), $5 \%$ (two asterisks) or $1 \%$ (three asterisks) significance level. 
Table 5: Simultaneous Equation Estimations

\begin{tabular}{|c|c|c|c|c|c|c|c|c|c|c|c|c|}
\hline Variable & tsls1 & tsls2 & tsls3 & tsls4 & tsls5 & tsls6 & tsls7 & tsls8 & tsls9 & tsls10 & tsls11 & tsls12 \\
\hline \multicolumn{13}{|l|}{ First Stage: } \\
\hline$\overline{\text { Dep. Var. }}$ & hw2wuus & hw3wuus & hw4wuus & hw2wlus I & hw3wlus & hw4wlus & mw2wuus n & mw3wuus & mw4wuus & mw2wlus & mw3wlus & mw4wlus \\
\hline CBT & $-0.9607 * *$ & $-0.4639^{*}$ & $-0.5263 * *$ & $-0.9261 * *$ & $-0.4473^{*}$ & $-0.5134^{*}$ & $-196.1398 * *$ & $-74.2899 * *$ & $-76.8792 *$ & $-189.1191 * *$ & $-70.5153^{*}$ & $-75.4723 *$ \\
\hline $\mathrm{CBT}^{2}$ & $0.0829 * * *$ & $0.0375^{* *}$ & $0.0480 * * *$ & * $0.0806^{* * *}$ & $0.0361 * *$ & $0.0475 * *$ & $16.1544 * * *$ & $6.5213^{* *}$ & $7.3375^{* *}$ & $15.7038 * * *$ & $6.1925^{* *}$ & $7.3986^{* *}$ \\
\hline CBI & $2.4177 *$ & 2.0587 & $3.9053 * *$ & 2.3341 & 2.0114 & $3.9027 * *$ & 355.4376 & $397.1639 *$ & $749.0665 * * *$ & * 346.4061 & $399.9733^{*}$ & $732.2617 * * *$ \\
\hline \multicolumn{13}{|l|}{ Second Stage: } \\
\hline $\begin{array}{l}\text { Dep. Var. } \\
\text { Inflation }\end{array}$ & Unemp. & Unemp. & Unemp. & Unemp. & Unemp. & Unemp. & Unemp. & Unemp. & Unemp. & Unemp. & Unemp. & Unemp. \\
\hline Terms of Trade & $-0.0225^{* *}$ & $-0.0247 * *$ & $-0.0243 * * *$ & $*-0.0226 * *$ & $-0.0252 * *$ & $-0.0244 * * *$ & $-0.0238 * *$ & $-0.0223^{* * *} *$ & $-0.0231 * * *$ & $-0.0237 * *$ & $-0.0227 * * *$ & $-0.0232 * * *$ \\
\hline Real Interest Rate & -0.0374 & -0.0225 & -0.0218 & -0.0378 & -0.0231 & -0.0220 & -0.0344 & -0.0209 & -0.0201 & -0.0342 & -0.0211 & -0.0206 \\
\hline GDP Growth & -0.0313 & -0.0075 & -0.0242 & -0.0313 & -0.0052 & -0.0249 & -0.0147 & -0.0182 & -0.0289 & -0.0143 & -0.0157 & -0.0310 \\
\hline$(\mathrm{t}-1)$ & $-0.1259 * * *$ & $-0.0896 * *$ & $-0.0987 * * *$ & $*-0.1269 * * *$ & $-0.0889 * *$ & $-0.0998 * * *$ & $-0.1406 * * *$ & $-0.0979 * * *$ & $-0.1025^{* * *}$ & $-0.1418 * * *$ & $-0.0972 * * *$ & $-0.1040 * * *$ \\
\hline $\begin{array}{l}\text { GDP per Capita } \\
\text { hw } 2 \text { wuus }\end{array}$ & $\begin{array}{c}-0.0004 \\
0.5333 *\end{array}$ & -0.0005 & $-0.0004 *$ & -0.0004 & -0.0005 & $-0.0004 *$ & -0.0003 & -0.0005 & $-0.0004 *$ & -0.0004 & $-0.0005^{*}$ & $-0.0004 *$ \\
\hline & $0.5333^{*}$ & 0.6258 & & & & & & & & & & \\
\hline hw4wuus & & & $0.4511 *$ & & & & & & & & & \\
\hline hw2wlus & & & & $0.5398 *$ & & & & & & & & \\
\hline hw3wlus & & & & & 0.6535 & & & & & & & \\
\hline hw4wlus & & & & & & $0.4489 *$ & & & & & & \\
\hline mw2wuus & & & & & & & $0.0035 * *$ & & & & & \\
\hline mw3wuus & & & & & & & & $0.0034^{*}$ & & & & \\
\hline mw4wuus & & & & & & & & & $0.0027 * *$ & & & \\
\hline mw2wlus & & & & & & & & & & $0.0036 * *$ & & \\
\hline mw3wlus & & & & & & & & & & & $0.0036^{*}$ & \\
\hline mw4wlus & & & & & & & & & & & & $0.0026^{* *}$ \\
\hline Constant & $14.0322 * * *$ & $15.0480 * * *$ & $14.1208 * * *$ & * $14.2843 * * *$ & $=15.4585 * * *$ & * $14.2189 * * *$ & $13.6295 * * *$ & $14.5449 * * *$ & $14.6134 * * *$ & $14.1870 * * *$ & 15.1583 **** & $14.4511 * * *$ \\
\hline $\mathbf{N}$ & 164 & 246 & 246 & 164 & 246 & 246 & 139 & 246 & 246 & 139 & 246 & 246 \\
\hline Groups & 30 & 41 & 41 & 30 & 41 & 41 & 28 & 41 & 41 & 28 & 41 & 41 \\
\hline $\mathbf{R}^{2}$ & 0.27 & 0.21 & 0.22 & 0.27 & 0.21 & 0.22 & 0.31 & 0.20 & 0.21 & 0.33 & 0.20 & 0.21 \\
\hline $\mathrm{Chi}^{2}$ & $3651.78 * * *$ & $7369.10 * * *$ & $=8011.18 * * *$ & * $3657.63 * * *$ & $7202.40 * * *$ & * $8063.22 * * *$ & $3255.91 * * *$ & $8213.92 * * *$ & $8406.36 * * *$ & $3248.53 * * *$ & $8028.13^{* * *}$ & $8511.57 * * *$ \\
\hline
\end{tabular}

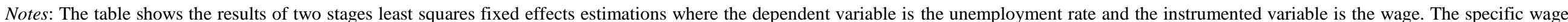

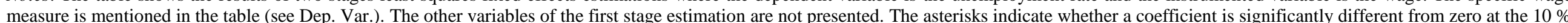
(one asterisk), $5 \%$ (two asterisks) or $1 \%$ (three asterisks) significance level. 
Table 4 confirms persistence in unemployment rates. The coefficient on the lagged unemployment rate is positive and statistically significant in most estimations. Again we control for several other potential determinants of unemployment. The results are somewhat different from the one in Table 3. However, the main conclusion regarding the effect of central bank transparency is still the same. In most estimations, we find a non-linear relationship between central bank transparency and unemployment even when allowing for persistence in unemployment rates. The turning point (i.e. $\left|\frac{\widehat{\beta}_{1}}{2 \cdot \widehat{\beta}_{2}}\right|$ ) in the estimated models has a value of at least 6.6 where the average value of the turning point is well above 10. Again, this is higher than the mean of CBT (4.7). Central bank transparency seems to have a dampening effect on unemployment. On the other hand, central bank independence is hardly relevant in the dynamic version. GDP growth and inflation are still highly relevant as variables capturing business cycle effects. GDP per capita works as a variable representing the overall development of countries. According to the estimations, more developed countries tend to have lower unemployment rates.

Once again we include measures for inflation and exchange rate volatility. However, central bank transparency is still significant when we include those two variables. This confirms the previous result that the effect of central bank transparency might be partly transmitted through lower exchange rate and inflation volatility. However, there seems to be an additional effect of central bank transparency.

The estimations also show the results of the Arellano and Bond (1991) test for serial correlation in first differences of the error term. $\mathrm{AR}(2)$ serial correlation especially would be problematic. However, there is neither evidence for an $\mathrm{AR}(1)$ process nor an $\mathrm{AR}(2)$ process in first differences of the error term as the null hypothesis of no serial correlation is never rejected. Furthermore, we can test the exogeneity of the instrumental variables with Hansen's j-statistic for overidentifying restrictions. The null hypothesis of this test is that the instruments are exogenous. There is not a single case where this null hypothesis is rejected. This allows us to put some trust in the results.

Therefore, the second interim result is that there is no evidence that central bank transparency raises unemployment. In contrast to the theoretical considerations, central bank transparency diminishes unemployment rates according to the majority of the estimations. This result questions the current theoretical models.

\subsection{The Link between Wages and Unemployment}

Hitherto, we have analysed the two main hypothesis discussed in the theoretical literature that said that CBT causes higher wages and higher unemployment. The empirical estimations have shown that these hypotheses are suspect as there is not much evidence for these considerations. Now we want to estimate one of the mechanisms through which CBT affects unemployment. The idea is that transparency influences wages which leads to an effect on unemployment. As we argued in section 4.2, this calls for simultaneous equation models. However, an actual simultaneous equation of wages and unemployment would be problematic as unemployment could have feedback effects on wages. An increase in unemployment might lead workers to diminish their reservation wages. If this is the case, there could be a problem of reverse causality 
when estimating the effect of wages on unemployment. We try to circumvent this problem by only including wages as lagged variables. The unemployment rate of the current year should not have a direct effect on the wages of the previous period. Consequently, we assume that CBT and CBI of the previous period are the relevant determinants of the wages of the previous period. This fits with the estimations presented in section 5.2 where CBI and CBT were also included as lagged explanatory variables. The method for the simultaneous equations is two stages least squares. The main results of these estimations are presented in Table 5. Further estimations are presented in the Appendix (Table A.5)

The upper part of Table 5 shows the main variables of interest of the first stage that serve as instrumental variables. The other explanatory variables of the first stage are not shown for the sake of brevity. The lower part of the table shows the estimation results of the second stage. The estimations of the first stage confirm the result of section 5.1. CBT seems to reduce average wages with the effect, in most occasions, being non-linear. On the other hand, CBI is related to higher wages in some estimations. The fitted values for the wage rate are then used together with some other explanatory variables when analysing the determinants of unemployment on the second stage of the estimations. The results are mixed as in some estimations the wage rate does not have a significant impact on unemployment. This might be due to the fact that standard errors usually increase when using two stages least squares. However, in most estimations we find that wages are related to higher unemployment rates. This supports the idea that CBT affects unemployment through wages. While there is evidence for a diminishing effect of CBT on wages according to the first stage regressions, the wage rates themselves affect unemployment rates following most of the second stage estimations. This rounds off the story presented in the previous two sections. To sum up, there is no evidence for a detrimental effect of CBT on employment. Quite the contrary: there is some evidence that CBT can actually help to reduce the negative effect of CBI. This is an intriguing result as it challenges most of the theoretical literature. While many of the theoretical arguments might still be true the main problem of the studies was that they did not distinguish between transparency and independence or conservativeness. Future theoretical research might incorporate central bank independence in the analysis of effects of CBT on unemployment. This might lead to models that are more in line with the empirical evidence.

\subsection{Transparency and Unemployment Volatility}

The final step is to analyse the effect of central bank transparency on unemployment volatility. Again the empirical approach is a fixed effects panel data estimation. The dependent variable is in all cases the standard deviation of the quarterly unemployment within a given year. We discussed the possible determinants of unemployment volatility in section 3.9. Apart from those factors, we control for the annual unemployment rate as we expect - as in the case of inflation volatility - that higher unemployment rates are also related to higher fluctuations of the unemployment rate. The results of the estimations are presented in Table 6. Table A.6 in the Appendix shows the robustness checks including further explanatory variables. 
Table 6: Causes of Unemployment Variability

\begin{tabular}{|c|c|c|c|c|c|c|c|c|c|c|c|c|c|c|c|c|}
\hline Variable & fe1 & $\mathrm{fe} 2$ & fe3 & fe4 & fe5 & fe6 & fe7 & fe8 & fe9 & fe10 & fe11 & fe12 & fe13 & fe14 & fe15 & fe16 \\
\hline Unemployment & $0.0285^{* * * *}$ & $0.0508^{* * *}$ & * 0.0035 & $0.0254^{* * * *}$ & $0.0255^{* * *}$ & $0.0394 * * *$ & $0.0387^{* * * *}$ & $0.0382 * * *$ & $0.0373^{* * * *}$ & $0.0299 * *$ & $0.0399 * * *$ & $0.0382 * * *$ & 0.0090 & $0.0298 * *$ & $0.0270^{* * *}$ & $0.0385^{* * * *}$ \\
\hline CBT (t-1) & -0.0075 & $-0.0382^{*}$ & -0.0284 & -0.0112 & -0.0132 & -0.0307 & $-0.0398 * *$ & $-0.0397 * *$ & $-0.0425 * *$ & $-0.0570 * *$ & $-0.0410 * *$ & $-0.0400 *$ & $-0.0328^{*}$ & -0.0311 & -0.0327 & $-0.0355^{*}$ \\
\hline CBI (t-1) & 0.2743 & $0.4920^{*}$ & $0.5657^{*}$ & 0.2537 & 0.3308 & $0.7424 * * *$ & 0.7886 *** & $0.7928^{* * *}$ & $0.7635^{* * * *}$ & $0.6960 *$ & $0.6373^{* * * *}$ & $0.6442 * * *$ & * $0.3910 *$ & $0.6109 * *$ & $0.7356^{*}$ & 0.3012 \\
\hline Real Interest Rate & -0.0001 & 0.0032 & & 0.0004 & -0.0002 & 0.0031 & 0.0043 & 0.0046 & 0.0048 & 0.0108 & 0.0075 & 0.0083 & -0.0053 & -0.0069 & $0.0116^{*}$ & 0.0005 \\
\hline SD GDP Growth & & 0.0081 & & & & & & & & & & & & & & \\
\hline GDP growth & & & & 0.0000 & & & & & & & & & & & & \\
\hline Openness & & & & $0.0037 * * *$ & $0.0036 * *$ & $0.0031^{*}$ & $0.0036 * *$ & $0.0036^{* *}$ & $0.0040 * *$ & $0.0053^{*}$ & 0.0039 & $0.0041^{*}$ & 0.0007 & -0.0003 & 0.0001 & $0.0071 * * *$ \\
\hline Gross Replacement Rate (2 Year Average) & & & 0.4579 & & & & & & & & & & & & & \\
\hline Freedom to Trade & & & & & $0.0682 *$ & & & & & & & & & & & \\
\hline Right of Assocation (Market Sector) & & & & & & $0.2356^{*}$ & & & & & & & & & & \\
\hline Right to Strike (Market Sector) & & & & & & & 0.0217 & & & & & & & & & \\
\hline Right of Collective Bargaining (Market Sector) & & & & & & & & -0.0357 & & & & & & & & \\
\hline Right of Collective Bargaining Government Sector & & & & & & & & & $-0.1543 *$ & & & & & & & \\
\hline Social Pact (Employment Policies) & & & & & & & & & & -0.0421 & & & & & & \\
\hline Coordination & & & & & & & & & & & & & & & 0.0791 & \\
\hline Union Density & & & & & & & & & & & -0.0048 & 0.0012 & & & & \\
\hline Union Density² & & & & & & & & & & & & -0.0001 & & & & \\
\hline Union Density (2) & & & & & & & & & & & & & & 0.0033 & & \\
\hline Union Density ${ }^{2}(2)$ & & & & & & & & & & & & & & 0.0000 & & \\
\hline Civil Liberties & & & & & & & & & & & & & -0.0588 & & & \\
\hline Left-Winged & & & & & & & & & & & & & & & & $-0.1054 * *$ \\
\hline Constant & $0.2880 * *$ & 0.1335 & $0.4985 * *$ & $*-0.1547$ & $-0.6167 *$ & $-0.7301 *$ & -0.1447 & -0.0034 & 0.1315 & -0.1275 & 0.1386 & 0.0178 & $0.6862 * * *$ & 0.3615 & -0.0223 & -0.0891 \\
\hline $\mathbf{N}$ & 486 & 305 & 219 & 481 & 446 & 309 & 309 & 309 & 309 & 217 & 197 & 197 & 363 & 257 & 238 & 338 \\
\hline Groups & 44 & 29 & 35 & 43 & 43 & 27 & 27 & 27 & 27 & 19 & 17 & 17 & 44 & 29 & 21 & 35 \\
\hline Adj. $\mathbf{R}^{2}$ & -0.070 & 0.015 & -0.194 & -0.051 & -0.074 & 0.033 & 0.020 & 0.020 & 0.033 & -0.018 & 0.102 & 0.098 & -0.110 & -0.063 & -0.041 & -0.016 \\
\hline $\mathbf{R}^{2}$ & 0.101 & 0.077 & 0.023 & 0.016 & 0.094 & 0.329 & 0.286 & 0.281 & 0.241 & 0.313 & 0.314 & 0.301 & 0.104 & 0.164 & 0.191 & 0.115 \\
\hline AIC & 183.223 & 108.570 & 41.961 & 177.467 & 177.434 & 91.782 & 95.985 & 95.887 & 91.567 & 78.097 & -22.800 & -21.086 & 53.448 & 43.031 & 91.587 & 76.885 \\
\hline BIC & 254.388 & 175.536 & 79.241 & 256.808 & 251.239 & 162.716 & 166.918 & 166.820 & 162.501 & 142.315 & 39.581 & 44.578 & 115.759 & 110.463 & 157.560 & 149.523 \\
\hline CBT_1 & -0.0164 & -0.0094 & -0.0567 & -0.0209 & -0.0769 & -0.0131 & -0.0218 & -0.0249 & -0.0331 & -0.1228 & $-0.1834^{*}$ & $-0.1834 *$ & 0.0053 & -0.0142 & -0.0387 & -0.0068 \\
\hline CBT_2 & 0.0051 & -0.0110 & -0.0689 & 0.0035 & -0.0021 & 0.0458 & 0.0124 & 0.0080 & -0.0001 & 0.0057 & 0.0034 & 0.0065 & -0.0375 & 0.0566 & 0.0618 & -0.0717 \\
\hline CBT_3 & $-0.1878^{* * * *}$ & -0.2041 *** & ${ }^{*}-0.1235^{*}$ & $-0.1949 * * *$ & $-0.2295 * * *$ & $-0.2041 * * *$ & $-0.2244 * * *$ & $-0.2254 * * *$ & $-0.2379 * * *$ & $-0.2664 * * *$ & k-0.1652* & $-0.1723^{*}$ & $-0.1916^{* * * *}$ & $*-0.1959 * * *$ & $*-0.1811 * *$ & $-0.2512 * * *$ \\
\hline CBT_4 & -0.0628 & $-0.1313^{* *}$ & $-0.0968^{*}$ & -0.0652 & -0.0732 & $-0.1375^{* * *}$ & $-0.1484 * * *$ & $-0.1499 * * *$ & $-0.1424 * * *$ & $-0.1383 * *$ & -0.0952 & -0.0959 & -0.0642 & $-0.1416^{* * *}$ & $*-0.1735^{* * *}$ & -0.0651 \\
\hline CBT_5 & $-0.1309 * *$ & $-0.2062 * *=$ & $*-0.1529 * *$ & $*-0.1163 * *$ & $-0.1327 * *$ & $-0.1464 * *$ & $-0.1496 * *$ & $-0.1451^{*}$ & -0.1191 & $-0.2426 * *$ & -0.1300 & -0.1341 & $-0.1763 * * *$ & $*-0.1094$ & -0.1424 & $-0.2254 * * *$ \\
\hline
\end{tabular}

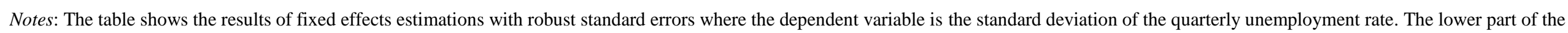

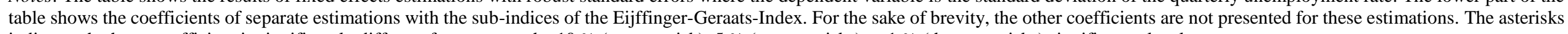
indicate whether a coefficient is significantly different from zero at the $10 \%$ (one asterisk), $5 \%$ (two asterisks) or $1 \%$ (three asterisks) significance level 
In the basic setting of the estimations, we include the unemployment rate, the real interest rate, and lagged central bank transparency and independence. In the simplest setting where we only control for these factors, only the unemployment rate is a significant determinant of unemployment fluctuations. However, the picture changes when we add further explanatory variables. Most importantly, in all estimations the coefficient of central bank transparency is negative whereas the coefficient of central bank independence is negative. In many of the estimations, the coefficients are significantly different from zero confirming that central bank independence leads to higher unemployment fluctuations - as postulated, for instance, by Rogoff (1985) - while central bank transparency reduces unemployment variability. This result holds even if control for the fact that central bank transparency might already have a diminishing effect on the unemployment rate itself. We continue by including further explanatory variables mentioned in the literature. This includes measures for labour market regulation, unemployment benefits, union density, and coordination of wage bargaining. Even in these estimations, central bank transparency does not lead to higher volatility of unemployment rates. Although the goodness of fit of the estimations is not overly high, the results are still meaningful as they show that there is no need for much concern that transparency comes at the cost of high unemployment volatility.

In addition, the table includes the results for separate estimations of the effects of the five dimensions of the Eijffinger-Geraats-Index on unemployment volatility. For the sake of brevity, the results for the control variables are not included. In most estimations, policy transparency (CBT_3), operational transparency (CBT_4), and procedural transparency (CBT_5) tend to diminish unemployment fluctuations. Policy transparency seems to matter most. This dimension includes the publishing of the policy rule or strategy, minutes, and voting records. It may help to predict future monetary policy decisions and, thus, stabilise the economy. On the other hand, political transparency (CBT_1) and economic transparency (CBT_2) are of lower importance. At least, we do not find much evidence for Muto's (2013) theoretical result that transparency in the central bank's forecast is only desirable if the public assumes that the central bank's estimate of permanent productivity growth is different from their own. The estimations show that economics transparency (publishing of basic economic data, macroeconomic models, and macroeconomic forecasts) does not lead to higher unemployment variability.

\section{Conclusions}

The main idea of this study was to analyse the effect of central bank transparency on unemployment. Initially, the article presented a simple game theoretic model and showed that opaqueness regarding the central bank's preferences are not necessarily beneficial in terms of lower unemployment. Then the article summarised other studies analysing the relation between transparency and unemployment theoretically. The theoretical models come to different results. The majority of these studies conclude that CBT is not desirable as it leads to higher unemployment rates through increased wages. Secondly, we looked at the role of central bank independence and centralisation of wage bargaining. Here most papers argue that central bank independence should be related to higher unemployment rates. Thirdly, we looked at empirical studies analysing the determinants of unemployment and unemployment volatility. There is 
evidence that shows that business cycle effects, labour market regulation, other government regulations, and several macroeconomic variables are relevant in determining unemployment rates. The role of central bank transparency has hardly been considered in the literature.

The estimation results showed that central bank transparency might actually be beneficial in terms of lower wages and unemployment rates. On the other hand, central bank independence seems to lead to higher wages and unemployment rates. The estimations also provided evidence for the hypothesis that the positive effect of central bank transparency comes partly by providing more stable inflation and exchange rates. The results were confirmed by dynamic panel data models where we still found a positive impact of lower opaqueness. Finally, simultaneous equation models delivered some empirical evidence for the hypothesis that the effect of CBT on unemployment goes through wages. Finally, the estimations reject the presumption that central bank transparency induces higher unemployment fluctuations. Thus, the main result in contrast to the majority of the theoretical literature is that the pessimistic view on central bank transparency might be unfounded as there is no evidence that transparency leads to higher unemployment (volatility).

The results are economically significant and relevant as they are in sharp contrast to the majority of theoretical models analysing the effects of central bank transparency. Therefore, this study might help to change the negative view that many economists have on central bank transparency. It should also encourage further theoretical research that takes into account the effects of both central bank transparency and independence as well as other channels of transmission of central bank transparency. 


\section{References}

Abbritti, M., \& Weber, S. (2010). Labor market institutions and the business cycle Unemployment rigidities vs. real wage rigidities (No. 1183). ECB Working Paper.

Agell, J. (1999). On the benefits from rigid labour markets: norms, market failures, and social insurance. The Economic Journal, 109(453), 143-164.

Aleksynska, M., \& Schindler, M. (2011). Labor market institutions in advanced and developing countries: a new panel database. IMF Working Papers, (11/154).

Alesina, A., \& Summers, L. H. (1993). Central bank independence and macroeconomic performance: some comparative evidence. Journal of Money, Credit and Banking, 25(2), 151-162.

Arellano, M., \& Bond, S. (1991). Some tests of specification for panel data: Monte Carlo evidence and an application to employment equations. The Review of Economic Studies, 58(2), 277-297.

Baccaro, L., \& Rei, D. (2007). Institutional determinants of unemployment in OECD countries: Does the deregulatory view hold water?. International Organization, 61(3), 527-569.

Baker, D., Glyn, A., Howell, D., \& Schmitt, J. (2005). Labour market institutions and unemployment. Fighting Unemployment: Limits of Free Market Orthodoxy.

Ball, L. (1999). Aggregate demand and Long-Run Unemployment. Brookings Papers on Economic Activity, 30(2), 189-236.

Ball, L., De Roux, N., \& Hofstetter, M. (2013). Unemployment in Latin America and the Caribbean. Open Economies Review, 24(3), 397-424.

Barro, R. J., \& Gordon, D. B. (1983). A Positive Theory of Monetary Policy in a Natural Rate Model. The Journal of Political Economy, 91(4), 589-610.

Bassanini, A., \& Duval, R. (2006). The determinants of unemployment across OECD countries: Reassessing the role of policies and institutions. OECD Economic Studies, 42(1), 7-86.

Bean, C. R. (1994). European unemployment: A retrospective. European Economic Review, $38(3), 523-534$.

Belke, A., \& Gros, D. (2002a). Designing EU-US Atlantic monetary relations: exchange rate variability and labour markets. The World Economy, 25(6), 789-813.

Belke, A., \& Gros, D. (2002b). Monetary integration in the Southern Cone. The North American Journal of Economics and Finance, 13(3), 323-349.

Belke, A., \& Setzer, R. (2003). Exchange rate variability and labor market performance in the Visegrad countries. Economics of Planning, 36(2), 153-175.

Belot, M., \& Van Ours, J. C. (2001). Unemployment and labor market institutions: an empirical analysis. Journal of the Japanese and International Economies, 15(4), 403418.

Belot, M., \& Van Ours, J. C. (2004). Does the recent success of some OECD countries in lowering their unemployment rates lie in the clever design of their labor market reforms?. Oxford Economic Papers, 56(4), 621-642. 
Berlemann, M., \& Hielscher, K. (2013). Effective Monetary Policy Conservatism: A Comparison of 13 OECD Countries. Scottish Journal of Political Economy, 60(3), 267290.

Blanchard, O., \& Giavazzi, F. (2003). Macroeconomic Effects of Regulation and Deregulation in Goods and Labor Markets. The Quarterly Journal of Economics, $118(3), 879-907$.

Blanchard, O., \& Wolfers, J. (2000). The role of shocks and institutions in the rise of European unemployment: the aggregate evidence. The Economic Journal, 110(462), 133.

Bleaney, M. (1996). Central bank independence, wage-bargaining structure, and macroeconomic performance in OECD countries. Oxford Economic Papers, 48(1), 2038 .

Botero, J., Djankov, S., Porta, R., \& Lopez-de-Silanes, F. (2004). The Regulation of Labor. The Quarterly Journal of Economics, 119(4), 1339-1382.

Bratsiotis, G., \& Martin, C. (1999). Stabilisation, policy targets and unemployment in imperfectly competitive economies. The Scandinavian Journal of Economics, 101(2), 241-256.

Brown, S., \& Taylor, K. (2013). Reservation wages, expected wages and unemployment. Economics Letters, 119(3), 276-279.

Calmfors, L. (2001). Unemployment, labor market reform, and monetary union. Journal of Labor Economics, 19(2), 265-289.

Calmfors, L., \& Driffill, J. (1988). Bargaining structure, corporatism and macroeconomic performance. Economic Policy, 3(6), 13-61.

Caprio, G., Klingebiel, D., Laeven, L. \& Noguera, G. (2005). Banking Crises Database. In Honahan, P. \& Laeven, L. (Eds.). Systemic Financial Crises, Cambridge, 307-340.

Ciccarone, G., Marchetti, E., \& Di Bartolomeo, G. (2007). Unions, Fiscal Policy and Central Bank Transparency. The Manchester School, 75(5), 617-633.

Cooley, T., \& Hansen, G. (1989). The Inflation Tax in a Real Business Cycle Model. American Economic Review, 79(4), 733-748.

Coricelli, F., Cukierman, A., \& Dalmazzo, A. (2006). Monetary Institutions, Monopolistic Competition, Unionized Labor Markets and Economic Performance. The Scandinavian Journal of Economics, 108(1), 39-63.

Cukierman, A. (1992). Central bank strategy, credibility, and independence: Theory and evidence. MIT press.

Cukierman, A. (2008). Central bank independence and monetary policymaking institutionsPast, present and future. European Journal of Political Economy, 24(4), 722-736.

Cukierman, A., \& Dalmazzo, A. (2006). Fiscal-monetary policy interactions in the presence of unionized labor markets. International Tax and Public Finance, 13(4), 411-435.

Cukierman, A., \& Lippi, F. (1999). Central bank independence, centralization of wage bargaining, inflation and unemployment: Theory and some evidence. European Economic Review, 43(7), 1395-1434.

Cunningham, S. R., Tang, H., \& Vilasuso, J. R. (1997). A time series analysis of the relationship between inflation uncertainty and unemployment. Journal of Macroeconomics, 19(4), 731-751. 
Daveri, F., \& Tabellini, G. (2000). Unemployment, growth and taxation in industrial countries. Economic Policy, 15(30), 48-104.

de Serres, A., \& Murtin, F. (2013). Do Policies that Reduce Unemployment Raise its Volatility?: Evidence from OECD Countries (No. 1020). OECD Publishing.

Demertzis, M. (2004). Central Bank independence: Low inflation at no cost? A numerical simulations exercise. Journal of Macroeconomics, 26(4), 661-677.

Demertzis, M., \& Hallett, A. H. (2007). Central bank transparency in theory and practice. Journal of Macroeconomics, 29(4), 760-789.

Demertzis, M., \& Hallett, A. H. (2007). Central bank transparency in theory and practice. Journal of Macroeconomics, 29(4), 760-789.

Demirgüç-Kunt, A., \& Detragiache, E. (2005). Cross-country Empirical Studies of Systemic Bank Distress: a Survey. National Institute Economic Review, 192(1), 68-83.

Di Tella, R., \& MacCulloch, R. (2004). Unemployment benefits as a substitute for a conservative Central Banker. The Review of Economics and Statistics, 86(4), 911-922.

Di Tella, R., \& MacCulloch, R. (2005). The consequences of labor market flexibility: Panel evidence based on survey data. European Economic Review, 49(5), 1225-1259.

Dincer, N. N., \& Eichengreen, B. (2007). Central bank transparency: where, why, and with what effects? (No. w13003). National Bureau of Economic Research.

Dincer, N. N., \& Eichengreen, B. (2014). Central Bank Transparency and Independence: Updates and New Measures. International Journal of Central Banking, 10(1), 189-259.

Dutt, P., Mitra, D., \& Ranjan, P. (2009). International trade and unemployment: Theory and cross-national evidence. Journal of International Economics, 78(1), 32-44.

Eijffinger, S. C. W., Hoeberichts, M. M., \& Schaling, E. (2000). Why money talks and wealth whispers: Monetary uncertainty and mystique. Journal of Money, Credit and Banking, 32(2), 218-235.

Eijffinger, S. C., \& Geraats, P. M. (2006). How transparent are central banks?. European Journal of Political Economy, 22(1), 1-21.

Faccini, R., \& Rosazza Bondibene, C. (2012). Labour market institutions and unemployment volatility: evidence from OECD countries (No. 461). Bank of England.

Fatás, A., Mihov, I., \& Rose, A. K. (2007). Quantitative goals for monetary policy. Journal of Money, Credit and Banking, 39(5), 1163-1176.

Felbermayr, G., Prat, J., \& Schmerer, H. J. (2011). Trade and unemployment: What do the data say?. European Economic Review, 55(6), 741-758.

Feldmann, H. (2011a). Central bank independence, wage bargaining, and labor market performance: new evidence. Southern Economic Journal, 77(3), 692-725.

Feldmann, H. (2011b). The unemployment effect of exchange rate volatility in industrial countries. Economics Letters, 111(3), 268-271.

Feldmann, H. (2012). Inflation volatility and unemployment in industrial countries. Applied Economics, 44(1), 49-64.

Freeman, R. B. (1992). Labor market institutions and policies: help or hindrance to economic development?. The World Bank Economic Review, 6(suppl 1), 117-144.

Friedman, M. (1977). Nobel lecture: inflation and unemployment. Journal of Political Economy, 85(3), 451-472. 
Froyen, R. T., Havrilesky, T., \& Waud, R. N. (1997). The asymmetric effects of political pressures on US monetary policy. Journal of Macroeconomics, 19(3), 471-493.

Garibaldi, P., \& Violante, G. L. (2005). The employment effects of severance payments with wage rigidities. The Economic Journal, 115(506), 799-832.

Garrett, G., \& Way, C. (1999). Public sector unions, corporatism, and macroeconomic performance. Comparative Political Studies, 32(4), 411-434.

Geraats, P. M. (2005). Transparency and Reputation: The Publication of Central Bank Forecasts. The BE Journal of Macroeconomics, 5(1), 1-28.

Golden, M. (1993). The dynamics of trade unionism and national economic performance. American Political Science Review, 87(02), 439-454.

Griffith, R., Harrison, R., \& Macartney, G. (2007). Product Market Reforms, Labour Market Institutions and Unemployment. The Economic Journal, 117(519), C142-C166.

Grüner, H. P. (2002). How much should central banks talk?: A new argument. Economics Letters, 77(2), 195-198.

Grüner, H. P., Hayo, B., \& Hefeker, C. (2009). Unions, Wage Setting and Monetary Policy Uncertainty. The BE Journal of Macroeconomics, 9(1), 1-25.

Guzzo, V., \& Velasco, A. (1999). The case for a populist central banker. European Economic Review, 43(7), 1317-1344.

Gwartney, J., Lawson, R., \& Hall, J. (2014). Economic freedom of the world 2014 annual report. The Fraser Institute.

Hall, P. A., \& Franzese, R. J. (1998). Mixed signals: central bank independence, coordinated wage bargaining, and European Monetary Union. International Organization, 52(3), 505-535.

Hefeker, C., \& Neugart, M. (2014). The Influence of Central Bank Transparency on Labor Market Regulation. The Manchester School, 82(1), 17-32.

Herrendorf, B., \& Neumann, M. J. (2003). The political economy of inflation, labour market distortions and central bank independence. The Economic Journal, 113(484), 43-64.

Herro, N., \& Murray, J. (2013). Dynamics of Monetary Policy Uncertainty and the Impact on the Macroeconomy. Economics Bulletin, 33(1), 257-270.

Hoeberichts, M., Tesfaselassie, M. F., \& Eijffinger, S. (2008). Central bank communication and output stabilization. Oxford Economic Papers, 61(2), 395-411.

International Labour Organization (2014). Global Wage Report 2014/15: Wages and income inequality, Geneva.

International Monetary Fund (2003). Unemployment and Labor Market Institutions: Why Reforms Pay Off, World Economic Outlook, Chapter IV, April.

Iversen, T. (1998a). Wage bargaining, central bank independence, and the real effects of money. International Organization, 52(3), 469-504.

Iversen, T. (1998b). Wage bargaining, hard money and economic performance: Theory and evidence for organized market economies. British Journal of Political Science, 28(1), 31-61.

Jones, A. T., \& Snyder, M. W. (2014). Federal Reserve independence: the Fed Funds Rate under different regimes. Applied Economics Letters, 21(18), 1262-1265.

Jordahl, H., \& Laséen, S. (2005). Central bank conservatism and labor market regulation. European Journal of Political Economy, 21(2), 345-363. 
Kilponen, J. (1999). Central Bank Independence and Wage Bargaining Structure-Empirical Evidence (No. 9/1999). Bank of Finland.

Kose, M. A. (2002). Explaining business cycles in small open economies:'How much do world prices matter?'. Journal of International Economics, 56(2), 299-327.

Kremer, S., Bick, A., \& Nautz, D. (2013). Inflation and growth: new evidence from a dynamic panel threshold analysis. Empirical Economics, 44(2), 861-878.

Kydland, F. E., \& Prescott, E. C. (1977). Rules rather than discretion: The inconsistency of optimal plans. The Journal of Political Economy, 85(3), 473-491.

Laeven, L., \& Valencia, F. (2013). Systemic Banking Crises Database. IMF Economic Review, 61(2), 225-270.

Laskar, D. (2010). Central bank transparency and shocks. Economics Letters, 107(2), 158160.

Lawler, P. (2000). Centralised wage setting, inflation contracts, and the optimal choice of central banker. The Economic Journal, 110(463), 559-575.

Layard, R., Nickell, S. J., \& Jackman, R. (2005). Unemployment: Macroeconomic Performance and the Labour Market. Oxford University Press on Demand.

Lippi, F. (2002). Revisiting the case for a populist central banker. European Economic Review, 46(3), 601-612.

Lochner, B. (2014). Employment protection in dual labor markets: Any amplification of macroeconomic shocks? (No. 14/2014). Friedrich-Alexander-Universität ErlangenNürnberg, Institut für Wirtschaftspolitik und Quantitative Wirtschaftsforschung (IWQW).

Muto, I. (2013). Productivity growth, transparency, and monetary policy. Journal of Economic Dynamics and Control, 37(1), 329-344.

Nickell, S. (1997). Unemployment and labor market rigidities: Europe versus North America. The Journal of Economic Perspectives, 11(3), 55-74.

Nickell, S., Nunziata, L., \& Ochel, W. (2005). Unemployment in the OECD Since the 1960s. What Do We Know?. The Economic Journal, 115(500), 1-27.

Oostendorp, R. H. (2012). The Occupational Wages around the World (OWW) Database: Update for 1983-2008.

Palley, T. I. (2004). The causes of high unemployment: labor market sclerosis versus macroeconomic policy. Challenging the market: the struggle to regulate work and income.

Reagan, P., \& Stulz, R. M. (1993). Contracting costs, inflation, and relative price variability. Journal of Money, Credit and Banking, 25(3), 585-601.

Rodrik, D. (1999). Democracies Pay Higher Wages. The Quarterly Journal of Economics, 114(3), 707-738.

Rogoff, K. (1985). The optimal degree of commitment to an intermediate monetary target. The Quarterly Journal of Economics, 100(4), 1169-1189.

Sala, H., Silva, J. I., \& Toledo, M. (2012). Flexibility at the margin and labor market volatility in OECD countries. The Scandinavian Journal of Economics, 114(3), 991-1017.

Sánchez, M. (2011). Robust central banking under wage bargaining: Is monetary policy transparency beneficial?. Economic Modelling, 28(1), 432-438. 
Sánchez, M. (2012). Inflation uncertainty and unemployment uncertainty: Why transparency about monetary policy targets matters. Economics Letters, 117(1), 119-122.

Seyfried, W. L., \& Ewing, B. T. (2001). Inflation uncertainty and unemployment: Some international evidence. The American Economist, 45(2), 33-39.

Skott, P. (1997). Stagflationary consequences of prudent monetary policy in a unionized economy. Oxford Economic Papers, 49(4), 609-622.

Sørensen, J. R. (1991): Political uncertainty and macroeconomic performance. Economics Letters, 37(4), 377-381.

Soskice, D., \& Iversen, T. (2000). The nonneutrality of monetary policy with large price or wage setters. The Quarterly Journal of Economics, 115(1), 265-284.

Spyromitros, E., \& Zimmer, B. (2009). Monetary accommodation and unemployment: Why central bank transparency matters. Economics Letters, 102(2), 119-121.

Visser, J. (2015). ICTWSS Data base. Version 5.0. Amsterdam: Amsterdam Institute for Advanced Labour Studies AIAS.

Westelius, N. J. (2009). Imperfect transparency and shifts in the central bank's output gap target. Journal of Economic Dynamics and Control, 33(4), 985-996.

Wood, A. (1995). North-South Trade, Employment, and Inequality: Changing Fortunes in a Skill-driven World. New York: Clarendon Press.

Yang, B., \& Lester, D. (2000). An exploration of the impact of culture on the economy: an empirical study of unemployment. The Journal of Socio-Economics, 29(3), 281-290.

Yeyati, E. L. (2003). On the impact of a common currency on bilateral trade. Economics Letters, 79(1), 125-129. 


\section{Appendix}

\section{Table A.1: Determinants of Annual Wages}

\begin{tabular}{|c|c|c|c|c|c|c|c|c|}
\hline Variable & wa1 & wa2 & wa3 & wa4 & wa5 & wa6 & wa7 & wa8 \\
\hline Dep. Var. & mthly_earnings & mthly_earnings (2) & mthly_earnings (2) & mthly_earnings (2) & mthly_earnings (2) & mthly_earnings (2) & mthly_earnings (2) & mthly_earnings (2) \\
\hline$\overline{\mathrm{CBT}}$ & & $-12106.03^{* * *}$ & & & $-5195.91^{*}$ & $-6016.69^{*}$ & $-7853.16^{* * * *}$ & * $-9510.98^{* * * *}$ \\
\hline$(\mathrm{t}-1)$ & -930.66 & & $-13123.23^{* * *}$ & $-12768.48 * *$ & & & & \\
\hline $\mathrm{CBT}^{2}$ & & & & & & & & \\
\hline CBI & & -6776.30 & & & & 8575.83 & -1544.29 & 2989.98 \\
\hline$(\mathrm{t}-1)$ & 30611.61 & & -10661.88 & -13729.17 & -20790.59 & & & \\
\hline GDP per capita & $0.11 * * *$ & $0.13^{* * *} *$ & $0.13 * * *$ & $0.13 * * *$ & $0.14 * * *$ & $0.14 * * *$ & $0.14 * * *$ & $0.14 * * *$ \\
\hline GDP Growth & $-1452.70 * * *$ & -288.17 & -121.13 & -289.20 & -606.13 & -658.27 & $-1588.66 * *$ & $-1953.57 * *$ \\
\hline Economic Freedom & & 15051.05 & 20604.15 & $41473.70 * *$ & & & & \\
\hline Inflation & & & & $3246.91 * *$ & & & & \\
\hline Coordination & & & & & -5255.78 & & & \\
\hline CBT x Coordination & & & & & 688.29 & & & \\
\hline Growth in Manufacturing Value Added & & & & & & -86.47 & -13.83 & -62.65 \\
\hline Labour Market Regulation & & & & & & $-9060.25^{*}$ & & \\
\hline Union Density (1) & & & & & & & $-704.36 * *$ & \\
\hline CBT x Union Density (1) & & & & & & & $113.56 * *$ & \\
\hline Union Density (2) & & & & & & & & -1602.01 \\
\hline CBT x Union Density (2) & & & & & & & & $133.68 * *$ \\
\hline Constant & $-85435.27 * * *$ & -76744.21 & -108962.11 & $-271632.56 * *$ & -14626.09 & 47122.26 & $-29642.61 *$ & -28134.93 \\
\hline $\mathrm{N}$ & 394 & 517 & 561 & 523 & 245 & 430 & 263 & 187 \\
\hline Groups & 36 & 57 & 57 & 56 & 22 & 48 & 26 & 20 \\
\hline $\mathrm{F}$ & 195.426 & 29.256 & 18.462 & 16.783 & 334.374 & 55.166 & 350.378 & 248.590 \\
\hline $\mathrm{R}^{2}$ & 0.90 & 0.50 & 0.38 & 0.39 & 0.97 & 0.71 & 0.97 & 0.97 \\
\hline
\end{tabular}


Table A.1: Determinants of Annual Wages (continued)

\begin{tabular}{|c|c|c|c|c|c|c|c|c|c|c|c|c|c|c|}
\hline Variable & wa9 & wa10 & wa11 & wa12 & wa13 & wa & & wa1 & & wa16 & & wa17 & wa & 18 \\
\hline Dep. Var. & real_mthly_earnings & real_mthly_earnings_gr & hw3wu ${ }^{1}$ & hw4wu ${ }^{1}$ & hw3wl ${ }^{1}$ & hw3wu & & hw4wut & & hw3wlus & & hw3wlus ${ }^{1}$ & hw4wl & \\
\hline$\overline{\mathrm{CBT}}$ & $-16785.88^{* * * *}$ & -1.38 & & & & & & & & -0.22 & * & & & \\
\hline$(\mathrm{t}-1)$ & & & $-1129.01 * * *$ & $-1168.27 * * *$ & $-1131.27 * * *$ & $*-0.29$ & ** & -0.26 & ** & & & -0.30 & $* *-0.26$ & ** \\
\hline $\begin{array}{l}\mathrm{CBT}^{2} \\
(\mathrm{t}-1)\end{array}$ & & & & & & & & & & & & & & \\
\hline$(\mathrm{t}-1)$ & & & $-9100.11 * *$ & $-9397.20 * *$ & $-9060.19 * *$ & 10.63 & & $* * 12.98$ & $* * *$ & & & 10.79 & $* * * 13.16$ & **** \\
\hline GDP per capita & $0.03 * * *$ & 0.00 & 0.00 & 0.00 & 0.00 & 0.00 & $*$ & 0.00 & * & 0.00 & $* *$ & 0.00 & $* 0.00$ & \\
\hline GDP Growth & $-3486.09 * *$ & $0.51 * * *$ & 94.73 & 98.26 & 98.46 & -0.06 & & -0.06 & & -0.08 & $* *$ & -0.06 & -0.06 & \\
\hline Growth in Manufacturing Value Added & 6.40 & 0.07 & & & & & & & & & & & & \\
\hline Labour Market Regulation & -16414.29 & & & & & & & & & & & & & \\
\hline $\mathrm{N}$ & 149 & 213 & 251 & 251 & 251 & & & 24 & 47 & 278 & & 247 & & 47 \\
\hline Groups & 18 & 45 & 44 & 44 & 44 & & 3 & & 43 & 44 & 4 & 43 & & 43 \\
\hline $\mathrm{F}$ & 5.79 & 4.13 & 2.87 & 2.88 & 2.86 & 19. & & 19.0 & & 17.70 & & 19.66 & 19. & 15 \\
\hline $\mathrm{R}^{2}$ & 0.45 & 0.22 & 0.16 & 0.16 & 0.16 & 0. & & 0.5 & & 0.53 & & 0.57 & & 57 \\
\hline
\end{tabular}

Table A.1: Determinants of Annual Wages (continued)

\begin{tabular}{|c|c|c|c|c|c|c|c|c|c|c|c|c|}
\hline Variable & wa19 & wa20 & wa21 & wa22 & wa23 & wa24 & wa25 & wa26 & wa27 & wa28 & wa29 & wa30 \\
\hline Dep. Var. & $\mathrm{mw} 3 \mathbf{w u}^{1}$ & $\mathrm{mw} 4 \mathbf{w u}^{1}$ & $\mathrm{mw}^{\mathrm{mwl}} \mathbf{l}^{1}$ & mw4wl ${ }^{1}$ & hw2wuus $^{1}$ & mw2wuus $^{1}$ & mw3wuus $^{1}$ & mw3wuus $^{1}$ & mw3wuus $^{1}$ & mw4wuus $^{1}$ & mw4wuus $^{1}$ & mw4wuus $^{1}$ \\
\hline$\overline{\mathrm{CBT}}$ & & & & & & $-283.71 * * *$ & & $-204.22 * * *$ & & & & $-210.16^{* * *}$ \\
\hline$(\mathrm{t}-1)$ & $-193752.14 * * *$ & * $-201826.14 * * *$ & $-194093.50 * * *$ & $-202031.14 * * *$ & $-0.96 * *$ & & $-46.13 * *$ & & $-187.40 * * *$ & $-189.14 * * *$ & $-46.45^{* *}$ & \\
\hline $\mathrm{CBT}^{2}$ & & & & & & $18.23^{* * *}$ & & 13.49 *** & & & & $14.17 * * *$ \\
\hline$(\mathrm{t}-1)$ & & & & & $0.06^{*}$ & & & & $12.12 * * *$ & $12.62 * * *$ & & \\
\hline CBI & & & & & & $1279.12 * * *$ & & $1310.31 * * *$ & & & & $1799.50 * * *$ \\
\hline$(\mathrm{t}-1)$ & $-1539922.20^{* *}-$ & $-1589886.00^{* *}$ & $-1532200.00^{* *}$ & $-1576115.10^{* *}$ & $11.39^{* * * *}$ & & $1843.49^{* * *}$ & & $1900.19^{* * *}$ & $2473.18 * * *$ & $2384.94 * * *$ & \\
\hline GDP per capita & 0.16 & 0.18 & 0.16 & 0.16 & $0.00 * *$ & 0.00 & $0.00 * *$ & $0.00 * *$ & $0.00^{* *}$ & $0.00^{* *}$ & $0.00^{* *}$ & $0.00^{* *}$ \\
\hline GDP Growth & 16197.06 & 16953.62 & 16764.32 & 17422.19 & 0.00 & 1.21 & -8.38 & -4.36 & -0.65 & 0.32 & -7.73 & -4.42 \\
\hline Growth in Manufacturing Value Added & & & & & 0.01 & 2.85 & & 0.53 & 0.29 & 0.48 & & 0.44 \\
\hline Consta & $1970011.40^{* * * *}$ & $2002860.30 * * *$ & $1963618.70^{* * * *}$ & $2019107.30^{* * *}$ & 2.08 & $1023.40 * * *$ & 177.50 & $735.05^{* * * *}$ & $493.44 * *$ & 247.25 & -54.74 & $554.93 * * *$ \\
\hline $\mathrm{N}$ & 251 & 251 & 251 & 251 & 152 & 145 & 247 & 243 & 215 & 215 & 247 & 243 \\
\hline Groups & 44 & 44 & 44 & 44 & 26 & 26 & 43 & 39 & 38 & 38 & 43 & 39 \\
\hline $\mathrm{F}$ & 2.91 & 2.94 & 2.90 & 2.88 & 11.79 & 9.56 & 21.20 & 14.64 & 16.53 & 16.39 & 20.75 & 13.60 \\
\hline $\mathrm{R}^{2}$ & 0.16 & 0.16 & 0.16 & 0.16 & 0.61 & 0.60 & 0.59 & 0.55 & 0.60 & 0.60 & 0.59 & 0.54 \\
\hline
\end{tabular}


Table A.1: Determinants of Annual Wages (continued)

\begin{tabular}{|c|c|c|c|c|c|c|c|c|}
\hline Variable & wa31 & wa32 & wa33 & wa34 & wa35 & wa36 & wa37 & wa38 \\
\hline Dep. Var. & mw2wlus $^{1}$ & mw2wlus $^{1}$ & mw2wlus $^{1}$ & mw3wlus $^{1}$ & mw3wlus $^{1}$ & mw4wlus $^{1}$ & md_hw2wuus ${ }^{2}$ & md_hw2wuus ${ }^{2}$ \\
\hline$\overline{\mathrm{CBT}}$ & $-283.85^{* * * *}$ & & & $-203.92 * * *$ & & $-207.66 * * *$ & $-1.40^{* * * *}$ & \\
\hline$(\mathrm{t}-1)$ & & $-204.48 * *$ & $-219.95 * *$ & & $-187.34 * * *$ & & & $-0.89 *$ \\
\hline $\mathrm{CBT}^{2}$ & $18.04 * * *$ & & & $13.34 * * *$ & & $14.15^{* * * *}$ & $0.09 * * *$ & \\
\hline$(\mathrm{t}-1)$ & & $12.84 * *$ & $13.80^{* *}$ & & $11.94 * * *$ & & & $0.06^{*}$ \\
\hline CBI & $1331.00 * * *$ & & & $1358.12 * * *$ & & $1770.35^{* * *}$ & $7.14 * * *$ & \\
\hline$(\mathrm{t}-1)$ & & $1888.76 * * *$ & $1878.44 * * *$ & & $1977.67 * * *$ & & & $10.97 * * *$ \\
\hline GDP per capita & $0.00 *$ & $0.00 *$ & $0.00 *$ & $0.00 * *$ & $0.00 * *$ & $0.00 * *$ & $0.00 * *$ & $0.00 * *$ \\
\hline GDP Growth & 1.19 & 2.99 & 1.61 & -4.16 & -0.14 & -4.16 & 0.00 & 0.02 \\
\hline Growth in Manufacturing Value Added & 3.01 & & 2.00 & 0.38 & 0.14 & 0.58 & 0.01 & 0.01 \\
\hline Constant & $1002.74 * * *$ & $513.57 *$ & $650.99 * *$ & $716.37 * * *$ & $460.66 * *$ & $576.06^{* * *}$ & $4.40 * * *$ & 1.48 \\
\hline $\mathrm{N}$ & 145 & 139 & 129 & 243 & 215 & 243 & 170 & 152 \\
\hline Groups & 26 & 26 & 23 & 39 & 38 & 39 & 28 & 26 \\
\hline $\mathrm{F}$ & 9.40 & 13.15 & 11.35 & 14.49 & 16.62 & 13.32 & 7.83 & 10.03 \\
\hline $\mathrm{R}^{2}$ & 0.59 & 0.65 & 0.65 & 0.55 & 0.61 & 0.53 & 0.50 & 0.58 \\
\hline
\end{tabular}

Table A.1: Determinants of Annual Wages (continued)

\begin{tabular}{|c|c|c|c|c|c|c|c|c|}
\hline Variable & wa39 & wa40 & wa41 & wa42 & wa43 & wa44 & wa45 & wa46 \\
\hline Dep. Var. & md hw3wuus ${ }^{2}$ & md hw3wuus ${ }^{2}$ & md hw4wuus ${ }^{2}$ & md hw4wuus ${ }^{2}$ & md hw2wlus ${ }^{2}$ & md hw2wlus ${ }^{2}$ & md hw3wlus ${ }^{2}$ & md hw3wlus ${ }^{2}$ \\
\hline CBT & $-0.98^{* * *}$ & & $-1.00^{* * *}$ & & $-1.40^{* * *}$ & & $-0.98^{* * *}$ & \\
\hline$(\mathrm{t}-1)$ & & $-0.89^{* * *}$ & & $-0.87 * *$ & & $-0.91 *$ & & $-0.90 * * *$ \\
\hline $\mathrm{CBT}^{2}$ & $0.06^{* * * *}$ & & $0.07 * * *$ & & $0.09 * * *$ & & $0.06^{* * * *}$ & \\
\hline$(\mathrm{t}-1)$ & & $0.06 * *$ & & $0.06^{* *}$ & & $0.06 *$ & & $0.06 * *$ \\
\hline CBI & $7.13^{* * *}$ & & $8.82 * * *$ & & $7.28 * * *$ & & $7.28 * * *$ & \\
\hline$(\mathrm{t}-1)$ & & $10.59 * * *$ & & $12.77 * * *$ & & $11.15^{* * * *}$ & & $10.79^{* * * *}$ \\
\hline GDP per capita & $0.00 * *$ & $0.00 * *$ & $0.00 * *$ & $0.00 * *$ & $0.00 * *$ & $0.00 * *$ & $0.00 * *$ & $0.00 * *$ \\
\hline GDP Growth & -0.02 & 0.00 & -0.02 & 0.01 & 0.00 & 0.02 & -0.02 & 0.01 \\
\hline Growth in Manufacturing Value Added & 0.00 & 0.00 & 0.00 & 0.00 & 0.01 & 0.01 & 0.00 & -0.01 \\
\hline Constant & $3.56 * * *$ & $2.03 *$ & $2.93 * *$ & 1.08 & $4.31 * *$ & 1.40 & $3.47 * * *$ & $1.93^{*}$ \\
\hline $\mathrm{N}$ & 243 & 215 & 243 & 215 & 170 & 152 & 243 & 215 \\
\hline Groups & 39 & 38 & 39 & 38 & 28 & 26 & 39 & 38 \\
\hline $\mathrm{F}$ & 11.53 & 13.51 & 10.96 & 13.61 & 7.85 & 10.10 & 11.57 & 13.61 \\
\hline $\mathrm{R}^{2}$ & 0.50 & 0.56 & 0.48 & 0.56 & 0.50 & 0.58 & 0.50 & 0.56 \\
\hline
\end{tabular}


Table A.1: Determinants of Annual Wages (continued)

\begin{tabular}{|c|c|c|c|c|c|c|c|c|}
\hline Variable & wa47 & wa48 & wa49 & wa50 & wa51 & wa52 & wa53 & wa54 \\
\hline Dep. Var. & md_hw4wlus ${ }^{2}$ & md_hw4wlus ${ }^{2}$ & md_mw2wuus ${ }^{2}$ & md_mw2wuus ${ }^{2}$ & md_mw3wuus ${ }^{2}$ & md_mw3wuus ${ }^{2}$ & md_mw4wuus ${ }^{2}$ & md_mw4wuus ${ }^{2}$ \\
\hline$\overline{\mathrm{CBT}}$ & $-1.00^{* * * *}$ & & $-258.14^{* * *}$ & & $-173.47^{* * *}$ & & $-180.68^{* * * *}$ & \\
\hline$(\mathrm{t}-1)$ & & $-0.88^{* *}$ & & $-202.22 * *$ & & $-169.86 * * *$ & & $-172.17 * * *$ \\
\hline $\mathrm{CBT}^{2}$ & $0.07 * * *$ & & $16.06^{* *}$ & & $10.86^{* * * *}$ & & $11.51^{* * * *}$ & \\
\hline$(\mathrm{t}-1)$ & & $0.06^{* *}$ & & $12.59^{* *}$ & & $10.41 * * *$ & & $10.84 * *$ \\
\hline CBI & $8.90^{* * *}$ & & $1219.56^{* * *}$ & & $1252.37 * * *$ & & $1693.63 * * *$ & \\
\hline$(\mathrm{t}-1)$ & & $12.88^{* * *}$ & & $1773.49^{* * *}$ & & $1834.03 * * *$ & & $2356.87 * * *$ \\
\hline GDP per capita & $0.00 * *$ & $0.00^{* *}$ & 0.00 & $0.00 * *$ & $0.00 * *$ & $0.00^{* *}$ & $0.00 * *$ & $0.00 * *$ \\
\hline GDP Growth & -0.01 & 0.01 & 1.81 & 3.23 & -2.80 & 1.45 & -2.14 & 2.98 \\
\hline Growth in Manufacturing Value Added & 0.00 & -0.01 & 2.40 & 1.72 & -0.78 & -0.99 & -1.22 & -1.25 \\
\hline Constant & $2.89 * *$ & 1.04 & $885.39 * *$ & $541.05 *$ & $601.19 * * *$ & $381.85 * *$ & $448.14 * *$ & 165.86 \\
\hline $\mathrm{N}$ & 243 & 215 & 145 & 129 & 243 & 215 & 243 & 215 \\
\hline Groups & 39 & 38 & 26 & 23 & 39 & 38 & 39 & 38 \\
\hline $\mathrm{F}$ & 11.15 & 13.95 & 7.08 & 8.64 & 11.60 & 13.69 & 11.12 & 13.92 \\
\hline $\mathrm{R}^{2}$ & 0.49 & 0.56 & 0.52 & 0.59 & 0.50 & 0.56 & 0.49 & 0.56 \\
\hline
\end{tabular}

Table A.1: Determinants of Annual Wages (continued)

\begin{tabular}{|c|c|c|c|c|c|c|}
\hline Variable & wa55 & wa56 & wa57 & wa58 & wa59 & wa60 \\
\hline Dep. Var. & md_mw2wlus²md & mw2wlus $2 \mathrm{~m}$ & d_mw3wlus ${ }^{2} n$ & nd_mw3wlus ${ }^{2} n$ & nd_mw4wlus ${ }^{2} n$ & md_mw4wlus ${ }^{2}$ \\
\hline$\overline{\mathrm{CBT}}$ & -252.70 & & -170.73 & & -177.01 & \\
\hline$(\mathrm{t}-1)$ & & -201.27 & & -169.19 & & -171.76 \\
\hline $\mathrm{CBT}^{2}$ & 15.64 & & 10.65 & & 11.36 & \\
\hline$(\mathrm{t}-1)$ & & 12.43 & & 10.29 & & 10.71 \\
\hline CBI & 1210.29 & & 1246.45 & & 1668.75 & \\
\hline$(\mathrm{t}-1)$ & & 1788.72 & & 1851.15 & & 2413.52 \\
\hline GDP per capita & 0.00 & 0.00 & 0.00 & 0.00 & 0.00 & 0.00 \\
\hline GDP Growth & 1.56 & 3.30 & -2.95 & 1.51 & -2.04 & 3.11 \\
\hline Growth in Manufacturing Value Added & 2.37 & 1.79 & -0.77 & -0.94 & -1.27 & -1.31 \\
\hline Constant & 860.68 & 514.85 & 584.03 & 357.48 & 452.10 & 154.83 \\
\hline $\mathrm{N}$ & 145 & 129 & 243 & 215 & 243 & 215 \\
\hline Groups & 26 & 23 & 39 & 38 & 39 & 38 \\
\hline $\mathrm{F}$ & 7.17 & 8.87 & 11.76 & 14.02 & 10.78 & 14.13 \\
\hline $\mathrm{R}^{2}$ & 0.53 & 0.59 & 0.50 & 0.56 & 0.48 & 0.57 \\
\hline
\end{tabular}

Notes: The table shows the results of fixed effects estimations with robust standard errors where the dependent variable is the respective wage. The asterisks indicate whether a coefficient is significantly different from zero $10 \%$ (one asterisk), $5 \%$ (two asterisks) or $1 \%$ (three asterisks) significance level. 


\section{Variable Descriptions:}

${ }^{1}$ : Mean over all observations per year

2: Median over all observations per year

mthly_earnings: Mean nominal monthly earnings of employees by sex

mthly_earnings (2): Mean nominal monthly earnings of employees by type of scenario

real_mthly_earnings: Mean real monthly earnings of employees by type of scenario

real_mthly_earnings_gr: Mean real monthly earnings of employees, annual growth

hw3wu: hourly wage (local currency) with country-specific and uniform calibration (type 3, uni weighting) hw4wu: hourly wage (local currency) with uniform calibration (type 4, uni weighting)

hw3wl: hourly wage (local currency) with country-specific and uniform calibration (type 3, lex weighting)

hw2wuus: hourly wage (US Dollar) with country-specific calibration (type 2, uni weighting)

hw3wuus: hourly wage (US Dollar) with country-specific calibration (type 3, uni weighting)

hw4wuus: hourly wage (US Dollar) with country-specific and uniform calibration (type 4, uni weighting)

hw2wlus: hourly wage (US Dollar) with country-specific and uniform calibration (type 2, lex weighting)

hw3wlus: hourly wage (US Dollar) with uniform calibration (type 3, lex weighting)

hw4wlus: hourly wage (US Dollar) with uniform calibration (type 4, lex weighting)

mw3wu: monthly wage (local currency) with country-specific and uniform calibration (type 3, uni weighting) mw4wu: monthly wage (local currency) with uniform calibration (type 4, uni weighting)

mw3wl: monthly wage (local currency) with country-specific and uniform calibration (type 3, lex weighting) mw4wl: monthly wage (local currency) with uniform calibration (type 4, lex weighting) mw2wuus: monthly wage (US Dollar) with country-specific calibration (type 2, uni weighting) mw3wuus: monthly wage (US Dollar) with country-specific calibration (type 3, uni weighting) mw4wuus: monthly wage (US Dollar) with country-specific and uniform calibration (type 4, uni weighting) mw2wlus: monthly wage (US Dollar) with country-specific and uniform calibration (type 2, lex weighting) mw3wlus: monthly wage (US Dollar) with uniform calibration (type 3, lex weighting) mw4wlus: monthly wage (US Dollar) with uniform calibration (type 4, lex weighting) md_hw2wuus: hourly wage (US Dollar) with country-specific calibration (type 2, uni weighting) md hw3wuus: hourly wage (US Dollar) with country-specific calibration (type 3, uni weighting) md_hw4wuus: hourly wage (US Dollar) with country-specific and uniform calibration (type 4, uni weighting) md_hw2wlus: hourly wage (US Dollar) with country-specific and uniform calibration (type 2, lex weighting) md hw3wlus: hourly wage (US Dollar) with uniform calibration (type 3, lex weighting) md_hw4wlus: hourly wage (US Dollar) with uniform calibration (type 4, lex weighting) md_mw2wuus: monthly wage (US Dollar) with country-specific calibration (type 2, uni weighting) md mw3wuus: monthly wage (US Dollar) with country-specific calibration (type 3, uni weighting) md_mw4wuus: monthly wage (US Dollar) with country-specific and uniform calibration (type 4, uni weighting) md_mw2wlus: monthly wage (US Dollar) with country-specific and uniform calibration (type 2, lex weighting) md_mw3wlus: monthly wage (US Dollar) with uniform calibration (type 3, lex weighting) md_mw4wlus: monthly wage (US Dollar) with uniform calibration (type 4, lex weighting) 
Further information about the weightings of the respective variables can be found in Oostendorp, 2012 
Table A.2: Determinants of Unemployment - Panel Averages

\begin{tabular}{|c|c|c|c|c|c|c|c|c|c|c|c|c|c|c|c|c|}
\hline Variable & ols1 & & ols2 & & ols3 & ols4 & ols5 & & ols6 & & ols7 & & ols8 & & ols9 & \\
\hline CBT & 1.7315 & **** & 1.9795 & *** & 1.2357 & 1.1084 & 1.8752 & *** & 1.8068 & ** & 2.1066 & *** & 2.0467 & ** & 2.2597 & *** \\
\hline CBT $^{2}$ & -0.1346 & **** & -0.1528 & *** & -0.0808 & -0.0908 & -0.1466 & ** & -0.1129 & ** & -0.1598 & **** & -0.1563 & $* * *$ & -0.1692 & $* * *$ \\
\hline CBI & & & 5.3830 & \# & 1.6352 & 2.3040 & 5.3938 & \# & 3.4039 & & 4.8062 & & 4.7643 & & 4.1691 & \\
\hline Union density & & & & & -0.0181 & & & & & & & & & & & \\
\hline UB gross replacement rate, average year 1-2 & & & & & & 6.1599 & & & & & & & & & & \\
\hline Openness & & & & & & & 0.0057 & & 0.0093 & & 0.0033 & & 0.0027 & & 0.0022 & \\
\hline Money growth & & & & & & & -0.0100 & & -0.0100 & & 0.1586 & & 0.1640 & & 0.2400 & \\
\hline GDP growth & & & & & & & & & -0.1944 & & -0.2384 & & -0.2391 & & -0.4436 & \\
\hline GDP per capita (US \$) & & & & & & & & & -0.0002 & **** & & & & & & \\
\hline GDP per capita (LCU) & & & & & & & & & & & 0.0000 & $* *$ & 0.0000 & ** & 0.0000 & $* *$ \\
\hline Inflation & & & & & & & & & & & -0.2019 & & -0.2058 & & -0.2970 & \\
\hline Terms of Trade & & & & & & & & & & & & & -0.0121 & & & \\
\hline Exchange rate growth & & & & & & & & & & & & & & & 0.0002 & $* * *$ \\
\hline Population & & & & & & & & & & & & & & & & \\
\hline Real interest rate & & & & & & & & & & & & & & & & \\
\hline Bank Assets to GDP & & & & & & & & & & & & & & & & \\
\hline Minimum wage to mean wage (ratio) & & & & & & & & & & & & & & & & \\
\hline Legal system \& property rights & & & & & & & & & & & & & & & & \\
\hline Labour market regulations & & & & & & & & & & & & & & & & \\
\hline Constant & 4.6442 & $* * *$ & 2.2430 & & 3.5133 & 4.0927 & 2.3038 & & 4.3455 & \# & 1.9528 & & 3.4393 & & 1.9154 & \\
\hline $\mathbf{N}$ & 108 & & 81 & & 33 & 49 & 80 & & 80 & & 79 & & 79 & & 79 & \\
\hline Adjusted R ${ }^{2}$ & 0.029 & & 0.060 & & -0.063 & 0.001 & 0.032 & & 0.069 & & 0.028 & & 0.015 & & 0.063 & \\
\hline $\mathbf{R}^{2}$ & 0.048 & & 0.095 & & 0.069 & 0.084 & 0.093 & & 0.151 & & 0.128 & & 0.128 & & 0.172 & \\
\hline $\mathbf{F}$ & 5.1514 & & 4.0911 & & 2.1792 & 4.1453 & 2.5863 & & 2.8603 & & 1.8444 & & 1.6613 & & 50.2634 & \\
\hline
\end{tabular}

Notes: The table shows the results of ordinary least squares estimations with robust standard errors where the dependent variable is the unemployment rate. All data are averages of the respective country's values. The asterisks indicate whether a coefficient is significantly different from zero at the $20 \%$ (hashtag), $10 \%$ (one asterisk), $5 \%$ (two asterisks) or $1 \%$ (three asterisks) significance level. 
Table A.2: Determinants of Unemployment - Panel Averages (continued)

\begin{tabular}{|c|c|c|c|c|c|c|c|c|c|c|}
\hline Variable & ols 10 & & ols11 & & ols12 & & ols13 & & ols14 & \\
\hline CBT & 1.9928 & *** & 1.0752 & & -0.4442 & & 1.0062 & & 1.0944 & \\
\hline CBT $^{2}$ & -0.1466 & ** & -0.0691 & & 0.0033 & & -0.0505 & & -0.0534 & \\
\hline CBI & 3.5898 & & -0.3365 & & 0.9809 & & -1.3187 & & -1.1195 & \\
\hline \multicolumn{11}{|c|}{ Union density } \\
\hline \multicolumn{11}{|c|}{ UB gross replacement rate, average year 1-2 } \\
\hline Openness & 0.0033 & & -0.0113 & & -0.0050 & & 0.0118 & & 0.0116 & \\
\hline Money growth & 0.2556 & & 0.5018 & \# & 0.2197 & ** & 0.4943 & \# & 0.5097 & \# \\
\hline GDP growth & -0.3672 & & -0.6992 & & -0.2923 & & -0.7392 & \# & -0.7166 & \# \\
\hline \multicolumn{11}{|l|}{ GDP per capita (US \$) } \\
\hline GDP per capita (LCU) & 0.0000 & \# & 0.0000 & & 0.0000 & & 0.0000 & & 0.0000 & \\
\hline Inflation & -0.3035 & & -0.4621 & & 0.0108 & & -0.3384 & & -0.3115 & \\
\hline \multicolumn{11}{|l|}{ Terms of Trade } \\
\hline Exchange rate growth & 0.0002 & $* * *$ & -0.1364 & & -0.2106 & \# & -0.2889 & $* *$ & -0.3236 & $* *$ \\
\hline Population & 0.0000 & \# & 0.0000 & & 0.0000 & ** & 0.0000 & \# & 0.0000 & \\
\hline Real interest rate & 0.1429 & & 0.1329 & & 0.0397 & & 0.1038 & & 0.0788 & \\
\hline Bank Assets to GDP & & & -0.0278 & * & & & & & & \\
\hline Minimum wage to mean wage (ratio) & & & & & 7.3426 & ** & & & & \\
\hline Legal system \& property rights & & & & & & & -1.8131 & $*$ & -1.9447 & * \\
\hline Labour market regulations & & & & & & & & & 0.3681 & \\
\hline Constant & 1.2558 & & 7.5921 & & 6.7765 & \# & 14.4661 & ** & 12.0968 & $*$ \\
\hline $\mathbf{N}$ & 75 & & 45 & & 39 & & 68 & & 68 & \\
\hline Adjusted R ${ }^{2}$ & 0.051 & & 0.101 & & 0.235 & & 0.065 & & 0.052 & \\
\hline $\mathbf{R}^{2}$ & 0.192 & & 0.346 & & 0.477 & & 0.232 & & 0.236 & \\
\hline $\mathbf{F}$ & & & 1.8911 & & 5.7129 & & 4.4670 & & 3.6738 & \\
\hline
\end{tabular}

Notes: The table shows the results of ordinary least squares estimations with robust standard errors where the dependent variable is the unemployment rate. All data are averages of the respective country's values. The asterisks indicate whether a coefficient is significantly different from zero at the $20 \%$ (hashtag), $10 \%$ (one asterisk), $5 \%$ (two asterisks) or $1 \%$ (three asterisks) significance level. 
Table A.3: Determinants of Unemployment

\begin{tabular}{|c|c|c|c|c|c|c|c|c|c|c|c|c|c|c|c|c|c|c|c|c|}
\hline Variable & fe1 & & re1 & & fe2 & & re2 & & fe3 & & re3 & & fe4 & & re4 & & fe5 & & re5 & \\
\hline CBT & & & & & & & & & -0.7666 & **** & -0.5301 & *** & -0.6636 & $* * *$ & -0.4924 & *** & -0.7969 & **** & -0.6049 & **** \\
\hline $\mathrm{CBT}^{2}$ & & & & & & & & & 0.0521 & $* * *$ & 0.0385 & $* * *$ & 0.0467 & $* * *$ & 0.0382 & ** & 0.0501 & **** & 0.0394 & **** \\
\hline Central Bank Independence & & & & & & & & & 3.4190 & $* *$ & 2.9979 & $* *$ & 4.4316 & $* *$ & 4.0703 & ** & 3.1983 & ** & 2.9795 & ** \\
\hline Inflation & -0.0083 & * & -0.0088 & * & -0.0076 & & -0.0086 & & -0.0065 & & -0.0085 & & -0.0465 & & -0.0454 & & -0.0122 & * & -0.0128 & * \\
\hline Terms of Trade & -0.0035 & & -0.0034 & & 0.0018 & & 0.0015 & & 0.0028 & & 0.0021 & & 0.0036 & & 0.0012 & & 0.0030 & & 0.0023 & \\
\hline Real Interest Rate & -0.0023 & & -0.0030 & & -0.0102 & & -0.0114 & & -0.0123 & & -0.0142 & & -0.0065 & & -0.0076 & & -0.0088 & & -0.0097 & \\
\hline GDP Growth & 0.0037 & & 0.0027 & & 0.0272 & & 0.0264 & & 0.0349 & $*$ & 0.0339 & & -0.0222 & & -0.0218 & & 0.0220 & & 0.0236 & \\
\hline$(\mathrm{t}-1)$ & -0.0611 & $* * *$ & -0.0623 & **** & -0.1031 & $* * *$ & -0.1041 & $* * *$ & -0.1016 & $* * *$ & -0.1024 & **** & -0.1170 & $* * *$ & -0.1215 & $* * *$ & -0.1003 & **** & -0.1016 & **** \\
\hline GDP per Capita & -0.0002 & $* * *$ & -0.0001 & $* * *$ & -0.0002 & $* *$ & -0.0002 & $* * *$ & -0.0003 & $* * *$ & -0.0002 & $* * *$ & -0.0003 & $* * *$ & -0.0002 & $* * *$ & -0.0003 & **** & -0.0002 & $* * *$ \\
\hline Centralised Collective Bargaining & & & & & & & & & & & & & -0.0721 & & -0.1428 & & & & & \\
\hline Uncoordinated Bargaining & & & & & & & & & & & & & & & & & 2.3276 & & 1.5008 & \\
\hline State Imposed / Sponsored Bargaining & & & & & & & & & & & & & & & & & & & -1.0073 & \\
\hline Openness & & & & & & & & & & & & & 0.0325 & $* * *$ & 0.0244 & $* * *$ & 0.0367 & $* * *$ & 0.0318 & **** \\
\hline
\end{tabular}

State Imposed / Sponsored Bargaining

Legal System \& Property Rights

Freedom to Trade

Credit Market Regulations

Business Regulations

Government Effectiven

Population Growth

Rural Populatio

Banking Crisis

Private Sector Credit

SD M2 Growth (yearly)

SD M2 Growth (monthly)

SD Inflation (monthly)

SD ER Growth (monthly)

Constant $\begin{array}{llllll}11.4710 & * * * & 10.4491 & * * * & 11.8720 & * * *\end{array}$ $13.0209 * * *$

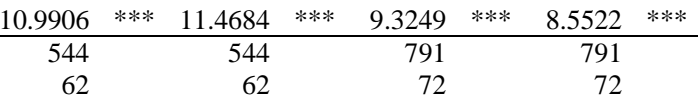

N $1352 \quad 1352$

$\begin{array}{rr}352 & 715 \\ 141 & 72\end{array}$

141

F

$\mathbf{R}^{2}$
AIC

0.118

0.077

715
72
6.215
0.137
2983.0
3060.8

715
72

711

711
72

544
62
5.306

791
72
7.156

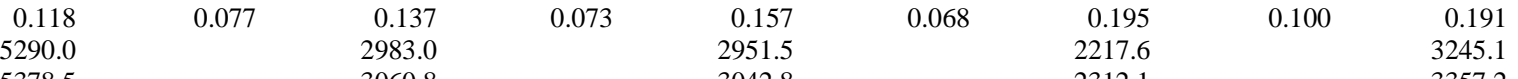

Notes: The table shows the results of fixed and random effects estimations with robust standard errors where the dependent variable is the unemployment rate. The asterisks indicate whether a coefficient is significantly different from zero at the $10 \%$ (one asterisk), $5 \%$ (two asterisks) or $1 \%$ (three asterisks) significance level. 
Table A.3: Determinants of Unemployment (continued)

\begin{tabular}{|c|c|c|c|c|c|c|c|c|c|c|}
\hline Variable & fe6 & re6 & fe7 & re7 & fe8 & re8 & fe9 & re9 & fe10 & re10 \\
\hline$\overline{\text { CBT }}$ & $-0.8913^{* *}$ & $-0.6646^{*}$ & -0.2791 & 0.4483 & 0.5922 & 0.6052 & $-3.7425 *$ & $-5.5012^{* * * *}$ & $* 0.1725$ & $3.5856^{* * * *}$ \\
\hline $\mathrm{CBT}^{2}$ & $0.0610^{* * * *}$ & $0.0490 * *$ & 0.0204 & -0.0185 & -0.0273 & -0.0288 & $0.2035 *$ & $0.2000^{*}$ & -0.0004 & $-0.2397 * * *$ \\
\hline Central Bank Independence & $4.6051 *$ & 2.2398 & 6.9013 & $-4.4899 *$ & 2.1465 & 2.1257 & 3.1818 & 1.3464 & 2.6342 & $-5.1959 * * *$ \\
\hline Inflation & $-0.1309 * * *$ & $-0.1254 * *$ & $*_{-} 0.0953 *$ & $0.1565^{* *}$ & -0.0087 & -0.0009 & $-0.2742 * *$ & -0.1053 & 0.0156 & $0.6192 * * *$ \\
\hline Terms of Trade & -0.0168 & -0.0154 & $-0.0230^{* * *}$ & $*-0.0190$ & $-0.0113 *$ & $-0.0108 *$ & -0.0171 & 0.0294 & -0.0106 & $0.0296 *$ \\
\hline Real Interest Rate & 0.0249 & 0.0281 & $-0.1437 * * *$ & $*-0.1557 * *$ & -0.0043 & -0.0013 & -0.0208 & 0.0571 & 0.0055 & $0.2382 * * *$ \\
\hline GDP Growth & -0.0531 & -0.0497 & $-0.1541 * * *$ & $*-0.3649 * * *$ & $*-0.1016 * * *$ & $*_{-0} 0.0996 * * *$ & $-0.1251 *$ & -0.1432 & $-0.1134 * *$ & -0.1036 \\
\hline$(t-1)$ & $-0.3827 * * *$ & $-0.3881 * *$ & $*_{-} 0.0748$ & $0.3767 * * *$ & $*-0.2674 * * *$ & $*_{-} 0.2671 * * *$ & $-0.2543 * *$ & 0.0198 & $-0.3228 * *$ & $*-0.2793 * *$ \\
\hline GDP per Capita & -0.0002 & $-0.0002 * *$ & & & & & & & & \\
\hline Social Pact regarding Employ & s- -0.0875 & -0.2462 & & & & & & & & \\
\hline
\end{tabular}

arding Employment Policies - $0.0875 \quad-0.2462$

Union Density

Union Density (alt)

$0.2742 * * *-0.0551$

$0.0144 \quad 0.1099$

Cent Density (alt 2)

Centralised Bargainin

CBT $2 *$ Union Density

CBI * Union Density

CBT * Uni Densty (alt)

CBT * Union Density (alt 2)

$\mathrm{CBT}^{2}$ * Union Density (alt 2)

CBT * Centralised Bargaining

$\mathrm{CBT}^{2} *$ Centralised Bargaining

Openness

$0.2742 .4+0.0551$

$0.0251 \quad 0.0260$

$-29.5078-78.3244 * * *$

$0.0055-0.0558^{* * *}$

$-0.0047 \quad-0.0049$

$0.0003 \quad 0.0003$

\begin{tabular}{llllllll}
$0.7391 *$ & 0.4086 & $1.2106 * * *$ & $1.2103 * * *$ & $1.6152 * * *$ & $1.7807 *$ & $0.8570 *$ & -1.3784 \\
\hline
\end{tabular}

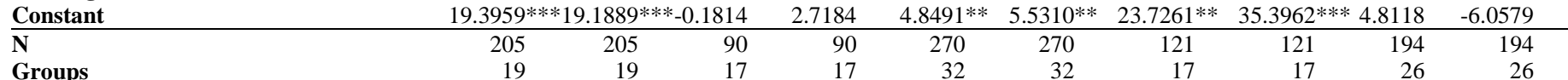

Groups

205
19

F

$\mathbf{R}^{2}$

12.391

$0.636 \quad 0.251$

BIC

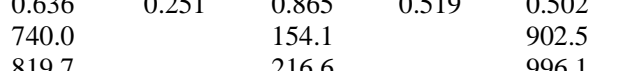

$32 \quad 17$

$\begin{array}{rrr}17 & 17 & 26 \\ 2.961 & & 6.976\end{array}$

$17-26$
0.976

514.5

Notes: The table shows the results of fixed and random effects estimations with robust standard errors where the dependent variable is the unemployment rate. The asterisks indicate whether a coefficient is significantly different from zero at the $10 \%$ (one asterisk), $5 \%$ (two asterisks) or $1 \%$ (three asterisks) significance level. 
Table A.3: Determinants of Unemployment (continued)

\begin{tabular}{|c|c|c|c|c|c|c|c|c|c|c|}
\hline Variable & fe11 & re11 & fe12 & re12 & fe13 & re13 & fe14 & re14 & fe15 & re15 \\
\hline CBT & $-0.7028 * * *$ & $-0.4842 * *$ & $-1.0662 * * *$ & $-0.7147 * * *$ & $-1.2968 * * *$ & $-0.7536^{* * * *}$ & $*-1.3856 * * *$ & $-0.7849 * *$ & $-0.6327 * * *$ & $-0.4018^{*}$ \\
\hline $\mathrm{CBT}^{2}$ & $0.0477 * * *$ & * $0.0370 * *$ & $0.0654 * * *$ & $0.0467 * * *$ & $0.0875^{* * *}$ & $0.0532^{* * * *}$ & $* 0.0850 * * *$ & $0.0512 * *$ & $0.0424 * * *$ & $0.0307 * *$ \\
\hline Central Bank Independence & $4.4707 * *$ & $3.6440 * *$ & $5.8431 * * *$ & $5.0125 * * *$ & $6.4745 * * *$ & $3.8550 * *$ & $11.2418 * * *$ & $5.9821 * *$ & $4.5770 * * *$ & $3.4723 * *$ \\
\hline Inflation & -0.0381 & -0.0399 & -0.0030 & -0.0077 & $-0.0475 * *$ & $-0.0539 * *$ & -0.0366 & -0.0729 & -0.0409 & $-0.0424 *$ \\
\hline Terms of Trade & 0.0046 & 0.0027 & 0.0085 & 0.0062 & 0.0104 & 0.0047 & 0.0071 & -0.0024 & 0.0052 & 0.0034 \\
\hline Real Interest Rate & -0.0007 & -0.0023 & -0.0044 & -0.0096 & -0.0072 & -0.0144 & -0.0028 & -0.0155 & 0.0014 & -0.0009 \\
\hline GDP Growth & -0.0239 & -0.0213 & -0.0059 & -0.0114 & -0.0154 & -0.0004 & -0.0263 & -0.0290 & -0.0140 & -0.0134 \\
\hline$(\mathrm{t}-1)$ & $-0.1141^{* * * *}$ & * $-0.1188 * * *$ & $*-0.1129 * * *$ & $=-0.1180^{* * * *}$ & $-0.0944 * * *$ & $-0.0951^{* * *}$ & $*-0.1252 * * *$ & -0.1341 *** & $-0.1045^{* * *}$ & $-0.1102 * * *$ \\
\hline GDP per Capita & $-0.0003 * * *$ & $*-0.0002 * * *$ & $*-0.0003 * * *$ & $-0.0002 * * *$ & $-0.0009 * * *$ & $-0.0003^{* * *} *$ & $*-0.0008 * * *$ & $-0.0003 * * *$ & $=-0.0004 * * *$ & $-0.0002 * * *$ \\
\hline Labour Market Regulations & $-0.3656^{*}$ & -0.2777 & & & & & & & & \\
\hline Taxes on Goods and Services & & & $-0.0628 * *$ & $-0.0589 * *$ & & & $-0.1241 * * *$ & $-0.1214 * * *$ & & \\
\hline Taxes on Products & & & & & 0.0000 & 0.0000 & $0.0000 * *$ & 0.0000 & & \\
\hline Openness & $0.0319 * * *$ & * $0.0231 * * *$ & & & & & $0.0473^{* * *}$ & $0.0488^{* * * *}$ & $0.0281 * * *$ & $0.0203 * * *$ \\
\hline $\begin{array}{l}\text { Legal System \& Property Rights } \\
\text { Freedom to Trade }\end{array}$ & & & & & & & & & -0.2561 & -0.1615 \\
\hline $\begin{array}{l}\text { Freedom to Trade } \\
\text { Credit Market Regulations }\end{array}$ & & & & & & & 00311 & 01885 & & \\
\hline Business Regulations & & & & & & & -0.0311 & 0.1885 & & \\
\hline Government Effectiveness & & & & & & & & & & \\
\hline Population Growth & & & & & & & & & & \\
\hline Rural Population & & & & & & & & & & \\
\hline Banking Crisis & & & & & & & $1.4225^{* *}$ & $1.3041 * *$ & & \\
\hline Private Sector Credit & & & & & & & & & & \\
\hline SD M2 Growth (yearly) & & & & & & & & & & \\
\hline SD M2 Growth (monthly) & & & & & & & & & & \\
\hline SD Inflation (monthly) & & & & & & & & & & \\
\hline SD ER Growth (monthly) & & & & & & & & & & \\
\hline Constant & $12.5199 * *$ & $* 11.6012 * * *$ & *15.7770*** & 12.7259 *** & $17.3044 * * * 1$ & 12.8821 *** & $22.2176 * * * 1$ & $17.5423 * * *$ & $12.6204 * * *$ & $11.0817 * * *$ \\
\hline $\mathbf{N}$ & 582 & 582 & 528 & 528 & 541 & 541 & 352 & 352 & 616 & 616 \\
\hline Groups & 66 & 66 & 66 & 66 & 58 & 58 & 46 & 46 & 66 & 66 \\
\hline $\mathbf{F}$ & 5.578 & & 5.054 & & 6.004 & & 4.771 & & 5.606 & \\
\hline $\mathbf{R}^{2}$ & 0.191 & 0.080 & 0.186 & 0.106 & 0.206 & 0.061 & 0.307 & 0.177 & 0.182 & 0.084 \\
\hline AIC & 2357.1 & & 2180.9 & & 2294.8 & & 1505.6 & & 2500.0 & \\
\hline BIC & 2453.1 & & 2270.6 & & 2380.7 & & 1606.1 & & 2597.3 & \\
\hline
\end{tabular}

Notes: The table shows the results of fixed and random effects estimations with robust standard errors where the dependent variable is the unemployment rate. The asterisks indicate whether a coefficient is significantly different from zero at the $10 \%$ (one asterisk), $5 \%$ (two asterisks) or $1 \%$ (three asterisks) significance level. 
Table A.3: Determinants of Unemployment (continued)

\begin{tabular}{|c|c|c|c|c|c|c|c|c|c|c|}
\hline Variable & fe16 & re16 & fe17 & re17 & fe18 & re18 & fe19 & re19 & fe20 & re20 \\
\hline CBT & $-0.5109^{* *}$ & -0.2936 & $-0.6827 * * *$ & -0.4138 & $-0.6786 * * *$ & -0.4008 & $-0.4598^{*}$ & -0.2817 & $-1.1613^{* * * *}$ & -0.5517 \\
\hline CBT $^{2}$ & $0.0325^{* *}$ & 0.0230 & $0.0455^{* * * *}$ & $0.0315^{* *}$ & $0.0450^{* * * *}$ & * $0.0316^{*}$ & $0.0329 *$ & 0.0223 & $0.0768^{* * *}$ & 0.0393 \\
\hline Central Bank Independence & $4.7058 * * *$ & * $3.4537 * *$ & $4.4347 * *$ & $3.4514 * *$ & $4.6561 * * *$ & * $3.4918 * *$ & 2.4979 & 2.5664 & $7.9042 * *$ & 4.2117 \\
\hline Inflation & -0.0400 & $-0.0427^{*}$ & $-0.0486^{*}$ & $-0.0461^{*}$ & $-0.0528 *$ & $-0.0518^{*}$ & -0.0119 & -0.0116 & $-0.0599 *$ & $-0.0700 * *$ \\
\hline Terms of Trade & 0.0015 & 0.0009 & 0.0045 & 0.0030 & 0.0046 & 0.0019 & 0.0040 & 0.0037 & $0.0190 * *$ & $0.0164 *$ \\
\hline Real Interest Rate & -0.0009 & -0.0030 & 0.0015 & -0.0007 & -0.0048 & -0.0079 & -0.0241 & -0.0228 & -0.0264 & -0.0284 \\
\hline GDP Growth & -0.0169 & -0.0149 & -0.0092 & -0.0109 & -0.0176 & -0.0186 & 0.0404 & $0.0423 *$ & -0.0238 & -0.0169 \\
\hline$(\mathrm{t}-1)$ & $-0.1060 * * *$ & $*-0.1112 * * *$ & $*-0.1034 * * *$ & $-0.1101 * * *$ & $-0.1105 * * *$ & ${ }^{*}-0.1168^{* * *}$ & $*-0.0718 * * *$ & $*-0.0735 * * *$ & $*-0.0825 *$ & $-0.0965^{* *}$ \\
\hline GDP per Capita & $-0.0004 * * *$ & $*-0.0002 * * *$ & $*-0.0004 * * *$ & $-0.0002 * * *$ & $-0.0004 * * *$ & $*-0.0002 * * *$ & $*-0.0003 * * *$ & $*-0.0002 *$ & $*-0.0008 * * * *$ & $-0.0003 * * *$ \\
\hline Labour Market Regulations & & & & & -0.3210 & -0.2136 & & & & \\
\hline Taxes on Goods and Services & & & & & & & & & $-0.0912 * *$ & $-0.0754 * *$ \\
\hline Taxes on Products & & & & & & & & & 0.0000 & 0.0000 \\
\hline Openness & $0.0308^{* * *}$ & * $0.0217 * * *$ & * $0.0274 * * *$ & $0.0195^{* *}$ & $0.0316^{* * *}$ & * $0.0225^{* * *}$ & $* 0.0235 * * *$ & * $0.0189 * *$ & $0.0403 * * *$ & $=0.0425^{* * *}$ \\
\hline \multicolumn{11}{|c|}{ Legal System \& Property Rights } \\
\hline Freedom to Trade & $-0.7377 * * * *$ & $*-0.5208 * *$ & & & & & & & & \\
\hline Regulations & & & $-0.2169 *$ & -0.1213 & $-0.2333 *$ & -0.1227 & & & & \\
\hline Busines & & & & & $-0.3374 *$ & $-0.3242 *$ & & & & \\
\hline ment Effectiveness & & & & & & & 0.2327 & 0.3398 & 1.7001 & $2.2124 * *$ \\
\hline Banking Cris & & & & & & & & & 0.6984 & 0.4868 \\
\hline Constant & $16.7389^{* * *}$ & ${ }^{*} 13.8090^{* * *}$ & $* 13.2366 * * * 1$ & $11.2910 * * *$ & $17.1121 * * *$ & *14.4552**** & $* 9.9204 * * *$ & $* 9.2733^{* * *}$ & *16.4031*** & $11.5141^{* * *}$ \\
\hline $\mathbf{N}$ & 615 & 615 & 616 & 616 & 572 & 572 & 511 & 511 & 279 & 279 \\
\hline Grou & 66 & 66 & 66 & 66 & 66 & 66 & 70 & 70 & 48 & 48 \\
\hline $\mathbf{F}$ & 6.104 & & 5.690 & & 5.435 & & 5.629 & & 3.983 & \\
\hline $\mathbf{R}^{2}$ & 0.195 & 0.083 & 0.184 & 0.078 & 0.206 & 0.082 & 0.193 & 0.078 & 0.285 & 0.137 \\
\hline AIC & 2486.9 & & 2498.4 & & 2318.3 & & 1967.0 & & 1121.8 & \\
\hline BIC & 2584.2 & & 2595.7 & & 2422.7 & & 2047.5 & & 1198.1 & \\
\hline
\end{tabular}

Notes: The table shows the results of fixed and random effects estimations with robust standard errors where the dependent variable is the unemployment rate. The asterisks indicate whether a coefficient is significantly different from zero at the $10 \%$ (one asterisk), $5 \%$ (two asterisks) or $1 \%$ (three asterisks) significance level. 
Table A.3: Determinants of Unemployment (continued)

\begin{tabular}{|c|c|c|c|c|c|c|c|c|c|c|}
\hline Tariable & fe21 & re21 & fe22 & re22 & fe23 & re23 & fe24 & re24 & fe25 & re25 \\
\hline$\overline{\text { CBT }}$ & $-1.4853 * * *$ & $-0.8411 * *$ & $-1.3025 * * *$ & $-0.7479 * *$ & $-0.8453^{* * *}$ & $*-0.6525 * *$ & -1.2537 *** & *-0.5817 & $-1.3476^{\text {*** }}$ & *-0.6814* \\
\hline $\mathrm{CBT}^{2}$ & $0.0927 * * *$ & * $0.0554 * *$ & $0.0804 * * *$ & $0.0495 * *$ & $0.0496 * * *$ & $* 0.0387 * *$ & $0.0772^{* * *}$ & $* 0.0401 *$ & $0.0838 * * *$ & $* 0.0464 *$ \\
\hline Central Bank Independence & $10.3548^{* * * *}$ & $4.8948 *$ & $9.9822 * * *$ & $4.6490 *$ & 3.1219 & 2.9470 & $12.2124 * * *$ & $* 5.1145^{*}$ & $14.6565^{* * * *}$ & * $6.2150 * *$ \\
\hline Inflat & -0.0297 & $-0.0718^{*}$ & -0.0359 & $-0.0749 *$ & -0.0064 & -0.0085 & $-0.0924 * *$ & $-0.1196^{* *}$ & -0.0365 & -0.0633 \\
\hline Ter & & -0.00 & & & & 0.0053 & 0.0146 & & 0.01 & 0.0072 \\
\hline & .0049 & -0.01 & -0.0098 & -0.0 & 0.0006 & -0.0022 & -0.0004 & -0.0 & 0.0088 & -0.0089 \\
\hline GDP Growth & -0.0069 & -0.0021 & -0.0182 & -0.0067 & $-0.0472 *$ & -0.0308 & -0.0069 & -0.0015 & -0.0273 & -0.0194 \\
\hline$(t-1)$ & $-0.1183^{* * * *}$ & $-0.1210 * * *$ & $*-0.1201 * * *$ & $-0.1215 * * *$ & $-0.0783 *$ & $*-0.0$ & $-0.1135^{* * *}$ & $*-0.1236 * * *$ & $*-0.0863 * *$ & $06^{* * *}$ \\
\hline GDP per $\mathrm{C}$ & $-0.0011 * * *$ & -0.00 & $*-0.0012 * * *$ & $-0.0003 * * *$ & & & $-0.0012 * * *$ & $*-0.0003 *$ & $*-0.0014 * * *$ & $*-0.0003 * * *$ \\
\hline & $-0.1105 * * *$ & $=-0.08$ & $*-0.0994 * * *$ & & & & $-0.1083 *$ & & & \\
\hline Tax & $0.0000 * *$ & 0.0000 & $0.0000 * * *$ & 0.0000 & & & $0.0000^{* * * *}$ & $* 0.0000$ & 0.0000 ** & 0.0000 \\
\hline Openness & $0.0371 * *$ & $0.0367^{* *}$ & $0.0391 * *$ & $0.0375 * * *$ & $0.0362 * * *$ & $* 0.0272 * *$ & $0.0511^{* * * *}$ & $* 0.0563 * * *$ & $0.0541 * * *$ & $* 0.0517 * * *$ \\
\hline
\end{tabular}

Openness

Legal System \& Prope
Freedom to Trade

Freedom to Trade

Credit Market Regulation
Business Regulations

Government Effectiveness

Population Growth

Rural Population

Banking Crisis

Private Sector Credit
SD M2 Growth (yearly)

SD M2 Growth (monthly)

SD Inflation (monthly)

SD ER Growth (monthly)

Constant

$-1.0046^{* * * *}-0.4715$

Groups

Grou
F
$\mathbf{R}^{2}$

$\mathbf{R}^{2}$

AIC

\begin{tabular}{|c|c|c|c|c|c|c|c|c|c|}
\hline \multirow{4}{*}{$\begin{array}{c}1.1477 * * * \\
-0.2455^{* *}\end{array}$} & & \multirow{4}{*}{$\begin{array}{c}1.1683^{* *} * \\
-0.2168 * *\end{array}$} & \multirow{4}{*}{$\begin{array}{r}0.9287 \\
-0.1689\end{array}$} & -0.2829 & $-0.4652 * *$ & \multirow{3}{*}{$1.3817 * *$} & \multirow{3}{*}{$1.0697^{*}$} & \multirow{3}{*}{0.3969} & \multirow{3}{*}{0.4196} \\
\hline & \multirow{3}{*}{$\begin{array}{c}0.9281 \\
-0.1848^{*}\end{array}$} & & & $\begin{array}{r}-0.5427 \\
0.7381\end{array}$ & $\begin{array}{r}-0.0059 \\
0.6588\end{array}$ & & & & \\
\hline & & & & & & & & & \\
\hline & & & & -0.0286 & -0.0315 & & & 01307 & 08 \\
\hline
\end{tabular}

$1.1020 * * \quad 0.8548 *$

$23.1752 * * * 17.0859 * * * 31.0359 * * * 20.2730 * * * 24.3852 * * * 9.0415 * * * 16.9475 * * *$

$\begin{array}{rrrrrrrrrr}390 & 390 & 390 & 390 & 499 & 499 & 338 & 338 & 300 & 300 \\ 49 & 49 & 49 & 49 & 57 & 57 & 47 & 47 & 43 & 43 \\ 5.581 & & 5.727 & & 4.208 & & 5.481 & & 4.454 & \\ 0.306 & 0.115 & 0.321 & 0.119 & 0.188 & 0.002 & 0.330 & 0.136 & 0.314 & 0.113 \\ 1642.3 & & 1635.9 & & 2086.1 & & 1455.5 & & 1310.2 & \\ 1741.4 & & 1739.0 & & 2187.2 & & 1547.3 & & 1399.1 & \end{array}$

Notes: The table shows the results of fixed and random effects estimations with robust standard errors where the dependent variable is the unemployment rate. The asterisks indicate whether a coefficient is significantly different from zero at the $10 \%$ (one asterisk), $5 \%$ (two asterisks) or $1 \%$ (three asterisks) significance level. 
Table A.3: Determinants of Unemployment (continued)

\begin{tabular}{|c|c|c|c|c|c|c|}
\hline Variable & fe26 & re26 & fe27 & re27 & fe28 & re28 \\
\hline CBT & $-1.2483 * * *_{-}$ & -0.4835 & $-1.1388 * * *$ & $*_{-}-0.5536$ & $-1.3883 * * *$ & $-0.7545 * *$ \\
\hline $\mathrm{CBT}^{2}$ & $0.0763^{* * *}$ & 0.0336 & $0.0702 * * *$ & $* 0.0382$ & $0.0861 * * *$ & $0.0505^{* *}$ \\
\hline Central Bank Independence & $10.3257 * * *$ & $5.8787 * *$ & 11.8386 *** & $* 5.7866 * *$ & $10.8743^{* * * *}$ & $5.1409 *$ \\
\hline Inflation & $-0.0534 \quad-$ & $-0.0707 * *$ & $-0.0983 * *$ & $-0.1200^{* *}$ & -0.0436 & $-0.0794 *$ \\
\hline Terms of Trade & $0.0166^{*}$ & 0.0118 & $0.0172 *$ & 0.0139 & 0.0067 & -0.0033 \\
\hline Real Interest Rate & -0.0012 & -0.0143 & -0.0040 & -0.0201 & -0.0004 & -0.0116 \\
\hline GDP Growth & -0.0147 & -0.0006 & -0.0042 & 0.0083 & -0.0178 & -0.0167 \\
\hline$(\mathrm{t}-1)$ & $-0.1042 * * *$ & $-0.1049 * * *$ & $*-0.1131 * * *$ & $*-0.1155 * * *$ & $*-0.1160 * * *$ & $-0.1224 * * *$ \\
\hline GDP per Capita & $-0.0009 * * *$ & $-0.0002 * * *$ & $*-0.0010$ *** & $*-0.0003 * * *$ & $*-0.0009 * * *$ & $-0.0002 * * *$ \\
\hline Labour Market Regulations & & & & & -0.0953 & -0.3024 \\
\hline Taxes on Goods and Services & s $-0.1122 * * *$ & $-0.0935 * * *$ & $*-0.1205^{* * *}$ & $*-0.1161 * * *$ & $*-0.1152 * * *$ & $-0.1088 * * *$ \\
\hline Taxes on Products & $0.0000^{* *}$ & 0.0000 & $0.0000 * *$ & 0.0000 & $0.0000 * *$ & 0.0000 \\
\hline Openness & $0.0534 * * *$ & $0.0564 * * *$ & * $0.0593 * * *$ & $* 0.0625^{* * *} *$ & $* 0.0415 * *$ & $0.0411 * * *$ \\
\hline Credit Market Regulations & & & & & -0.0818 & 0.1611 \\
\hline Banking Crisis & $1.0238^{*}$ & 0.9186 & $1.2962 * *$ & 1.0064 & $1.3461 * *$ & $1.2799 * *$ \\
\hline SD Inflation (monthly) & & & $1.0875^{* *}$ & $0.9256^{* *}$ & & \\
\hline SD ER Growth (monthly) & $0.2626^{* *}$ & $0.3634 * * *$ & * 0.2415 & $0.3868 * * *$ & & \\
\hline Constant & $15.6395^{* * * *}$ & & $14.5545^{* * *}$ & $* 7.1156 *$ & $20.6208 * * *$ & $15.6901 * * *$ \\
\hline$\overline{\mathbf{N}}$ & 357 & 357 & 310 & 310 & 374 & 374 \\
\hline Groups & 49 & 49 & 43 & 43 & 49 & 49 \\
\hline F & 5.276 & & 4.915 & & 5.060 & \\
\hline $\mathbf{R}^{2}$ & 0.308 & 0.159 & 0.337 & 0.163 & 0.306 & 0.140 \\
\hline AIC & 1517.4 & & 1349.9 & & 1589.0 & \\
\hline BIC & 1610.4 & & 1443.3 & & 1691.0 & \\
\hline
\end{tabular}

Notes: The table shows the results of fixed and random effects estimations with robust standard errors where the dependent variable is the unemployment rate. The asterisks indicate whether a coefficient is significantly different from zero at the $10 \%$ (one asterisk), $5 \%$ (two asterisks) or $1 \%$ (three asterisks) significance level. 
Table A.4: Determinants of Unemployment - 1998 to 2005

\begin{tabular}{|c|c|c|c|c|c|c|c|c|c|c|c|c|c|c|}
\hline Variable & fe1 & re1 & fe2 & re2 & fe3 & re3 & fe4 & re4 & fe5 & re5 & fe6 & re6 & fe7 & re7 \\
\hline CBT (t-1) & & & & & -0.3373 & -0.1798 & $-0.6510 * *$ & -0.2026 & -0.3060 & -0.2090 & -0.1733 & 0.2678 & $0.9676^{* *}$ & -1.1307 \\
\hline $\mathrm{CBT}^{2}(\mathrm{t}-1)$ & & & & & $0.0352 * *$ & 0.0243 & $0.0657^{* * *}$ & 0.0328 & $0.0388^{*}$ & $0.0321 *$ & 0.0523 & 0.0005 & $-0.0643 * *$ & 0.0265 \\
\hline CBI (t-1) & & & & & $3.1749^{*}$ & $2.8193^{*}$ & $5.5455^{* *}$ & $3.6883^{*}$ & 2.4207 & 1.5249 & -3.0748 & -0.4346 & 0.1071 & $-10.7650^{* *}$ \\
\hline Inflation & -0.0055 & -0.0057 & -0.0086 & -0.0088 & -0.0093 & -0.0096 & $-0.0422 *$ & $-0.0393^{*}$ & -0.0315 & -0.0286 & 0.0089 & -0.0458 & -0.0381 & -0.2337 \\
\hline Terms of Trade & -0.0065 & -0.0064 & 0.0012 & 0.0014 & -0.0018 & -0.0008 & 0.0026 & -0.0023 & 0.0059 & 0.0062 & -0.0088 & -0.0001 & 0.0115 & 0.0823 \\
\hline Real interest rate & 0.0008 & 0.0003 & -0.0218 & -0.0220 & -0.0235 & -0.0232 & $-0.0365^{*}$ & $-0.0362^{*}$ & -0.0321 & -0.0362 & -0.0490 & -0.0329 & 0.0481 & $0.7651 * * *$ \\
\hline GDP growth & 0.0124 & 0.0133 & 0.0364 & 0.0386 & $0.0535^{* *}$ & $0.0545^{* *}$ & 0.0125 & 0.0237 & 0.0461 & 0.0412 & 0.1342 & 0.0399 & -0.0898 & -0.5509 \\
\hline$(\mathrm{t}-1)$ & $-0.0231 * * *$ & $*-0.0234 * * *$ & $*-0.0582 * * *$ & $*-0.0577 * * *$ & $*-0.0611 * * *$ & $-0.0611 * * *$ & $* 0.0033$ & 0.0068 & 0.0146 & -0.0006 & -0.0791 & -0.1079 & $-0.1148 * * *$ & ${ }^{k}-0.1159$ \\
\hline GDP per capita & -0.0001 & $-0.0001 * * *$ & $*-0.0002 *$ & $-0.0002 * * *$ & $*-0.0003 * *$ & $-0.0002 * * *$ & $-0.0008 * * *$ & $-0.0003 * * *$ & $*-0.0002$ & $-0.0002 * *$ & $*-0.0004$ & $-0.0003^{* *}$ & & \\
\hline Net taxes on products & & & & & & & 0.0000 & 0.0000 & 0.0000 & 0.0000 & 0.0000 & 0.0000 & & \\
\hline Taxes on goods and services & & & & & & & & & -0.0182 & -0.0207 & -0.1001 & -0.0794 & & \\
\hline Openness & & & & & & & & & 0.0135 & 0.0071 & -0.0231 & 0.0077 & $0.0625 * *$ & $0.0777 * *$ \\
\hline Advanced notice & & & & & & & & & $5.5567^{* *}$ & $* 4.7444 * *$ & & & & \\
\hline Banking Crisis & & & & & & & & & -0.3722 & -0.2773 & -0.4802 & -0.4329 & 0.5384 & -0.8926 \\
\hline Minimum wage to mean wage ratio & & & & & & & & & & & 1.5336 & 1.1854 & & \\
\hline Minimum wage to median wage ratio & & & & & & & & & & & & & $-9.0694 * *$ & 4.3566 \\
\hline UB gross replacement rate year 1 & & & & & & & & & & & & & 5.2652 & 7.2315 \\
\hline UB gross replacement rate year 2 & & & & & & & & & & & & & $78.2937 * * * \ldots$ & -13.9035 \\
\hline \multicolumn{15}{|c|}{ UB gross replacement rate, average year 1-2 } \\
\hline \multicolumn{15}{|c|}{ Population growth } \\
\hline \multirow{2}{*}{\multicolumn{15}{|c|}{ Rural population (\% of total) }} \\
\hline \multicolumn{2}{|l|}{ SD M2 growth (yearly) } & & & & & & & & & & & & & \\
\hline \multirow{2}{*}{\multicolumn{15}{|c|}{ SD Inflation (monthly) }} \\
\hline \multicolumn{8}{|l|}{ SD M2 growth (monthly) } & & & & & & & \\
\hline \multicolumn{15}{|l|}{ SD ER growth (monthly) } \\
\hline Constant & $10.5826^{* * *}$ & & $11.5358^{* * *}$ & & $11.9510^{* * *}$ & $10.5588^{* * *}$ & $15.6815^{* * * *}$ & $11.6543 * * *$ & * 3.4706 & 5.0844 & $18.6486 *$ & $* 12.6639 * *$ & $*-1.7710$ & -0.5729 \\
\hline $\mathbf{N}$ & 854 & 854 & 428 & 428 & 400 & 400 & 308 & 308 & 139 & 139 & 107 & 107 & 69 & 69 \\
\hline Groups & 132 & 132 & 66 & 66 & 66 & 66 & 51 & 51 & 28 & 28 & 23 & 23 & 11 & 11 \\
\hline $\mathbf{R}^{2}$ & 0.062 & 0.061 & 0.066 & 0.067 & 0.070 & 0.075 & 0.056 & 0.070 & 0.309 & 0.318 & 0.089 & 0.239 & 0.003 & 0.600 \\
\hline AIC & 2791.3 & & 1470.5 & & 1377.6 & & 1100.4 & & 374.0 & & 331.6 & & 94.0 & \\
\hline BIC & 2857.8 & & 1527.4 & & 1441.4 & & 1160.1 & & 432.6 & & 385.1 & & 138.7 & \\
\hline
\end{tabular}

Notes: The table shows the results of fixed and random effects estimations with robust standard errors where the dependent variable is the unemployment rate. The asterisks indicate whether a coefficient is significantly different from zero at the $10 \%$ (one asterisk), $5 \%$ (two asterisks) or $1 \%$ (three asterisks) significance level. 
Table A.4: Determinants of Unemployment - 1998 to 2005 (continued)

\begin{tabular}{|c|c|c|c|c|c|c|c|c|c|c|c|c|c|c|}
\hline Variable & fe8 & re8 & fe9 & re9 & fe10 & re10 & fe11 & re11 & fe12 & re12 & fe13 & re13 & fe14 & re14 \\
\hline$\overline{\text { CBT }(t-1)}$ & -0.1695 & $\begin{array}{l}-0.1618 \\
\end{array}$ & -0.3315 & $\begin{array}{l}-0.1858 \\
\end{array}$ & $-0.9449 * *$ & $-0.6496^{*}$ & -0.4657 & -0.2984 & $-0.5999 *$ & -0.2953 & $-0.7728^{*}$ & -0.5646 & $\begin{array}{l}-0.3823 \\
\end{array}$ & -0.2726 \\
\hline $\mathrm{CBT}^{2}(\mathrm{t}-1)$ & 0.0269 & 0.0217 & $0.0309^{*}$ & 0.0204 & $0.0782 * * *$ & * $0.0597 * * *$ & $0.0524 * *$ & $0.0406^{*}$ & $0.0612 * * *$ & $0.0412 * *$ & $0.0725 * * *$ & $0.0600^{* * * *}$ & * $0.0336 *$ & 0.0266 \\
\hline CBI (t-1) & -0.1887 & 0.8581 & 1.5778 & 1.5207 & 4.5684 & 2.9039 & 3.6859 & 3.2330 & 2.9909 & 3.2730 & 3.3898 & 3.2323 & 2.5712 & $2.9227 * *$ \\
\hline Inflation & -0.0242 & -0.0227 & -0.0025 & -0.0035 & -0.0627 & $-0.0808^{*}$ & -0.0396 & -0.0447 & -0.0379 & $-0.0493 *$ & -0.0741 & $-0.0974 * *$ & -0.0089 & -0.0095 \\
\hline Terms of Trade & 0.0072 & 0.0057 & 0.0059 & 0.0052 & 0.0158 & 0.0144 & 0.0167 & 0.0154 & $0.0316^{*}$ & 0.0255 & 0.0224 & 0.0182 & 0.0099 & 0.0090 \\
\hline Real interest rate & -0.0119 & -0.0091 & -0.0006 & 0.0014 & -0.0442 & -0.0436 & -0.0055 & -0.0037 & -0.0274 & -0.0263 & -0.0393 & -0.0413 & -0.0262 & -0.0254 \\
\hline GDP growth & 0.0189 & 0.0171 & -0.0205 & -0.0167 & 0.0276 & 0.0267 & 0.0222 & 0.0225 & 0.0197 & 0.0270 & 0.0422 & 0.0449 & 0.0074 & 0.0044 \\
\hline$(t-1)$ & -0.0233 & -0.0248 & -0.0366 & -0.0253 & -0.0471 & -0.0429 & -0.0366 & -0.0341 & -0.0599 & -0.0440 & -0.0394 & -0.0266 & $-0.0593^{*}$ & $-0.0614 * *$ \\
\hline GDP per capita & & & & & $-0.0007 * * *$ & $-0.0003^{* * *}$ & $=-0.0005$ & $-0.0003 * *$ & $-0.0006 * *$ & $-0.0003 * * *$ & $-0.0005 *$ & $-0.0003 * * *$ & $-0.0003 * *$ & $-0.0002 * * *$ \\
\hline Net taxes on products & & & & & 0.0000 & 0.0000 & 0.0000 & 0.0000 & 0.0000 & 0.0000 & 0.0000 & 0.0000 & & \\
\hline Taxes on goods and services & & & & & -0.0673 & -0.0684 & -0.0665 & -0.0623 & -0.0464 & -0.0418 & -0.0653 & $-0.0727 *$ & -0.0385 & -0.0396 \\
\hline Openness & -0.0039 & -0.0074 & -0.0080 & -0.0072 & -0.0165 & -0.0029 & -0.0087 & -0.0031 & -0.0186 & -0.0017 & -0.0216 & -0.0002 & & \\
\hline Advanced notice & & & & & & & & & & & & & & \\
\hline Banking Crisis & & & -0.0353 & -0.3165 & -0.3754 & -0.5665 & -1.4379 & -1.3770 & -0.6002 & -0.7598 & -0.7332 & -0.9340 & & \\
\hline Minimum wage to mean wage ratio & & & & & & & & & & & & & & \\
\hline Minimum wage to median wage ratio & & & & & & & & & & & & & & \\
\hline UB gross replacement rate year 1 & & & & & & & & & & & & & & \\
\hline UB gross replacement rate year 2 & & & & & & & & & & & & & & \\
\hline UB gross replacement rate, average year 1 & $-2-6.6527$ & -4.0288 & & & & & & & & & & & & \\
\hline Population growth & & & -0.2246 & -0.3309 & & & & & & & & & & \\
\hline Rural population (\% of total) & & & $-0.2417^{*}$ & 0.0068 & & & & & & & & & & \\
\hline SD M2 growth (yearly) & & & -0.0152 & -0.0171 & & & & & & & & & & \\
\hline SD Inflation (monthly) & & & & & 0.0967 & 0.1150 & & & & & 0.2327 & 0.2049 & & \\
\hline SD M2 growth (monthly) & & & & & & & -0.1767 & -0.1881 & & & & & & \\
\hline SD ER growth (monthly) & & & & & & & & & -0.0437 & 0.0344 & -0.0774 & 0.0138 & & \\
\hline Constant & $8.6926 * * *$ & $* 8.5383 * * *$ & $21.3895 * * *$ & $10.6024 * *$ & *20.2316*** & *16.3554*** & $16.0408 * * *$ & $13.8225^{* * *}$ & $15.8799 * * * 1$ & $11.3434 * * *$ & $18.1225 * * * 1$ & $15.2460 * * * 1$ & $12.0123 *$ & ${ }^{*} 11.3055^{* *}$ \\
\hline $\mathbf{N}$ & 252 & 252 & 252 & 252 & 163 & 163 & 137 & 137 & 177 & 177 & 152 & 152 & 265 & 265 \\
\hline Groups & 41 & 41 & 49 & 49 & 35 & 35 & 33 & 33 & 39 & 39 & 34 & 34 & 54 & 54 \\
\hline $\mathbf{R}^{2}$ & 0.024 & 0.002 & 0.010 & 0.002 & 0.104 & 0.131 & 0.140 & 0.143 & 0.073 & 0.103 & 0.084 & 0.124 & 0.113 & 0.119 \\
\hline AIC & 800.4 & & 776.1 & & 537.7 & & 442.3 & & 551.3 & & 496.3 & & 791.3 & \\
\hline BIC & 860.4 & & 846.7 & & 599.5 & & 500.7 & & 614.8 & & 559.8 & & 852.2 & \\
\hline
\end{tabular}

Notes: The table shows the results of fixed and random effects estimations with robust standard errors where the dependent variable is the unemployment rate. The asterisks indicate whether a coefficient is significantly different from zero at the $10 \%$ (one asterisk), $5 \%$ (two asterisks) or $1 \%$ (three asterisks) significance level. 
Table A.5: Simultaneous Equation Estimations

\begin{tabular}{|c|c|c|c|c|c|c|c|}
\hline Variable & tsls1 & tsls2 & tsls3 & tsls4 & tsls5 & tsls6 & tsls7 \\
\hline \multicolumn{8}{|l|}{ First Stage: } \\
\hline$\overline{\text { Dep. Var. }}$ & real_mthly_gr & hw2wuus & md_hw2wuus & md_hw3wuus & md_hw4wuus & md_hw2wlus & md_hw3wlus \\
\hline CBT & -1.6693 & $-0.9607 * *$ & $-0.7293 *$ & $-0.3752 *$ & $-0.4249 *$ & $-0.7077^{*}$ & -0.3642 \\
\hline $\mathrm{CBT}^{2}$ & & $0.0829 * * *$ & $0.0645^{* *}$ & $0.0283 *$ & $0.0371 * *$ & $0.0630^{* *}$ & $0.0274 *$ \\
\hline CBI & $39.5640 *$ & $2.4177^{*}$ & 1.8923 & 1.6064 & $3.1051 * *$ & 1.8342 & 1.5876 \\
\hline \multicolumn{8}{|l|}{ Second Stage: } \\
\hline $\begin{array}{l}\text { Dep. Var. } \\
\text { Inflation }\end{array}$ & Unemp. & Unemp. & Unemp. & Unemp. & Unemp. & Unemp. & Unemp. \\
\hline Terms of Trade & & $-0.0225 * *$ & $-0.0222 * *$ & $-0.0261 * *$ & $-0.0255^{* * *}$ & $-0.0220^{* *}$ & $-0.0262 * *$ \\
\hline Real Interest Rate & & -0.0374 & -0.0356 & -0.0210 & -0.0207 & -0.0337 & -0.0196 \\
\hline GDP Growth & 0.0121 & -0.0313 & -0.0333 & -0.0043 & -0.0241 & -0.0313 & -0.0006 \\
\hline$(\mathrm{t}-1)$ & $-0.1847 * *$ & $-0.1259 * * *$ & $-0.1274 * * *$ & $-0.0819 *$ & $-0.0948 * *$ & $-0.1284 * * *$ & $-0.0818^{*}$ \\
\hline GDP per Capita & $-0.0006 * * *$ & -0.0004 & -0.0005 & -0.0007 & $-0.0005^{*}$ & -0.0005 & -0.0007 \\
\hline $\begin{array}{l}\text { real_mthly_earnings_gr } \\
\text { hw2wuus }\end{array}$ & 0.0135 & $0.5333^{*}$ & & & & & \\
\hline md_hw2wuus & & & $0.6587^{*}$ & & & & \\
\hline md_hw3wuus & & & & 0.8684 & & & \\
\hline md_hw4wuus & & & & & $0.6062^{*}$ & & \\
\hline md_hw2wlus & & & & & & $0.6666^{*}$ & \\
\hline md_hw3wlus & & & & & & & 0.9033 \\
\hline \multirow{2}{*}{\multicolumn{8}{|c|}{$\begin{array}{l}\text { md_hw4wlus } \\
\text { md mw2wuus }\end{array}$}} \\
\hline \multirow{2}{*}{\multicolumn{8}{|c|}{$\begin{array}{l}\text { md_mw2wuus } \\
\text { md_mw3wuus }\end{array}$}} \\
\hline & & & & & & & \\
\hline \multicolumn{8}{|l|}{ md_mw4wuus } \\
\hline \multirow{2}{*}{\multicolumn{8}{|c|}{$\begin{array}{l}\text { md_mw2wlus } \\
\text { md_mw4wlus }\end{array}$}} \\
\hline & & & & & & & \\
\hline \multicolumn{8}{|l|}{ md_mw3wlus } \\
\hline Constant & $15.3856 * * *$ & $14.0322 * * *$ & $15.2461 * * *$ & $17.0541 * * *$ & $15.4837 * * *$ & $15.5345^{* * *}$ & $17.6030 * * *$ \\
\hline $\mathrm{N}$ & 243 & 164 & 164 & 246 & 246 & 164 & 246 \\
\hline Groups & 51 & 30 & 30 & 41 & 41 & 30 & 41 \\
\hline $\mathrm{R}^{2}$ & 0.10 & 0.27 & 0.27 & 0.21 & 0.22 & 0.27 & 0.21 \\
\hline $\mathrm{Chi}^{2}$ & $7822.47 * * * *$ & $3651.78 * * *$ & $3434.34 * * *$ & $6105.89 * * *$ & $7154.29 * * *$ & $3436.30 * * *$ & $5920.61 * * *$ \\
\hline
\end{tabular}

Notes: The table shows the results of two stages least squares fixed effects estimations where the dependent variable is the unemployment rate and the instrumented variable is the wage. The specific wage measure is mentioned in the table (see Dep. Var.). The other variables of the first stage estimation are not presented. The asterisks indicate whether a coefficient is significantly different from zero at the $10 \%$ (one asterisk), $5 \%$ (two asterisks) or $1 \%$ (three asterisks) significance level. 
Table A.5: Simultaneous Equation Estimations (continued)

\begin{tabular}{|c|c|c|c|c|c|c|c|}
\hline \multirow{2}{*}{\multicolumn{8}{|c|}{$\begin{array}{l}\text { Variable } \\
\text { First Stage: }\end{array}$}} \\
\hline & & & & & & & \\
\hline Dep. Var. & md_hw4wlus & md_mw2wuus & md_mw3wuus & md_mw4wuus & md_mw2wlus & md_mw4wlus & md_mw3wlus \\
\hline CBT & $-0.4208^{*}$ & $-153.4412^{*}$ & -54.7363 & -56.7004 & $-148.2077^{*}$ & -52.6026 & -51.8860 \\
\hline $\mathrm{CBT}^{2}$ & $0.0371^{* *}$ & $13.0420^{* *}$ & $4.5404 *$ & $5.1841^{*}$ & $12.6402 * *$ & $5.0156^{*}$ & $4.3297 *$ \\
\hline CBI & $3.1049 * *$ & 189.2897 & 302.9476 & $614.4949 * *$ & 155.1813 & $577.3718 * *$ & 279.6239 \\
\hline \multicolumn{8}{|l|}{ Second Stage: } \\
\hline $\begin{array}{l}\text { Dep. Var. } \\
\text { Inflation }\end{array}$ & Unemp. & Unemp. & Unemp. & Unemp. & Unemp. & Unemp. & Unemp. \\
\hline Terms of Trade & $-0.0253 * * *$ & $-0.0232 * *$ & $-0.0241 * *$ & $-0.0241 * * *$ & $-0.0229 * *$ & $-0.0241 * * *$ & $-0.0240 * *$ \\
\hline Real Interest Rate & -0.0199 & -0.0322 & -0.0195 & -0.0188 & -0.0323 & -0.0195 & -0.0198 \\
\hline GDP Growth & -0.0243 & -0.0225 & -0.0128 & -0.0280 & -0.0201 & -0.0302 & -0.0097 \\
\hline$(\mathrm{t}-1)$ & $-0.0958 * *$ & $-0.1409^{* * * *}$ & $-0.0874 * *$ & $-0.0976 * * *$ & $-0.1413 * * *$ & $-0.0978 * * *$ & $-0.0862 *$ \\
\hline GDP per Capita & $-0.0005^{*}$ & -0.0005 & -0.0007 & $-0.0006^{*}$ & -0.0005 & $-0.0006^{*}$ & -0.0008 \\
\hline \multicolumn{8}{|l|}{ real_mthly_earnings_gr } \\
\hline \multicolumn{8}{|l|}{$\begin{array}{l}\text { hw2wuus } \\
\text { md hw2wuus }\end{array}$} \\
\hline \multicolumn{8}{|l|}{ md_hw3wuus } \\
\hline \multicolumn{8}{|l|}{$\begin{array}{l}\text { md hw4wuus } \\
\text { ho }\end{array}$} \\
\hline \multicolumn{8}{|l|}{ md_hw2wlus } \\
\hline \multicolumn{8}{|l|}{ md_hw3wlus } \\
\hline md_hw4wlus & $0.6001 *$ & & & & & & \\
\hline md_mw2wuus & & $0.0042 *$ & & & & & \\
\hline md_mw3wuus & & & 0.0052 & & & & \\
\hline md mw4wuus & & & & $0.0038 * *$ & & & \\
\hline md_mw2wlus & & & & & $0.0043 *$ & & \\
\hline md mw4wlus & & & & & & $0.0038 *$ & \\
\hline md_mw3wlus & & & & & & & 0.0054 \\
\hline Constant & $15.4961 * * *$ & $15.6877 * * *$ & $17.6492 * * *$ & $16.8144 * * *$ & $16.0162 * * *$ & $17.0073 * * *$ & $18.1414 * * *$ \\
\hline $\mathrm{N}$ & 246 & 139 & 246 & 246 & 139 & 246 & 246 \\
\hline Groups & 41 & 28 & 41 & 41 & 28 & 41 & 41 \\
\hline $\mathrm{R}^{2}$ & 0.22 & 0.36 & 0.20 & 0.21 & 0.36 & 0.21 & 0.20 \\
\hline $\mathrm{Chi}^{2}$ & $7285.09 * * *$ & $2927.07 * * *$ & $6451.82 * * *$ & $7290.94 * * *$ & $2886.98^{* * * *}$ & $7223.24 * * *$ & $6241.18 * * *$ \\
\hline
\end{tabular}

Notes: The table shows the results of two stages least squares fixed effects estimations where the dependent variable is the unemployment rate and the instrumented variable is the wage. The specific wage measure is mentioned in the table (see Dep. Var.). The other variables of the first stage estimation are not presented. The asterisks indicate whether a coefficient is significantly different from zero at the $10 \%$ (one asterisk), $5 \%$ (two asterisks) or $1 \%$ (three asterisks) significance level. 
Table A.6: Causes of Unemployment Variability

\begin{tabular}{|c|c|c|c|c|c|c|c|c|c|c|c|c|c|c|}
\hline Variable & fe1 & re1 & fe2 & re2 & fe3 & re3 & fe4 & re4 & fe5 & re5 & fe7 & re7 & fe8 & re8 \\
\hline Unemployment & $0.0285^{* * * *}$ & $* 0.0197 * * *$ & $0.0508^{* * * *}$ & $0.0294 * * *$ & $0.0510 * * *$ & $* 0.0323 * * *$ & 0.0035 & $0.0274 * * *$ & $0.0254 * * *$ & $0.0209 * * *$ & $0.0508^{* * * *}$ & $* 0.0294 * * *$ & 0.0168 & $0.0355 * * *$ \\
\hline Real Interest Rate & -0.0001 & -0.0007 & 0.0032 & 0.0037 & 0.0030 & 0.0036 & & & 0.0004 & -0.0004 & 0.0032 & 0.0037 & & \\
\hline CBT (t-1) & -0.0075 & -0.0095 & $-0.0382 *$ & -0.0145 & $-0.0354 *$ & -0.0204 & -0.0284 & $-0.0344 * *$ & -0.0112 & -0.0087 & $-0.0382 *$ & -0.0145 & $-0.0445^{*}$ & $-0.0297 * *$ \\
\hline CBI (t-1) & 0.2743 & 0.1055 & $0.4920^{*}$ & 0.2173 & 0.3998 & 0.2140 & $0.5657^{*}$ & 0.0967 & 0.2537 & 0.1391 & $0.4920^{*}$ & 0.2173 & 0.5447 & -0.0240 \\
\hline SD GDP Growth & & & 0.0081 & 0.0059 & 0.0085 & 0.0052 & & & & & 0.0081 & 0.0059 & & \\
\hline Gross Replacement Rate (2 Year Average) & & & & & & & 0.4579 & -0.3159 & & & & & & \\
\hline Openness & & & & & & & & & $0.0037 * * *$ & $0.0016 * *$ & & & & \\
\hline Minimum Wage & & & & & & & & & & & & & 0.0000 & 0.0000 \\
\hline Constant & $0.2880 * *$ & $0.4414 * * *$ & 0.1335 & $0.3403^{* *}$ & 0.0122 & $0.3023^{*}$ & $0.4985 * *$ & * $0.6249 * * *$ & -0.1547 & $0.2733 * *$ & 0.1335 & $0.3403 * *$ & $0.5034 * *$ & $0.5289 * * *$ \\
\hline $\mathbf{N}$ & 486 & 486 & 305 & 305 & 300 & 300 & 219 & 219 & 481 & 481 & 305 & 305 & 192 & 192 \\
\hline Adj. $\mathbf{R}^{2}$ & -0.070 & & 0.015 & & 0.018 & & -0.194 & & -0.051 & & 0.015 & & -0.147 & \\
\hline $\mathbf{R}^{2}$ & 0.101 & 0.113 & 0.077 & 0.086 & 0.057 & 0.084 & 0.023 & 0.261 & 0.016 & & 0.077 & 0.086 & 0.115 & 0.280 \\
\hline AIC & 183.223 & & 108.570 & & 110.294 & & 41.961 & & 177.467 & & 108.570 & & 15.575 & \\
\hline BIC & 254.388 & & 175.536 & & 180.666 & & 79.241 & & 256.808 & & 175.536 & & 57.923 & \\
\hline$\overline{\overline{\text { CBT_1 }}}$ & 坓-0.0164 & 0.0150 & $\begin{array}{l}-0.0094 \\
\end{array}$ & 0.0254 & 0.0016 & & \begin{tabular}{c|}
-0.0567 \\
\end{tabular} & -0.0230 & (-0.0209 & 0.0169 & $\begin{array}{l}-0.0094 \\
\end{array}$ & 0.0254 & 0.0081 & 0.0335 \\
\hline CBT_2 & 0.0051 & 0.0071 & -0.0110 & 0.0237 & -0.0088 & 0.0177 & -0.0689 & -0.0481 & 0.0035 & 0.0134 & -0.0110 & 0.0237 & -0.0850 & -0.0135 \\
\hline CBT_3 & $-0.1878^{* * * *}$ & $*-0.1411 * * *$ & $-0.2041 * * *$ & $-0.1604 * * *$ & $-0.2013 * * *$ & $*-0.1682 * * *$ & -0.1235 & $-0.1615^{* * *}$ & $-0.1949 * * *$ & $-0.1437 * * *$ & $=-0.2041 * *$ & $*-0.1604 * * *$ & $k_{-}-0.0802$ & $-0.1020 * *$ \\
\hline CBT_4 & -0.0628 & -0.0469 & $-0.1313 * *$ & -0.0680 & $-0.1320 * *$ & $-0.0816^{*}$ & $-0.0968 *$ & $-0.0894 * *$ & -0.0652 & -0.0498 & $-0.1313 * *$ & -0.0680 & -0.0917 & $-0.0801 * *$ \\
\hline CBT 5 & $-0.1309^{* *}$ & $-0.1074 * *$ & $-0.2062^{* * * *}$ & $-0.1443 * * *$ & $-0.2034 * * *$ & $*-0.1614 * * *$ & $-0.1529 * *$ & ${ }^{*}-0.1431^{* * * *}$ & $-0.1163^{* *}$ & $-0.0942 * *$ & $-0.2062 * * *$ & $*_{-}-0.1443 * * *$ & - $0.1808^{* * *}$ & $*_{-} 0.1494 * * *$ \\
\hline
\end{tabular}

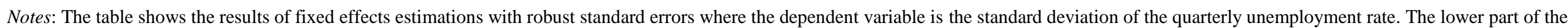

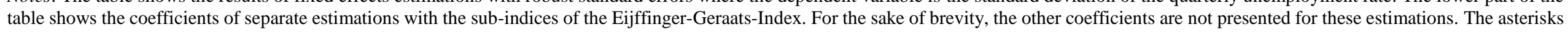
indicate whether a coefficient is significantly different from zero at the $10 \%$ (one asterisk), $5 \%$ (two asterisks) or $1 \%$ (three asterisks) significance level. 
Table A.6: Causes of Unemployment Variability (continued)

\begin{tabular}{|c|c|c|c|c|c|c|c|c|c|c|c|c|c|c|c|c|}
\hline Variable & fe9 & re9 & fe10 & re10 & fe11 & re11 & fe12 & re12 & fe13 & re13 & fe14 & re14 & fe15 & re15 & fe16 & re16 \\
\hline Unemployment & $-0.0251 * *$ & $-0.0251 * *$ & $0.0255^{* * *}$ & $* 0.0190 * * *$ & $0.0237 * * *$ & $* 0.0184 * * *$ & $0.0394 * * *$ & $* 0.0365 * * *$ & $0.0387 * * *$ & $* 0.0377 * * *$ & $0.0382 * * *$ & $0.0399 * * *$ & $0.0373 * * *$ & $0.0387 * * *$ & $0.0299 * *$ & $0.0312 * * *$ \\
\hline Real Interest Rate & & & -0.0002 & -0.0014 & -0.0002 & -0.0012 & 0.0031 & 0.0034 & 0.0043 & 0.0042 & 0.0046 & 0.0051 & 0.0048 & 0.0044 & 0.0108 & 0.0086 \\
\hline CBT (t-1) & $-0.0713 * * *$ & $-0.0713 * * *$ & -0.0132 & -0.0166 & -0.0085 & -0.0122 & -0.0307 & $-0.0246 * *$ & $-0.0398 * *$ & $-0.0206^{*}$ & $-0.0397 * *$ & -0.0166 & $-0.0425 * *$ & -0.0173 & $-0.0570 * *$ & $-0.0289 * *$ \\
\hline CBI (t-1) & $0.5163 * *$ & $0.5163^{* *}$ & 0.3308 & 0.0788 & 0.3316 & 0.0587 & $0.7424 * * *$ & $* 0.3311 * *$ & $0.7886 * * *$ & * $0.3289 * *$ & $0.7928 * * *$ & $0.3827 * * *$ & $0.7635 * * *$ & $0.3393 * *$ & $0.6960^{*}$ & 0.2190 \\
\hline \multirow{2}{*}{\multicolumn{17}{|c|}{$\begin{array}{l}\text { SD GDP Growth } \\
\text { GDP growth }\end{array}$}} \\
\hline \multicolumn{11}{|l|}{ Gross Replacement Rate (2 Year Average) } & & & & & & \\
\hline 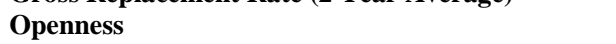 & & & $0.0036^{* *}$ & $0.0011^{*}$ & $0.0033 * *$ & $0.0013^{* *}$ & $0.0031 *$ & $0.0020^{* * * *}$ & $0.0036 * *$ & $0.0017 * * *$ & $0.0036^{* *}$ & $0.0017 * * *$ & $=0.0040 * *$ & $0.0016 * * *$ & $0.0053 *$ & 0.0016 \\
\hline Minimum Wage & & & & & & & & & & & & & & & & \\
\hline Unemployment * CBT $(\mathrm{t}-1)$ & $0.0076^{* * *}$ & $0.0076^{* * * *}$ & & & & & & & & & & & & & & \\
\hline SD Inflation (yearly) & $0.0191 * *$ & $0.0191^{* *}$ & & & & & & & & & & & & & & \\
\hline Labour Market Regulation & & & & & $0.0773 * *$ & -0.0002 & & & & & & & & & & \\
\hline Right of Assocation (Market Sector) & & & & & & & $0.2356^{*}$ & $0.1718^{* *}$ & & & & & & & & \\
\hline Right to Strike (Market Sector) & & & & & & & & & 0.0217 & 0.0460 & & & & & & \\
\hline Right of Collective Bargaining (Market Sector) & & & & & & & & & & & -0.0357 & -0.0722 & & & & \\
\hline Right of Collective Bargaining Government Sector) & & & & & & & & & & & & & $-0.1543 *$ & -0.0258 & & \\
\hline Social Pact (Employment Policies) & & & & & & & & & & & & & & & -0.0421 & -0.0625 \\
\hline Constant & $0.5944 * * *$ & $0.5944 * * *$ & $-0.6167 *$ & 0.0048 & -0.4795 & 0.2845 & $-0.7301 *$ & -0.3173 & -0.1447 & 0.0315 & -0.0034 & 0.2657 & 0.1315 & 0.1571 & -0.1275 & 0.1384 \\
\hline$\overline{\mathbf{N}}$ & 446 & 446 & 446 & 446 & 441 & 441 & 309 & 309 & 309 & 309 & 309 & 309 & 309 & 309 & 217 & 217 \\
\hline Groups & 40 & 40 & 43 & 43 & 43 & 43 & 27 & 27 & 27 & 27 & 27 & 27 & 27 & 27 & 19 & 19 \\
\hline Adj. $\mathbf{R}^{2}$ & -0.048 & -0.048 & -0.074 & & -0.075 & & 0.033 & & 0.020 & & 0.020 & & 0.033 & & -0.018 & \\
\hline $\mathbf{R}^{2}$ & 0.085 & 0.085 & 0.094 & 0.139 & 0.062 & 0.139 & 0.329 & 0.366 & 0.286 & 0.354 & 0.281 & 0.358 & 0.241 & 0.348 & 0.313 & 0.407 \\
\hline BIC & 241.941 & 241.941 & 251.239 & & 251.482 & & 162.716 & & 166.918 & & 166.820 & & 162.501 & & 142.315 & \\
\hline 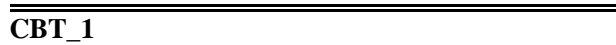 & -0.0784 & -0.0784 & -0.0769 & 0.0062 & -0.0591 & 0.0148 & $\begin{array}{l}-0.0131 \\
\end{array}$ & 0.0041 & 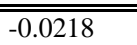 & 0.0267 & -0.0249 & 0.0439 & -0.0331 & 0.0334 & -0.1228 & -0.0549 \\
\hline CBT_2 & $-0.2297 * * *$ & $-0.2297 * * *$ & $k^{*}-0.0021$ & -0.0139 & -0.0046 & -0.0125 & 0.0458 & -0.0067 & 0.0124 & -0.0032 & 0.0080 & -0.0084 & -0.0001 & 0.0036 & 0.0057 & -0.0399 \\
\hline CBT_3 & -0.1399 & -0.1399 & $-0.2295 * * *$ & *-0.1584*** & $-0.2114 * * *$ & $*-0.1441 * * *$ & $-0.2041 * * *$ & $*-0.1281 * * *$ & $-0.2244 * * *$ & $*-0.1320 * * *$ & $-0.2254 * * *$ & $k-0.1098 * * *$ & $-0.2379 * * *$ & $*-0.1153 * * *$ & $-0.2664 * * *$ & $-0.1087 * *$ \\
\hline CBT_4 & $-0.1393 * *$ & $-0.1393 * *$ & -0.0732 & $-0.0655^{*}$ & -0.0722 & $-0.0609^{*}$ & $-0.1375^{* * *}$ & $*-0.0913 * *$ & $-0.1484 * * *$ & ${ }^{*}-0.0846 * *$ & $-0.1499 * * *$ & ${ }^{*}-0.0806 * *$ & $-0.1424 * * *$ & $*-0.0821 * *$ & $-0.1383 * *$ & $-0.0812 * *$ \\
\hline CBT_5 & $-0.2715 * * *$ & $-0.2715^{* * * *}$ & $-0.1327 * *$ & $-0.1031 * *$ & $-0.1223^{*}$ & $-0.1009 * *$ & $-0.1464 * *$ & $-0.1230 * * *$ & $=-0.1496 * *$ & $-0.1130 * *$ & $-0.1451^{*}$ & $-0.0906 *$ & -0.1191 & $-0.0975 * *$ & $-0.2426^{* *}$ & $-0.1113 * *$ \\
\hline
\end{tabular}

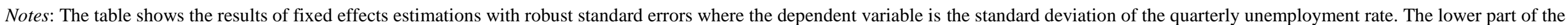

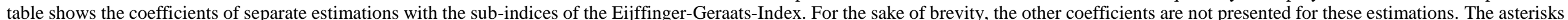
indicate whether a coefficient is significantly different from zero at the $10 \%$ (one asterisk), $5 \%$ (two asterisks) or $1 \%$ (three asterisks) significance level. 
Table A.6: Causes of Unemployment Variability (continued)

\begin{tabular}{|c|c|c|c|c|c|c|c|c|c|c|c|c|}
\hline Variable & fe17 & re17 & fe18 & re18 & fe19 & re19 & fe20 & re20 & fe21 & re21 & fe22 & re22 \\
\hline Unemployment & $0.0399 * * *$ & $0.0349 * * *$ & ${ }^{*} 0.0382$ *** & $0.0366^{* * * *}$ & 0.0090 & $0.0127 * *$ & 0.0230 & 0.0394 *** & * 0.0119 & $0.0342 * * *$ & $* 0.0115$ & $0.0307^{* * * *}$ \\
\hline Real Interest Rate & 0.0075 & 0.0063 & 0.0083 & 0.0044 & -0.0053 & -0.0060 & 0.0064 & 0.0001 & -0.0047 & -0.0074 & -0.0053 & -0.0074 \\
\hline CBT (t-1) & $-0.0410 * *$ & $-0.0261 * *$ & $-0.0400^{*}$ & $-0.0238^{* * *}$ & $-0.0328 *$ & $-0.0361^{* * * *}$ & ${ }^{*}-0.0475 *$ & $-0.0309 * *$ & -0.0352 & $-0.0326 * *$ & -0.0349 & $-0.0332 * *$ \\
\hline CBI (t-1) & $0.6373 * * *$ & $0.3994 * *$ & $0.6442 * * *$ & $0.3507 * *$ & $0.3910 *$ & 0.0620 & 0.2816 & -0.2999 & 0.3763 & -0.0756 & 0.3596 & -0.1261 \\
\hline Openness & 0.0039 & 0.0007 & $0.0041^{*}$ & 0.0006 & 0.0007 & 0.0008 & 0.0090 *** & 0.0008 & 0.0005 & 0.0006 & 0.0011 & 0.0006 \\
\hline Minimum Wage & & & & & & & 0.0000 & 0.0000 & & & & \\
\hline Union Density & -0.0048 & 0.0002 & 0.0012 & -0.0073 & & & & & & & & \\
\hline Union Density² & & & -0.0001 & 0.0001 & & & & & & & & \\
\hline Civil Liberties & & & & & -0.0588 & $-0.0659 * *$ & & & & & & \\
\hline Gross Replacement Rate (1st Year) & & & & & & & & & 0.5166 & -0.1854 & & \\
\hline Gross Replacement Rate (2nd Year) & & & & & & & & & & & -0.1783 & -0.4859 \\
\hline Constant & 0.1386 & 0.2104 & 0.0178 & $0.3396^{*}$ & $0.6862 * *$ & $* 0.8070 * * *$ & $*-0.1056$ & $0.5599 * * *$ & * 0.4448 & $0.6163^{* * *}$ & $* 0.5505$ & $0.6483 * * *$ \\
\hline $\mathbf{N}$ & 197 & 197 & 197 & 197 & 363 & 363 & 178 & 178 & 202 & 202 & 202 & 202 \\
\hline Groups & 17 & 17 & 17 & 17 & 44 & 44 & 29 & 29 & 32 & 32 & 32 & 32 \\
\hline Adj. $\mathbf{R}^{2}$ & 0.102 & & 0.098 & & -0.110 & & -0.086 & & -0.190 & & -0.196 & \\
\hline $\mathbf{R}^{2}$ & 0.314 & 0.396 & 0.301 & 0.427 & 0.104 & 0.182 & 0.038 & 0.312 & 0.076 & 0.331 & 0.142 & 0.331 \\
\hline AIC & -22.800 & & -21.086 & & 53.448 & & -3.666 & & 29.484 & & 30.449 & \\
\hline BIC & 39.581 & & 44.578 & & 115.759 & & 44.061 & & 72.491 & & 73.456 & \\
\hline$\overline{\text { CBT_1 }}$ & 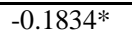 & $\begin{array}{l}-0.0734 \\
\end{array}$ & -0.1834* & 0.0522 & 0.0053 & 0.0272 & $\begin{array}{c}0.1347 \\
\end{array}$ & 0.0698 & $\begin{array}{c}0.0107 \\
\end{array}$ & 0.0262 & $\begin{array}{c}-0.0118 \\
\end{array}$ & 0.0186 \\
\hline CBT_2 & 0.0034 & -0.0072 & 0.0065 & -0.0156 & -0.0375 & -0.0431 & $-0.1316^{*}$ & -0.0492 & $-0.1084 *$ & -0.0719 & $-0.1168^{*}$ & -0.0747 \\
\hline CBT_3 & $-0.1652^{*}$ & $-0.0890 * *$ & $-0.1723^{*}$ & $-0.0824 * *$ & $-0.1916^{* * *}$ & $*-0.1729 * * *$ & $*-0.0965$ & $-0.1049 * *$ & $-0.1394 *$ & $*-0.1569 * * *$ & ${ }^{*}-0.1419$ ** & $*-0.1557 * * *$ \\
\hline CBT_4 & -0.0952 & $-0.0717 *$ & -0.0959 & -0.0610 & -0.0642 & $-0.0711 * *$ & -0.0866 & $-0.0764 *$ & $-0.1248^{*}$ & $*-0.0941 * *$ & -0.1217 ** & $*-0.0931 * *$ \\
\hline CBT_5 & -0.1300 & $-0.1338^{* * * *}$ & ${ }^{k}-0.1341$ & $-0.0983^{*}$ & -0.1763 ** & $*-0.1406 * * *$ & $*-0.1595 * *$ & $-0.1456^{* * *}$ & $-0.1576^{*}$ & $*-0.1298^{* *}$ & -0.1654 ** & $*-0.1381 * *$ \\
\hline
\end{tabular}

Notes: The table shows the results of fixed effects estimations with robust standard errors where the dependent variable is the standard deviation of the quarterly unemployment rate. The lower part of the table shows the coefficients of separate estimations with the sub-indices of the Eijffinger-Geraats-Index. For the sake of brevity, the other coefficients are not presented for these estimations. The asterisks indicate whether a coefficient is significantly different from zero at the $10 \%$ (one asterisk), $5 \%$ (two asterisks) or $1 \%$ (three asterisks) significance level. 
Table A.6: Causes of Unemployment Variability (continued)

\begin{tabular}{|c|c|c|c|c|c|c|c|c|c|c|}
\hline Variable & fe23 & re23 & fe24 & re24 & fe25 & re25 & fe26 & re26 & fe27 & re27 \\
\hline Unemployment & 0.0122 & $0.0336^{* * * *}$ & $* 0.0138$ & $0.0285^{* * * *}$ & $0.0298^{* *}$ & $0.0378^{* * * *}$ & $0.0270 * *$ & $0.0302 * * *$ & $0.0385^{* * *}$ & $0.0220^{* * * *}$ \\
\hline Real Interest Rate & -0.0045 & -0.0079 & 0.0009 & -0.0028 & -0.0069 & -0.0044 & $0.0116 *$ & 0.0085 & 0.0005 & 0.0010 \\
\hline CBT (t-1) & -0.0356 & $-0.0320 * *$ & -0.0313 & -0.0235 & -0.0311 & -0.0188 & -0.0327 & $-0.0231 * *$ & $-0.0355^{*}$ & $-0.0137 *$ \\
\hline CBI (t-1) & 0.4088 & -0.0975 & 0.4736 & -0.0740 & $0.6109 * *$ & $0.3097 * *$ & $0.7356^{*}$ & $0.2231 *$ & 0.3012 & 0.0445 \\
\hline Gross Replacement Rate (2 Year Average & 0.5037 & -0.4211 & & & & & & & & \\
\hline Openness & 0.0006 & 0.0005 & 0.0023 & 0.0007 & -0.0003 & $0.0014 * * *$ & 0.0001 & $0.0016^{* * *}$ & $0.0071 * * *$ & 0.0000 \\
\hline Unemployment Benefits Coverage & & & -0.2437 & -0.2742 & & & & & & \\
\hline Union Density (2) & & & & & 0.0033 & -0.0010 & & & & \\
\hline Union Density ${ }^{2}(2)$ & & & & & 0.0000 & 0.0000 & & & & \\
\hline Coordination & & & & & & & 0.0791 & -0.0410 & & \\
\hline Left-Winged & & & & & & & & & $-0.1054 * *$ & $-0.0838 * *$ \\
\hline Constant & 0.4724 & $0.6518^{* * * *}$ & ${ }^{*} 0.3988$ & $0.6191 * * *$ & 0.3615 & $0.2939^{*}$ & -0.0223 & 0.2532 & -0.0891 & $0.4493 * * *$ \\
\hline $\mathbf{N}$ & 202 & 202 & 191 & 191 & 257 & 257 & 238 & 238 & 338 & 338 \\
\hline Groups & 32 & 32 & 31 & 31 & 29 & 29 & 21 & 21 & 35 & 35 \\
\hline Adj. $\mathbf{R}^{2}$ & -0.194 & & -0.194 & & -0.063 & & -0.041 & & -0.016 & \\
\hline $\mathbf{R}^{2}$ & 0.090 & 0.339 & 0.145 & 0.304 & 0.164 & 0.366 & 0.191 & 0.414 & 0.115 & 0.180 \\
\hline AIC & 30.139 & & 24.985 & & 43.031 & & 91.587 & & 76.885 & \\
\hline BIC & 73.147 & & 67.265 & & 110.463 & & 157.560 & & 149.523 & \\
\hline$\overline{\text { CBT_1 }}$ & 0.0305 & 0.0201 & "0.0833 & 0.0693 & -0.0142 & 0.0466 & -0.0387 & 0.0052 & -0.0068 & 0.0444 \\
\hline CBT_2 & $-0.1211^{*}$ & -0.0710 & $-0.1124 *$ & -0.0598 & 0.0566 & 0.0123 & 0.0618 & -0.0185 & -0.0717 & -0.0305 \\
\hline CBT_3 & $-0.1420 * *$ & ${ }^{*}-0.1553 * * *$ & -0.1236 & $-0.1311 * * *$ & $-0.1959 * * *$ & $-0.1095 * *$ & $-0.1811 * *$ & $-0.0880 * *$ & $-0.2512 * *$ & - $0.0737 * * *$ \\
\hline CBT_4 & $-0.1290 * *$ & ${ }^{*}-0.0920 * *$ & $-0.1030^{*}$ & $-0.0727 *$ & $-0.1416^{* * *}$ & $-0.1099 * * *$ & $-0.1735 * *$ & $*-0.1077 * * *$ & -0.0651 & -0.0256 \\
\hline CBT_5 & $-0.1592 * *$ & ${ }^{*}-0.1305^{* * *}$ & $-0.1549 * *$ & k-0.1107* & -0.1094 & $-0.1017 * *$ & -0.1424 & $-0.0846^{*}$ & $-0.2254 * * *$ & ${ }^{*}-0.0537$ \\
\hline
\end{tabular}

Notes: The table shows the results of fixed effects estimations with robust standard errors where the dependent variable is the standard deviation of the quarterly unemployment rate. The lower part of the table shows the coefficients of separate estimations with the sub-indices of the Eijffinger-Geraats-Index. For the sake of brevity, the other coefficients are not presented for these estimations. The asterisks indicate whether a coefficient is significantly different from zero at the $10 \%$ (one asterisk), $5 \%$ (two asterisks) or $1 \%$ (three asterisks) significance level. 
Table A.7: Descriptive Statistics

\begin{tabular}{ll} 
Variable & Data Source \\
\hline TI & Dincer and Eichengreen (2014) \\
TI & Dincer and Eichengreen (2014) \\
CBT_1 & Dincer and Eichengreen (2014) \\
CBT_2 & Dincer and Eichengreen (2014) \\
CBT_3 & Dincer and Eichengreen (2014) \\
CBT_4 & Dincer and Eichengreen (2014) \\
CBT_5 & Dincer and Eichengreen (2014) \\
CBI & Dincer and Eichengreen (2014) \\
Money growth & World Development Indicators \\
Broad money to total reserves & World Development Indicators \\
Exports (\% of GDP) & World Development Indicators \\
GDP growth & World Development Indicators \\
GDP per capita (US \$) & World Development Indicators \\
GDP per capita (LCU) & World Development Indicators \\
Gross savings (\% of GDP) & World Development Indicators \\
Imports (\% of GDP) & World Development Indicators \\
Inflation (CPI) & World Development Indicators \\
Inflation (GDP deflator) & World Development Indicators \\
Long-term unemployment (\% of total unemployment) & World Development Indicators \\
Money and quasi money growth & World Development Indicators \\
Terms of trade & World Development Indicators \\
Net taxes on products & World Development Indicators \\
Exchange rate (LCU per US\$) & World Development Indicators \\
Population growth & World Development Indicators \\
Profit tax & World Development Indicators \\
Real effective exchange rate & World Development Indicators \\
Real interest rate & World Development Indicators \\
Rural population & World Development Indicators \\
Self-employed (\% of total employment) & World Development Indicators \\
Tariff rate (mean) & World Development Indicators \\
Trade (\% of GDP) & World Development Indicators \\
Unemployment & World Development Indicators \\
Log(unemployment) & World Development Indicators \\
Civil liberties & Freedom House \\
Right of Association, market sector & Visser (2015) \\
Right of Association, government & Visser (2015) \\
Right of Collective bargaining, market sector & Visser (2015) \\
Right of Collective bargaining, government sector & Visser (2015) \\
Right to Strike, market sector & Visser (2015) \\
& \\
\hline
\end{tabular}

and Eichengreen (2014)

Dincer and Eichengreen (2014)

chengreen (2014)

Dincer and Eichengreen (2014)

World Development Indicators

World Development Indicators

Devers

Worlopment Indicators

World Development Indicators

World Development Indicators

World Development Indicators

World Development Indicators

Development Indicators

World Development Indicators

Development Indicators

evelopment Indicators

World Development Indicators

Visser (2015)
Observation

\begin{tabular}{rrrrrr} 
Observations & Mean & Std. Dev. & Minimum & \multicolumn{2}{c}{ Maximum } \\
1,506 & 4.702523 & 3.047872 & 0 & 14.5 \\
1,506 & 31.39708 & 38.43494 & 0 & 210.25 \\
1,188 & 1.992003 & 0.7748544 & 0 & 3 \\
1,188 & 0.7424242 & 0.8415704 & 0 & 3 \\
1,188 & 0.8059764 & 0.7371634 & 0 & 3 \\
1,188 & 0.6334175 & 0.8184392 & 0 & 3 \\
1,188 & 0.7213805 & 0.7021911 & 0 & 3 \\
1,075 & 0.4497516 & 0.20851 & 0.09 & 0.893 \\
2,745 & 16.48713 & 21.46785 & -64.69777 & 528.1943 \\
2,709 & 6.020586 & 19.56991 & 0.1947188 & 512.1625 \\
3,071 & 41.8974 & 28.43836 & 0.1829688 & 230.269 \\
3,281 & 3.942103 & 5.515328 & -62.07592 & 104.4868 \\
3,261 & 11293.06 & 17950.83 & 129.7822 & 158602.5 \\
3,294 & 779049.6 & 3096281 & 126.3278 & $3.37 \mathrm{E}+07$ \\
2,433 & 21.45069 & 17.20039 & -22.10914 & 342.1523 \\
3,071 & 48.57127 & 27.98702 & 0.1248936 & 415.79 \\
2,923 & 7.039486 & 18.5019 & -18.10863 & 513.9069 \\
3,277 & 8.363558 & 49.65127 & -31.56591 & 2630.123 \\
844 & 33.64929 & 19.27121 & 0 & 90.5 \\
2,955 & 15.94304 & 23.65084 & -77.51516 & 528.1943 \\
2,939 & 108.4011 & 32.71257 & 21.21808 & 262.0892 \\
2,376 & $1.73 \mathrm{E}+12$ & $1.28 \mathrm{E}+13$ & $-3.62 \mathrm{E}+12$ & $2.14 \mathrm{E}+14$ \\
3,013 & 656.2696 & 2461.962 & 0.023706 & 25941.66 \\
3,633 & 1.433671 & 1.569449 & -10.95515 & 17.62477 \\
527 & 16.03454 & 9.826014 & 0 & 65.8 \\
1,598 & 99.40624 & 28.13532 & 47.17417 & 827.245 \\
2,411 & 7.296087 & 11.93626 & -72.55505 & 252.1153 \\
3,604 & $1.56 \mathrm{E}+07$ & $7.62 \mathrm{E}+07$ & 0 & $8.76 \mathrm{E}+08$ \\
1,457 & 29.83377 & 20.12086 & 0.5 & 94.7 \\
1,811 & 8.253181 & 6.215368 & 0 & 47.92 \\
3,071 & 90.46867 & 52.24783 & 0.3088029 & 531.7374 \\
2,784 & 8.749928 & 6.162116 & 0 & 38.6 \\
2,783 & 1.938627 & 0.7209705 & -1.609438 & 3.653252 \\
2,417 & 3.340091 & 1.812444 & 1 & 7 \\
669 & 2.866966 & 0.3929772 & 1 & 3 \\
669 & 2.431988 & 0.6922966 & 0 & 3 \\
669 & 2.718984 & 0.4757108 & 1 & 3 \\
669 & 1.717489 & 1.008649 & 0 & 3 \\
669 & 2.496263 & 0.6580236 & 0 & \\
& & & & \\
& & & 0
\end{tabular}

Minimum Maximum 
Right to Strike, government

coordination of wage-setting

Type of coordination of wage setting

government intervention in wage bargaining

level(s) at which wage bargaining takes place

Articulation of sectoral bargaining

Opening clauses

Mandatory extension of collective agreements by public law

Length of collective (wage) agreements

National Minimum Wage

Minimum Wage Setting

A social pact is (publicly) being proposed by the government

A (tripartite) social pact between the government

Agreement signed in specified year

agreement is autonomously negotiated (non-wage issues)

agreement is negotiated (wages)

agreement is autonomously negotiated (wages)

Pact or agreement is negotiated by all or some of the (possible) actors

Scope of social pact

Type of social pact

pact or agreement is about wage issues

pact or agreement is about non-wage issues

status of works council

structure of works council representation

rights of works councils

involvement of works councils (or similar structures) in wage negotiations sectoral organization of employment relations

Main confederation(s) represent(s) the affiliates politically

confederal (political) control over appointment of leaders of affiliates

confederal involvement in wage agreements negotiated by its affiliate union

confederal or joint strike fund from which member unions are reimbursed

confederal power over strikes by affiliates

authority of confederation over its affiliates

union (affiliate) role in wage bargaining

union (affiliate) control over appointment of workplace representatives

union (affiliate) finances

union (affiliate) strike fund

union (affiliate) power over enterprise strikes

authority of union (affiliate) over their local or workplace branches and representatives

Number of Employers' Confederations (Organisations)

Employers' organisation density

Number of Union Confederations
Visser (2015)

Visser (2015)

Visser (2015)

Visser (2015)

Visser (2015)

Visser (2015)

Visser (2015)

Visser (2015)

Visser (2015)

Visser (2015)

Visser (2015)

Visser (2015)

Visser (2015)

Visser (2015)

Visser (2015)

Visser (2015)

Visser (2015)

Visser (2015)

Visser (2015)

Visser (2015)

Visser (2015)

Visser (2015)

Visser (2015)

Visser (2015)

Visser (2015)

Visser (2015)

Visser (2015)

Visser (2015)

Visser (2015)

Visser (2015)

Visser (2015)

Visser (2015)

Visser (2015)

Visser (2015)

Visser (2015)

Visser (2015)

Visser (2015)

Visser (2015)

Visser (2015)

Visser (2015)

Visser (2015)

Visser (2015) $\begin{array}{lll}669 & 1.15994 & 0.9268826\end{array}$

$\begin{array}{lll}572 & 2.63986 & 1.204059\end{array}$

$\begin{array}{lrr}448 & 2.176339 & 1.552273\end{array}$

2.7184

$636 \quad 2.105346$

$\begin{array}{lll}461 & 2.219089 & 2.057527\end{array}$

$\begin{array}{lll}475 & 1.985263 & 1.920848\end{array}$

$\begin{array}{lll}582 & 1.245704 & 1.174796\end{array}$

$\begin{array}{lll}419 & 1.649224 & 0.7679873\end{array}$

$\begin{array}{lll}639 & 1.416275 & 0.8259797\end{array}$

$\begin{array}{lll}639 & 5.208138 & 2.743278\end{array}$

$\begin{array}{lll}519 & 0.132948 & 0.3510233\end{array}$

$\begin{array}{lll}519 & 0.0963391 & 0.3018062\end{array}$

$\begin{array}{lll}518 & 0.1293436 & 0.3472299\end{array}$

$\begin{array}{lll}514 & 0.0175097 & 0.1312885\end{array}$

$\begin{array}{lll}514 & 0.0214008 & 0.1448572\end{array}$

$\begin{array}{lll}514 & 0.0622568 & 0.2418568\end{array}$

$\begin{array}{lll}518 & 0.0289575 & 0.1895002\end{array}$

$\begin{array}{lll}519 & 0.1445087 & 0.4735511\end{array}$

$\begin{array}{lll}519 & 0.1984586 & 0.6584156\end{array}$

$\begin{array}{lll}519 & 0.0751445 & 0.2638787\end{array}$

$\begin{array}{lll}514 & 0.0719844 & 0.2587139\end{array}$

$\begin{array}{lll}486 & 1.271605 & 0.8175247\end{array}$

$\begin{array}{lll}487 & 2.090349 & 1.40986\end{array}$

$\begin{array}{lll}487 & 1.297741 & 0.9513122\end{array}$

$\begin{array}{lll}487 & 0.9876797 & 1.004031\end{array}$

$\begin{array}{lll}487 & 0.9158111 & 0.8432109\end{array}$

$\begin{array}{lll}539 & 1.179963 & 0.6560323\end{array}$

$\begin{array}{lll}539 & 0.5565863 & 0.5436762\end{array}$

$\begin{array}{lll}539 & 0.7717996 & 0.5383635\end{array}$

$\begin{array}{lll}539 & 0.5194805 & 0.6885217\end{array}$

$\begin{array}{lll}539 & 0.4174397 & 0.6468052\end{array}$

$\begin{array}{llll}539 & 0.3445269 & 0.1909493\end{array}$

$\begin{array}{lll}539 & 0.5825603 & 0.5228533\end{array}$

$\begin{array}{llll}539 & 0.3116883 & 0.6007065\end{array}$

$\begin{array}{lll}539 & 1.309833 & 0.5642014\end{array}$

$\begin{array}{lll}539 & 0.6716141 & 0.8302771\end{array}$

$\begin{array}{lll}539 & 0.5621521 & 0.7500532\end{array}$

$\begin{array}{lll}537 & 0.3443203 & 0.1905911\end{array}$

$\begin{array}{lrr}422 & 3.554502 & 2.413465\end{array}$

$\begin{array}{lll}91 & 66.84172 & 27.32856\end{array}$

$479 \quad 3.167015 \quad 1.801115$ 
Effective Number of Union Confederations

Number of affiliates of confederation 1 (usually largest)

Effective number of affiliates of confederation 1

Total membership of unions affiliated to confederation 1 (usually largest)

Number of affiliates of confederation 2

Total membership of unions affiliated to confederation 2

Number of affiliates of confederation 3

Total membership of unions affiliated to confederation 3

Number of affiliates of confederation 4

Total membership of unions affiliated to confederation 4

Number of affiliates of confederation 5

Total membership of unions affiliated to confederation 5

Number of affiliates of confederation 6

Total membership of unions affiliated to confederation 6

Number of affiliates of confederation 7

Total membership of unions affiliated to confederation 7

Number of affiliates of confederation 8

Total membership of unions affiliated to confederation 8

Number of Independent (Not-affiliated) Unions

Membership of Independent Unions

Total Number of Unions

Total Union Membership

Net Union Membership

Union Membership as based on (national) household of labour forcer suvey

Wage and Salary Earners in Employment

Union density rate

Union density date (labour survey)

Union coverage of workplaces or establishments

Bargaining (or Union) Coverage, adjusted

Bargaining (or Union) Coverage, private or market sector

Bargaining (or Union) Coverage, public or government sector

Membership share of Confederation 1

Membership share of Confederation 2

Membership share of Confederation 3

Membership share of Confederation 4

Membership share of Confederation 5

Membership share of Confederation 6

Membership share of Confederation 7

Membership share of Confederation 8

External demarcations between union confederations

Internal demarcations within union confederations

Membership concentration at central or confederal level

Membership concentration at the industry level
Visser (2015)

Visser (2015)

Visser (2015)

Visser (2015)

Visser (2015)

Visser (2015)

Visser (2015)

Visser (2015)

Visser (2015)

Visser (2015)

Visser (2015)

Visser (2015)

Visser (2015)

Visser (2015)

Visser (2015)

Visser (2015)

Visser (2015)

Visser (2015)

Visser (2015)

Visser (2015)

Visser (2015)

Visser (2015)

Visser (2015)

Visser (2015)

Visser (2015)

Visser (2015)

Visser (2015)

Visser (2015)

Visser (2015)

Visser (2015)

Visser (2015)

Visser (2015)

Visser (2015)

Visser (2015)

Visser (2015)

Visser (2015)

Visser (2015)

Visser (2015)

Visser (2015)

Visser (2015)

Visser (2015)

Visser (2015)

Visser (2015) $\begin{array}{ll}315 & 2.529128\end{array}$

$232 \quad 13810.26$

$\begin{array}{ll}285 & 9.158236\end{array}$

$391 \quad 4475.68$

$112 \quad 31.21429$

$252 \quad 1228.553$

$86 \quad 14.37209$

$\begin{array}{rr}209 & 368.0077\end{array}$

$\begin{array}{ll}59 & 17.54915\end{array}$

$143 \quad 232.2591$

\begin{tabular}{ll}
$31 \quad 26.06452$ \\
\hline
\end{tabular}

$17 \quad 229.512$

$\begin{array}{lr}22 & 26.31818\end{array}$

$\begin{array}{rr}68 & 101.849 \\ 10 & 4.5\end{array}$

$\begin{array}{rr}10 & 4.5 \\ 47 & 170.7592\end{array}$

4

$\begin{array}{ll}19 & 66.43984\end{array}$

$62 \quad 36.95161$

$\begin{array}{ll}240 & 288.4231\end{array}$

$128 \quad 170.6727$

$424 \quad 5228.81$

$497 \quad 4492.9$

$\begin{array}{ll}111 & 4723.835\end{array}$

$\begin{array}{ll}625 & 14451.5\end{array}$

$\begin{array}{ll}489 & 32.42131\end{array}$

$\begin{array}{ll}166 & 30.73729\end{array}$

$\begin{array}{ll}35 & 36.70205\end{array}$

$254 \quad 49.47147$

$111 \quad 53.47995$

$93 \quad 82.81935$
363

$\begin{array}{lll}363 & 0.6315236\end{array}$

$\begin{array}{lll}255 & 0.2269347\end{array}$

$200 \quad 0.09328$

1340.0985178

$\begin{array}{ll}09 & 0.0654422\end{array}$

$\begin{array}{lll}45 & 0.0778641\end{array}$

50.0587748

$338 \quad 1.315089$

$\begin{array}{lll}335 & 0.5122909\end{array}$

3390.1376047

1.5
89
9.3

0.3600735

0.2425022

0.112621
1.577409

113183.8

.675679

79.97944

3979.324

26.08766

23.94738

308.4113

0.97315

579.2425

55.1866

1.269296

296.9329

22.86514

48.71006

548.6963

824.7801

8078.52

4596.801

27265.71

21.05559

19.53222

29.0207

32.39015

23.56811

0.2230828
0.1717028

0.0645362

0.0946027

0.0694909

0.0743545

0.0979429
9.033844

1324000

25.64103

226300

839

34800

238
5.732

5745.732
150

150
2600
289

6000

260

378.087

7

1500
20

80

278

3468

9374

226300

$41.958-226300$

$481.425 \quad 16476.7$

$115.3662 \quad 287913$

$\begin{array}{ll}5.797465 & 99.06912\end{array}$

81.30803

55.2

100

100

29.1

0.02

0

0

0.0015625

0.0001454

0.2535088

0.2184161

0.2321429

0.1106948

0.039 
Summary measure of formal authority of unions

Summary measure of concentration of unions at peak and sectoral level

Summary measure of centralisation of wage bargaining

Percentage share of females in total membership

Union density rate of females

Union density rate of males

Percentage share of part-time workers in total membership

Union density rate of part-time workers

Union density rate of fulltime workers

Percentage share of temporary workers

Union density rate of temporary workers

Union density rate of permanent workers

Percentage share of manual workers in total membership

Union density rate of manual (blue-collar) workers

Union density rate of non-manual (white-collar) workers

Percentage share of skilled worker in total membership

Union density rate of skilled workers

Union density rate of unskilled worker

Percentage share of public sector* workers in total membership

Employment Protection

Union density

Wage growth

SD Exchange Rate Growth (monthly)

SD Exchange Rate Growth (yearly)

SD Inflation (monthly)

SD Inflation (yearly)

Minimum wage data in original units, National currency

Mean wage data in original units, National currency

Monthly minimum wage, National currency

Ratio of minimum wage to mean wage (see notes on coding below)

Median wage

Ratio of minimum wage to median wage

Year of first law introducing unemployment benefits legislation

Gross Replacement Rate, year 1

Gross Replacement Rate, year 2

Gross Replacement Rate, average over 2 years

Unemployment Benefits Coverage

Advance Notice (maximum, in months)

Advance Notice Period after 9 months, in months

OECD Score for Advance Notice after 9 months

Advance Notice Period after 4 years, in months

OECD Score for Advance Notice after 4 years

Advance Notice Period after 20 years, in months
Visser (2015)

Visser (2015)

Visser (2015)

Visser (2015)

Visser (2015)

Visser (2015)

Visser (2015)

Visser (2015)

Visser (2015)

Visser (2015)

Visser (2015)

Visser (2015)

Visser (2015)

Visser (2015)

Visser (2015)

Visser (2015)

Visser (2015)

Visser (2015)

Visser (2015)

OECD

OECD

OECD

IMF

IMF

IMF

Aleksynska and Schindler (2011)

Aleksynska and Schindler (2011)

Aleksynska and Schindler (2011)

Aleksynska and Schindler (2011)

Aleksynska and Schindler (2011)

Aleksynska and Schindler (2011)

Aleksynska and Schindler (2011)

Aleksynska and Schindler (2011)

Aleksynska and Schindler (2011)

Aleksynska and Schindler (2011)

Aleksynska and Schindler (2011)

Aleksynska and Schindler (2011)

Aleksynska and Schindler (2011)

Aleksynska and Schindler (2011)

Aleksynska and Schindler (2011)

Aleksynska and Schindler (2011)

Aleksynska and Schindler (2011)
3390.3784661

$\begin{array}{lll}334 & 0.3253682\end{array}$

$\begin{array}{lll}333 & 0.3899402\end{array}$

$\begin{array}{ll}114 & 43.42597\end{array}$

$127 \quad 31.21533$

$\begin{array}{lll}41 & 20.10173 & 7.785091\end{array}$

$\begin{array}{lll}57 & 15.36378 & 6.405776\end{array}$

$\begin{array}{lll}56 & 24.96694 & 8.271587\end{array}$

$\begin{array}{llll}20 & 7.745697 & 4.98222\end{array}$

$\begin{array}{lll}25 & 12.53104 & 6.773808\end{array}$

$\begin{array}{rrr}21 & 12.53104 & 6.773808 \\ 21 & 25.3619 & 4.707067\end{array}$

$\begin{array}{lll}12 & 32.96189 & 12.20296\end{array}$

$\begin{array}{lll}13 & 26.82698 & 9.040868\end{array}$

$\begin{array}{lll}13 & 24.28846 & 11.56626\end{array}$

$18 \quad 64.88889$

$15 \quad 30.29199$

$13 \quad 24.50612$

$\begin{array}{ll}60 & 46.80465\end{array}$

$\begin{array}{ll}563 & 2.184858\end{array}$

$504 \quad 29.96936$

$228 \quad 7.78113$

2,511 313.059

$2,542 \quad 2950512$

$2,913 \quad 0.8295779$

$2891 \quad 1.967145$

$734 \quad 72364.96$

$496 \quad 198563$

$\begin{array}{ll}734 & 74460.07\end{array}$

$\begin{array}{ll}518 & 0.3655386\end{array}$

$\begin{array}{ll}45 & 123499.1\end{array}$

$\begin{array}{ll}53 & 0.4132222\end{array}$

$710 \quad 0.2104577$

$\begin{array}{ll}710 & 0.0707014\end{array}$

$710 \quad 0.1405873$

$\begin{array}{lll}633 & 0.2607362\end{array}$

$720 \quad 2.176986$

$720 \quad 0.9021458$

$720 \quad 2.665278$

$20 \quad 1.231103$

$\begin{array}{ll}720 & 2.390278\end{array}$

$\begin{array}{ll}720 & 1.947925\end{array}$

19.48305

10.80595

2.387926

8.883392

0.7593769

20.80864

8.107164

11654.24

$.49 \mathrm{E}+08$

1.099149

5.34872

241471.8

1013914

241224.4

0.1893375

362575.3

0.1053751

0.2203905

0.150816

0.1687595

0.3890486

2.464302

0.6588027

1.65036

0.7863763

1.448865

1.89249
0.75

0.

0.117733

0.7452409

$0.0953939-0.9738583$

12.88523

68

83.6

38.3

26.5

42

26.2

30.8

53.2

41.2

78.2
.73529

29.6
63.5

$$
63.5
$$

4.583334

99.06905

49.16783

533830.6

$7.50 \mathrm{E}+09$

163.2342

2800000

$1.97 \mathrm{E}+07$

2800000

0.874

1921400

0.663

0.741

0.65

0.65

2.895 
OECD Score for Advance Notice after 20 years

Severance Pay (maximum, in months)

Severance Pay after 9 months, in months

OECD Score for Severance Pay after 9 months

Severance Pay after 4 years, in months

OECD Score for Severance Pay after 4 years

Severance Pay after 20 years, in months

OECD Score for Severance Pay after 20 years

Maximum Severance Pay and Advance Notice Period (sum, in months)

Economic Freedom of the World Index

Government Consumption

Transfers and subsidies

Government enterprises and investment

Top marginal income tax rate

Top marginal income and payroll tax rate

Top marginal tax rate

Size of Government

Judicial independence

Impartial courts

Protection of property rights

Military interference in rule of law and politics

Integrity of the legal system

Legal enforcement of contracts

Regulatory restrictions on the sale of real property

Reliability of police

Business costs of crime

Legal System \& Property Rights

Money growth

Standard deviation of inflation

Inflation: Most recent year

Freedom to own foreign currency bank accounts

Sound Money

Revenue from trade taxes (\% of trade sector)

Mean tariff rate

Standard deviation of tariff rates

Tariffs

Non-tariff trade barriers

Compliance costs of importing and exporting

Regulatory trade barriers

Black market exchange rates

Foreign ownership/investment restrictions

Capital controls

Freedom of foreigners to visit
Aleksynska and Schindler (2011)

Aleksynska and Schindler (2011)

Aleksynska and Schindler (2011)

Aleksynska and Schindler (2011)

Aleksynska and Schindler (2011)

Aleksynska and Schindler (2011)

Aleksynska and Schindler (2011)

Aleksynska and Schindler (2011)

Aleksynska and Schindler (2011)

Fraser Institute

Fraser Institute

Fraser Institute

Fraser Institute

Fraser Institute

Fraser Institute

Fraser Institute

Fraser Institute

Fraser Institute

Fraser Institute

Fraser Institute

Fraser Institute

Fraser Institute

Fraser Institute

Fraser Institute

Fraser Institute

Fraser Institute

Fraser Institute

Fraser Institute

Fraser Institute

Fraser Institute

Fraser Institute

Fraser Institute

Fraser Institute

Fraser Institute

Fraser Institute

Fraser Institute

Fraser Institute

Fraser Institute

Fraser Institute

Fraser Institute

Fraser Institute

Fraser Institute

Fraser Institute $\begin{array}{lll}720 & 1.186111 & 0.9515825\end{array}$

$\begin{array}{lll}720 & 0.5121889 & 0.7492083\end{array}$

$\begin{array}{lll}720 & 1.1 & 1.497703\end{array}$

$\begin{array}{lll}720 & 2.03851 & 1.944117\end{array}$

$\begin{array}{lll}720 & 2.998611 & 2.235445\end{array}$

$\begin{array}{lll}720 & 7.952108 & 9.121698\end{array}$

$\begin{array}{lll}720 & 2.543056 & 2.167103\end{array}$

$\begin{array}{lll}720 & 10.75421 & 9.215702\end{array}$

$\begin{array}{lll}1,947 & 6.757586 & 0.9308023\end{array}$

$\begin{array}{lll}1,947 & 5.876071 & 2.215414\end{array}$

$\begin{array}{lll}1,803 & 7.645657 & 2.132237\end{array}$

$1,920 \quad 6.182292 \quad 3.13482$

$\begin{array}{lll}1,760 & 7.019886 & 2.414461\end{array}$

$\begin{array}{lll}1,613 & 5.109113 & 2.691176\end{array}$

$\begin{array}{lll}1,760 & 6.153409 & 2.374548\end{array}$

$\begin{array}{lll}1,760 & 6.153409 & 2.374548 \\ 1,947 & 6.431382 & 1.324651\end{array}$

$\begin{array}{lll}1,652 & 4.979722 & 2.268244\end{array}$

$\begin{array}{lll}1,945 & 4.694648 & 1.787754\end{array}$

$\begin{array}{lll}1,669 & 5.461732 & 1.920267\end{array}$

$\begin{array}{lll}1,943 & 6.531858 & 2.815312\end{array}$

$\begin{array}{lll}1,741 & 6.27448 & 2.248557\end{array}$

$\begin{array}{lll}1,651 & 4.50252 & 1.780447\end{array}$

$\begin{array}{lll}1.529 & 7.031916 & 2.038656\end{array}$

$\begin{array}{lll}1,192 & 5.470612 & 1.969335\end{array}$

$\begin{array}{lll}1,192 & 5.963398 & 1.896562\end{array}$

$\begin{array}{lll}1,948 & 5.567213 & 1.722691\end{array}$

$\begin{array}{lll}1,945 & 8.314278 & 1.513988\end{array}$

$\begin{array}{lll}1,947 & 8.199702 & 1.988216\end{array}$

$\begin{array}{lll}1,947 & 8.759676 & 1.41208\end{array}$

$\begin{array}{lll}1,947 & 6.481767 & 4.173776\end{array}$

$\begin{array}{lll}1,947 & 7.938711 & 1.536844\end{array}$

$\begin{array}{lll}1,798 & 8.028382 & 2.244456\end{array}$

$\begin{array}{lll}1,914 & 8.118401 & 1.246473\end{array}$

$\begin{array}{lll}1,844 & 5.954631 & 2.138555\end{array}$

$\begin{array}{lll}1,937 & 7.355891 & 1.411506\end{array}$

$\begin{array}{lll}1,657 & 5.893217 & 1.324626\end{array}$

$\begin{array}{lll}1,754 & 7.02329 & 2.130488\end{array}$

$\begin{array}{lll}1,791 & 6.406683 & 1.606725\end{array}$

$\begin{array}{lll}1,943 & 9.711065 & 1.416122\end{array}$

$\begin{array}{lll}1,650 & 6.4882 & 1.440308\end{array}$

$1,932 \quad 3.819281 \quad 3.085556$

$1,319 \quad 4.631736 \quad 3.24231$
5

46.83

10

12

46.83

8.33

9.17

10

10

10

10

10
9.93

9.69

9.69
9.61
10

10

10
10

9.96

9.96

9.55

9.67
9.62

10

9.95

10

10
9.89

10

10

10

10
9.69

10

9.76

10

10

10 
Controls of the movement of capital and people Freedom to trade internationally

Ownership of banks

Private sector credi

Interest rate controls/negative real interest rates)

Credit market regulations

Hiring regulations and minimum wage

Hiring and firing regulations

Centralized collective bargaining

Hours Regulations

Mandated cost of worker dismissal

Conscription

Labor market regulations

Administrative requirements

Bureaucracy costs

Starting a business

Extra payments/bribes/favoritism

Licensing restrictions

Tax compliance

Business regulations

Regulation

Uncoordinated bargaining

Self-regulated bargaining

State-imposed bargaining

Opening clauses exist

mthly_earnings

mthly_earnings (2)

real_mthly_earning

real_mthly_earnings_gr

hw1

hw2wu

hw3wu

hw4wu

hw2wl

hw3wl

hw4wl

hwlus

hw2wuus

hw3wuus

hw4wuus

hw2wlus

hw3wlus

hw4wlus
Fraser Institute

Fraser Institut

Fraser Institute

Fraser Institute

Fraser Institute

Fraser Institute

Fraser Institute

Fraser Institute

Fraser Institute

Fraser Institute

Fraser Institute

Fraser Institute

Fraser Institute

Fraser Institute

Fraser Institute

Fraser Institute

Fraser Institute

Fraser Institute

Fraser Institute

Fraser Institute

Fraser Institute

Visser (2015)

Visser (2015)

Visser (2015)

Visser (2015)

ILO

ILO

ILO

Oostendorp (2012)

Oostendorp (2012)

Oostendorp (2012)

Oostendorp (2012)

Oostendorp (2012)

Oostendorp (2012)

Oostendorp (2012)

Oostendorp (2012)

Oostendorp (2012)

Oostendorp (2012)

Oostendorp (2012)

Oostendorp (2012)

Oostendorp (2012)

Oostendorp (2012)

$\begin{array}{rrrrr}1,949 & 4.77903 & 2.386435 & 0 & 9.63 \\ 1,938 & 7.049438 & 1.270109 & 0 & 9.71 \\ 1,861 & 7.283181 & 3.037734 & 0 & 10 \\ 1,954 & 8.266919 & 2.027851 & 0 & 10 \\ 1,898 & 9.204426 & 1.457296 & 0 & 10 \\ 1,954 & 8.25651 & 1.476298 & 0 & 10 \\ 1,792 & 6.313343 & 2.738943 & 0 & 10 \\ 1,654 & 4.678229 & 1.396341 & 0 & 8.8 \\ 1,655 & 6.455341 & 1.462489 & 1.83 & 9.5 \\ 1,763 & 7.548565 & 1.96474 & 2 & 10 \\ 1,627 & 6.107425 & 3.097659 & 0 & 10 \\ 1,947 & 6.270159 & 4.275813 & 0 & 12 \\ 1,829 & 6.222444 & 1.491114 & 2.29 & 9.73 \\ 1,655 & 3.850785 & 1.351198 & 0.94 & 8.54 \\ 1,636 & 5.017237 & 1.71541 & 0.37 & 9.95 \\ 1,800 & 8.076961 & 1.754555 & 0 & 9.98 \\ 1,655 & 5.599782 & 1.958176 & 1.71 & 9.99 \\ 1,417 & 7.036838 & 2.065103 & 0 & 10 \\ 1,421 & 6.692238 & 2.1914 & 0 & 9.87 \\ 1,791 & 6.024752 & 1.059546 & 2.81 & 8.89 \\ 1,947 & 6.806713 & 1.00628 & 3.45 & 9.32 \\ 3,883 & 0.058975 & 0.2356083 & 0 & 1 \\ 3,883 & 0.0378573 & 0.1908757 & 0 & 1 \\ 3,883 & 0.0185424 & 0.1349194 & 0 & 1 \\ 3,883 & 0.0200876 & 0.1403179 & 0 & 1 \\ 903 & 98259.75 & 353802.2 & 28 & 2843545 \\ 1,563 & 84352.1 & 598973.8 & 0.9 & 1.96 \mathrm{E}+07 \\ 549 & 104346.9 & 469410.6 & -10.3 & 2971366 \\ 710 & 3.042394 & 8.281879 & -26.7 & 142.5 \\ 613 & 1656.624 & 14118.12 & 0.5099457 & 232768.2 \\ 977 & 1219.814 & 11756.65 & 0.5099457 & 232768.2 \\ 1,502 & 1786.593 & 23525.25 & 0.1715439 & 747580.4 \\ 1,502 & 1677.558 & 22213.21 & 0.1715439 & 747580.4 \\ 977 & 1215.562 & 11755.42 & 0.5099457 & 232768.2 \\ 1,502 & 1783.722 & 23524.92 & 0.1715439 & 747580.4 \\ 1,502 & 1673.198 & 22211.62 & 0.1715439 & 747580.4 \\ 603 & 4.608604 & 5.31859 & 0.0744034 & 42.11942 \\ 967 & 4.84367 & 5.487552 & 0.1036705 & 42.26627 \\ 1,491 & 4.778999 & 5.610309 & 0.0484979 & 43.49581 \\ 1,491 & 4.808212 & 5.628498 & 0.0484979 & 42.89057 \\ 967 & 4.843701 & 5.492137 & 0.1036705 & 42.26627 \\ 1,491 & 4.779609 & 5.613838 & 0.0484979 & 43.49581 \\ 1,491 & 4.809273 & 5.634577 & 0.0484979 & 42.89057\end{array}$


Oostendorp (2012)

Oostendorp (2012)

mw4wl

mwlus

Oostendorp (2012)

mw2wuus

Oostendorp (2012)

mw3wuus

mw4wuus

mw2wlus

mw3wlus

mw4wlus

md hw1

md_hw2wu

md_hw3wu

md_hw4wu

md hw2wl

md_hw3wl

md_hw4wl

md_hwlus

md_hw2wuus

md_hw3 wuus

md_hw4wuus

md_hw2wlus

md_hw3wlus

md_hw4wlus

md mw1

md_mw2wu

md_mw $3 w u$

md_mw4wu

md_mw2wl

md_mw3wl

md_mw $4 \mathrm{wl}$

md_mwlus

md_mw2wuus

Oostendorp (2012)

Oostendorp (2012)

Oostendorp (2012)

Oostendorp (2012)

Oostendorp (2012)

Oostendorp (2012)

Oostendorp (2012)

Oostendorp (2012)

Oostendorp (2012)

Oostendorp (2012)

Oostendorp (2012)

Oostendorp (2012)

Oostendorp (2012)

Oostendorp (2012)

Oostendorp (2012)

Oostendorp (2012)

Oostendorp (2012)

Oostendorp (2012)

Oostendorp (2012)

Oostendorp (2012)

Oostendorp (2012)

Oostendorp (2012)

Oostendorp (2012)

Oostendorp (2012)

Oostendorp (2012)

Oostendorp (2012)

Oostendorp (2012)

Oostendorp (2012)

md mw3wuus

stendorp (2012)

md_mw4wuus

md_mw2wlus

md_mw 3 wlus

Oostendorp (2012)

Oostendorp (2012)

Oostendorp (2012)

$\begin{array}{rrrrr}583 & 282914.7 & 2234794 & 113 & 3.53 \mathrm{E}+07 \\ 863 & 221859.2 & 1932516 & 117.6571 & 3.53 \mathrm{E}+07 \\ 1,502 & 307736.4 & 4240226 & 32.59444 & 1.41 \mathrm{E}+08 \\ 1,502 & 295245.6 & 4105344 & 32.59444 & 1.41 \mathrm{E}+08 \\ 863 & 221124 & 1931974 & 117.6571 & 3.53 \mathrm{E}+07 \\ 1,502 & 307289.5 & 4240093 & 32.59444 & 1.41 \mathrm{E}+08 \\ 1,502 & 294322.6 & 4104919 & 32.59444 & 1.41 \mathrm{E}+08 \\ 573 & 770.2967 & 844.4178 & 14.50867 & 6908.289 \\ 853 & 863.7754 & 933.6207 & 17.57289 & 7077.58 \\ 1,491 & 809.5412 & 922.5118 & 8.324871 & 7130.436 \\ 1,491 & 816.6473 & 927.8441 & 8.324871 & 7022.349 \\ 853 & 864.1552 & 935.2452 & 17.57289 & 7077.58 \\ 1,491 & 810.1505 & 923.516 & 8.324871 & 7130.436 \\ 1,491 & 816.5872 & 927.7655 & 8.324871 & 7022.349 \\ 613 & 1383.05 & 10220.42 & 0.4108009 & 157642.8 \\ 977 & 1025.725 & 8780.809 & 0.4108009 & 157642.8 \\ 1,502 & 1524.332 & 20569.66 & 0.1486813 & 669496.9 \\ 1,502 & 1414.345 & 19549.24 & 0.1522623 & 669496.9 \\ 977 & 1022.946 & 8776.876 & 0.4108009 & 157642.8 \\ 1,502 & 1522.422 & 20568.61 & 0.1486813 & 669496.9 \\ 1,502 & 1411.158 & 19547.75 & 0.1522623 & 669496.9 \\ 603 & 4.084803 & 4.733617 & 0.0744034 & 33.13198 \\ 967 & 4.244063 & 4.989307 & 0.0855963 & 39.14506 \\ 1,491 & 4.167396 & 5.081697 & 0.0390021 & 39.14506 \\ 1,491 & 4.20639 & 5.128844 & 0.0390021 & 38.3528 \\ 967 & 4.245791 & 4.994568 & 0.0855963 & 39.14506 \\ 1,491 & 4.168758 & 5.085328 & 0.0390021 & 39.14506 \\ 1,491 & 4.207091 & 5.132452 & 0.0390021 & 38.3528 \\ 583 & 242394.3 & 1679230 & 53.94501 & 2.46 \mathrm{E}+07 \\ 863 & 190478.8 & 1492309 & 53.94501 & 2.46 \mathrm{E}+07 \\ 1,502 & 269972.6 & 3779816 & 24.7662 & 1.26 \mathrm{E}+08 \\ 1,502 & 254814.2 & 3645761 & 27.07795 & 1.26 \mathrm{E}+08 \\ 863 & 190120.3 & 1491554 & 53.94501 & 2.46 \mathrm{E}+07 \\ 1,502 & 269739 & 3779649 & 24.18326 & 1.26 \mathrm{E}+08 \\ 1,502 & 254282 & 3645513 & 24.38 & 1.26 \mathrm{E}+08 \\ 573 & 692.5191 & 766.3384 & 14.50867 & 5620.823 \\ 853 & 765.8381 & 851.5082 & 16.35635 & 6505.294 \\ 1,491 & 714.457 & 843.21 & 6.725221 & 6505.294 \\ 1,491 & 723.2622 & 853.9547 & 6.725221 & 6178.354 \\ 853 & 765.8444 & 851.5212 & 16.35635 & 6505.294 \\ 1,491 & 714.8902 & 843.4365 & 6.725221 & 6505.294 \\ 1,491 & 723.4565 & 854.0366 & 6.725221 & 6178.354\end{array}$

